Portland State University

PDXScholar

\title{
A stratigraphic-geochemical study of the Troutdale Formation and Sandy River Mudstone in the Portland basin and lower Columbia River Gorge
}

Rodney Duane Swanson

Portland State University

Follow this and additional works at: https://pdxscholar.library.pdx.edu/open_access_etds

Part of the Geochemistry Commons, Geology Commons, and the Stratigraphy Commons Let us know how access to this document benefits you.

\section{Recommended Citation}

Swanson, Rodney Duane, "A stratigraphic-geochemical study of the Troutdale Formation and Sandy River Mudstone in the Portland basin and lower Columbia River Gorge" (1986). Dissertations and Theses. Paper 3720.

https://doi.org/10.15760/etd.5604

This Thesis is brought to you for free and open access. It has been accepted for inclusion in Dissertations and Theses by an authorized administrator of PDXScholar. Please contact us if we can make this document more accessible: pdxscholar@pdx.edu. 
AN ABSTRACT FOR THE THESIS OF Rodney Duane Swanson for the Masters of Science in Geology presented October 20, 1986

Title: A Stratigraphic-Geochemical Study of the Troutdale Formation and Sandy River Mudstone in the Portland Basin and Lower Columbia River Gorge.

APPROVED BY THE MEMBERS OF THE THESIS COMMITTEE:
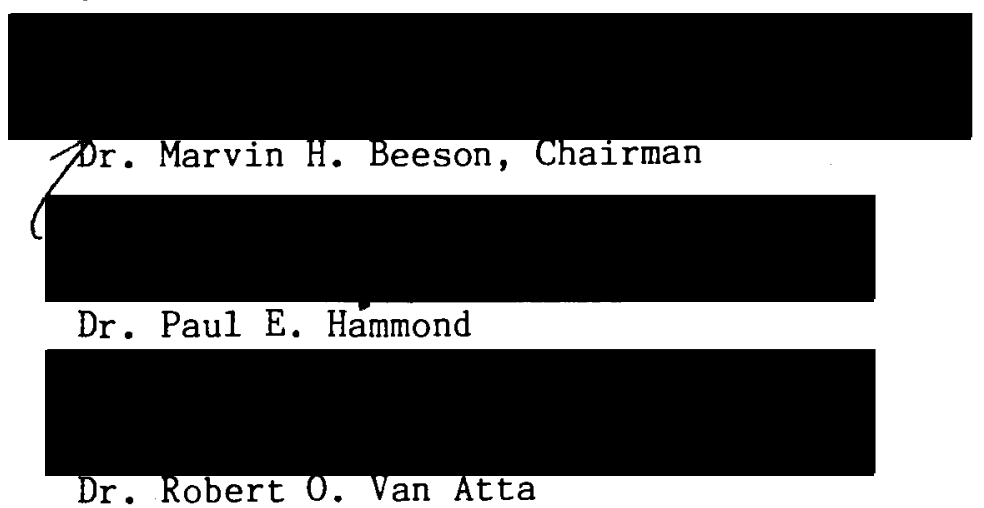

Hyaloclastic sediment forms an identifiable stratigraphic interval within the Troutdale Formation that can be traced from the Bridal Veil channel to the Portland basin. Hyaloclastic sediment composed chiefly vitric sands is found interbedded with muds, sandy muds and gravels penetrated by wells in northeast Portland are correlated with the upper member of the Troutdale Formation. These beds are characteristic of the informal upper member of the Troutdale Formation in the Bridal Veil channel of the ancestral Columbia River (Tolan and Beeson, 1984) and the type area of the Troutdale Formation exposed along the Sandy River (Trimble, 1963). Fluvially deposited 
hyaloclastic beds within the upper Troutdale Formation are interpreted to be the result of interaction of Cascadian basaltic lavas with an ancestral Columbia River (Tolan and Beeson, 1984; Trimble, 1963). Glass clasts taken from well and outcrop samples have nearly identical trace and minor element geochemical content as determined by instrumental neutron activation analysis.

Based on similar major oxide geochemical content (Wise, 1969; Tolan and Beeson, 1984), the upper member Troutdale Formation hyaloclastic sediment is derived from Pliocene (5-2 m.y.b.p.) High Cascades high-alumina basalts found between the Hood River Valley and the Bull Run area. Trace and minor element data for High Cascade Group basalts along the Washington side of the Columbia River area (Hammond and Korosec, 1983) show a similarity between basalts near Underwood Mountain and hyaloclastic separates. Vitric material from a gravel 100 meters below the main body of upper Troutdale Formation hyaloclastic sediment is tentatively correlated with basalts of the Simcoe Volcanics in south-central Washington based on major oxide content (James Anderson, 1985 written communication). Age dates for the Simcoe basalts range from 2(?)-7.5 m.y.b.p. (James Anderson, 1985 written communication). The latest Pliocene and early Pleistocene Boring Lavas, K-Ar age dated at 1.3 (Edwin H. McKee and Norman S. MacLeod, 1985 written communication) and 2.5 m.y.b.p. (Robert H. Duncan and Norman S. MacLeod, 1985 written communication) that intrude and overlie the Troutdale Formation in the Portland area are not source rocks for Portland area Troutdale Formation hyaloclastites based on differing trace and minor element concenatrations. 
In the Portland basin hyaloclastic beds are interbedded with intervals of non-hyaloclastic sediment. Upper Troutdale Formation exposed in the lower Columbia River Gorge is dominated by hyaloclastic sands and gravels. In the Portland Basin up to 900 feet of Troutdale Formation basaltic gravel overlies the hyaloclastic interval which defines the base of the upper Troutdale Formation.

Trace element contents of Sandy River Mudstone and lower Troutdale Formation sediment are similar. Addition of High Cascades lava-derived sediment to the upper Troutdale Formation is indicated by higher $\mathrm{Cr}$, Co, Fe and Sc concentratons. Q-F-L plots show a similarity between the Sandy River Mudstone and the lower Troutdale Formation and a higher amount of lithic material in upper Troutdale Formation sediments in the well area. Modern lower Columbia River sediment (Whetten and others, 1969) plots within the range of the upper and lower Troutdale Formation in a Q-F-L Plot.

Formation of the Portland basin was in progress at the time of Columbia River basalt deposition (Beeson and others, 1984). Deformation probably continued through deposition of the post-Columbia River basalt Pliocene sediment in the basin. Along the eastern margin of the Portland Basin the Troutdale Formation appears to be gently dipping toward the west. Locally however, upper Troutdale Formation hyaloclastic sediment is offset approximately 150 metres downward from Prune Hill, Washington to the Blue Lake area, two miles to the southwest, on the on the Oregon bank of the Columbia River. 
A STRATIGRAPHIC-GEOCHEMICAL STUDY OF THE TROUTDALE FORMATION AND SANDY RIVER MUDSTONE IN THE PORTLAND BASIN AND LOWER COLUMBIA RIVER GORGE

by

RODNEY DUANE SWANSON

A thesis submitted in partial fulfillment of the requirements for the degree of

MASTER OF SCIENCE

in

GEOLOGY

Portland State University

1986 
TO THE OFFICE OF GRADUATE STUDIES AND RESEARCH:

The members of the Committee approve the thesis of Rodney Duane Swanson presented October 20, 1986.

Marvin H. Beeson, Chairman

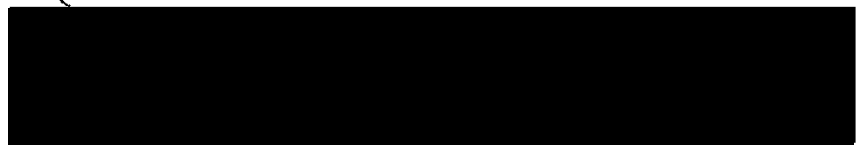

Paul E. Hammond

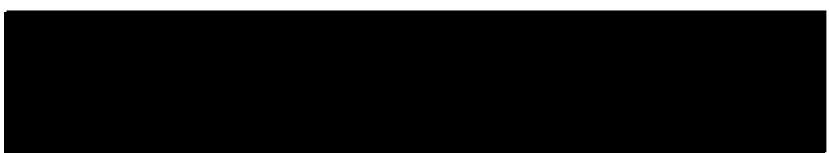

Robert 0. Van Atta

APPROVED:
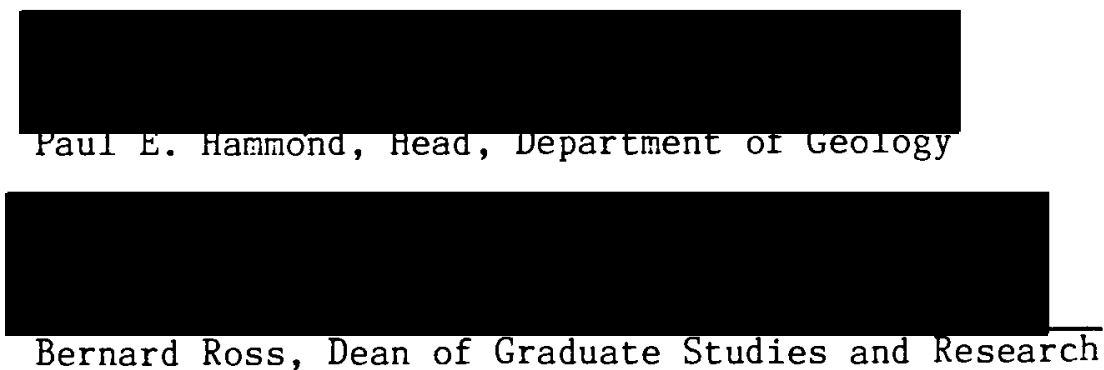


\section{ACKNOWLEDGEMENTS}

This work was funded by a grant from the City of Portland Bureau of Waterworks. Drill cuttings and other materials made available by the Portland Water Bureau enabled this study.

I also thank my advisor, Dr. Marvin H. Beeson, for his assistance, insight and attempted deadlines. Doctors Paul E. Hammond and Robert 0. Van Atta critically read the thesis and offered suggestions that improved the thesis text. Dr. Hammond also contributed much time to discussion of the study. I also thank Susan Hartford for proofreading my thesis several times. 
TABLE OF CONTENTS

PAGE

ACKNOWLEDGEMENTS . . . . . . . . . . . . . . iii

LIST OF TABLES ...................... . . . . vi

LIST OF FIGURES. . . . . . . . . . . . . . vii vi

PLATES ..................... back

CHAPTER

I INTRODUCTION

General and Purpose............ . 1

Background Geology............. . 5

Geochemical Analysis. .......... 15

II NON-HYALOCLASTIC SEDIMENTARY ROCKS OF THE SANDY RIVER MUDSTONE AND TROUTDALE FORMATION

Lithology . . . . . . . . . . . . 17

Petrographic Line Counts. . . . . . . . 19

Sediment Geochemistry . . . . . . . . 22

III VITRIC BEDS AND THEIR USE AS STRATIGRAPHIC MARKERS

General .............. 30

Hyaloclastite Lithology. . . . . . . . 31

Hyaloclastite Petrography. ......... 32

Hyaloclastite Geochemical Data. . . . . . . 33

Discussion of Geochemical Data. ....... 39 
IV HIGH-ALUMINA BASALTS AND THEIR RELATION TO HYALOCLASTTTES

General ................. . . 41

Geochemical Correlation . . . . . . . . . 44

V STRUCTURAL DEFORMATION OF THE TROUTDALE FORMATION. • • 57

VI LATE CENOZOIC HISTORY OF THE PORTLAND BASIN. • . . . . 66

VII SUMMARY AND CONCLUSIONS. • • • • • • . • • . . 70

REFERENCES CITED . . . . . . . . . . . . . . . . . . 74

APPENDICES

A INAA SAMPLE TYPE, FORMATION AND LOCATION . . . . . . 80

B INAA GEOCHEMICAL DATA. . . . . . . . . . . . 83

C CROSS-SECTIONS SHOWING HYALOCLASTITE UNITS IN THE WELL AREA. . . . . . . . . . . . . . 100 


\section{LIST OF TABLES}

TABLE

PAGE

I Sediment line count results . . . . . . . . . 20

II Trace and minor element geochemistry of vitric and

lithic sediments, and lavas ........ 35-36

III Major oxide geochemistry of vitric samples. . . . . . . 37 


\section{LIST OF FIGURES}

FIGURE

PAGE

1. Location of Portland Water Bureau exploratory wells sampled . . . . . . . . . . . . . . . 3

2. Geographic reference map for study area . . . . . . . 4

3. General stratigraphic column for the Portland area and lower Columbia River Gorge. . . . . . . . . .

4. Generalized stratigraphy of the Troutdale Formation exposed along the Sandy River . . . . . . . . 8

5. Diagramatic cross-section of the Bridal Veil channel. •

6. Geologic, hyaloclastic and hydrogeologic units of the well area . . . . . . . . . . . . . . .

7. Classification of sandstones from the upper and lower Troutdale Formation and the Sandy River Mudstone compared with modern sediment . . . . . . . . .

8. Volcanic and non-volcanic bedrock geology of the modern Columbia River system. . . . . . . . . .

9. Scandium versus cobalt graph for non-hyaloclastic sediments and vitric material, experiment 7T. . . .

10. Scandium versus cobalt graph for sediments and vitric naterial, experiment 7 H. . . . . . . . . .

11. Lanthanum versus thorium for sediments from the upper and lower Troutdale Formation and Sandy River Mudstone. . . . . . . . . . . . . . . . . 
12. Graph of chromium versus lanthanum/samarium for vitric separates, and whole hyaloclastites and 1ithic sands . . . . . . . . . . . . . . . . . .

13. Stratigraphic section of the Mount Hood area. . . . .

14. Wel1 area Troutdale Formation hyaloclastites and their source volcanics along the Columbia River . . .

15. Lanthanum/samarium versus cobalt graph for Troutdale Formation vitric separates and Boring Lavas . . . . . 48

16. Lanthanum/samarium versus cobalt graph for Troutdale Formation vitric separates and Columbia River Gorge area high-alumina lavas . . . . . . . . . . .

17. Lanthanum/samarium versus lanthanum graph for Boring Lavas of the Portland area, high-alumina basalts of the lower Columbia River Gorge area, and vitric separates . . • . . . . . . . . . • . . . .

18. $\mathrm{FeO} * / \mathrm{MgO}$ versus $\mathrm{SiO}_{2}$ graph with vitric separates compared with High Cascades lavas . . . . . . . .

19. $\mathrm{TiO}_{2}$ versus $\mathrm{P}_{2} \mathrm{O}_{5}$ graph comparing vitric to High Cascades basalts Simcoe volcanics basalts . . . . .

20. Distribution of the Troutdale Formation in the lower Columbia River Gorge. . . . . . . . . . . . .

21. The elevation of the Sandy River Mudstone-Troutdale Formation contact as mapped by Trimble (1963) . . . .

22. Diagramatic cross-section west-east from the eastern margin of the well area to the Sandy River. . . . . . 
23. Diagramatic cross-section S-SW to $\mathrm{N}-\mathrm{NE}$ between the well area and Lackamas Lake . . . . . . . . 63

24. Location of cross-sections in Appendix C. . . . . . 100 
CHAPTER I

INTRODUCTION

Genera1 and Purpose

Numerous geologic studies of the Portland and lower Columbia River Gorge areas include examinations of the sediments included in the Troutdale Formation and Sandy River Mudstone. The earliest studies (Bretz, 1917; Williams, 1916; Hodge, 1938; Treasher, 1942) grouped the current Troutdale Formation and Sandy River Mudstone together as postColumbia River basalt sediment. Later workers (Trimble, 1963; Mundorff, 1964) divided the Troutdale Formation into two separate stratigraphic units. The more widely recognized nomenclature is Trimble's (1963) separation of the fine-grained lower portion of the Troutdale Formation into the Sandy River Mudstone. The Troutdale Formation and Sandy River Mudstone were still described as stratigraphically undifferentiable masses of sediment, deposited by some sort of ancestral Columbia River and local streams. Tolan and Beeson (1984) further refined the stratigraphy of the Troutdale Formation in the lower Columbia River Gorge by defining upper and lower members of an ancestral Columbia River facies. Their informal upper and lower members are based on the upward transition from deposits of non-locally-derived gravels of the Columbia River drainage to sediment dominated by hyaloclastic debris and basalt cobbles derived from High Cascades lavas.

This study examines the hyaloclastic sediment that is in part 
definitive of Tolan and Beeson's (1984) upper member Troutdale Formation. Sediment included in the lower member of the Troutdale Formation and the Sandy River Mudstone is examined in order to further define the statigraphic relationships within these units in the Portland area. Fluvial hyaloclastites, also referred to as vitric sands (Trimble, 1963), in the upper member of the Troutdale Formation are studied as potential stratigraphic marker beds based on minor and trace element content and lithology. Basaltic glass (sideromelane) clasts from hyaloclastites are analyzed in an attempt to correlate them with possible Cascadian eruptive sources.

Within the City of Portland the Troutdale Formation hyaloclastic sediment is found in wells drilled for the Portland Water Bureau (Willis, 1977; Hoffstetter, 1984). Well cuttings, lithologic logs, and geophysical logs used in this study are from wells drilled by the Portland Water Bureau Exploratory Well Project (Willis, 1977). The deepest and most widely distributed wells were drilled for the Portland Water Bureau as a part of the Exploratory Well Project (Figure 1). Selected cuttings from five of these wells were sampled, examined and analyzed. Stratigraphic sections were measured and sampled near the type area of the Troutdale Formation and Sandy River Mudstone along the Sandy River (Hodge, 1938, Trimble, 1963). The reference section for the upper and lower members of the Troutdale Formation at Bridal Veil, Oregon (Tolan and Beeson, 1984) was also measured and sampled. Figure 2 shows locations of samples and measured sections.

Geologic Background

Sediment studied in this report is interpreted to be younger than 


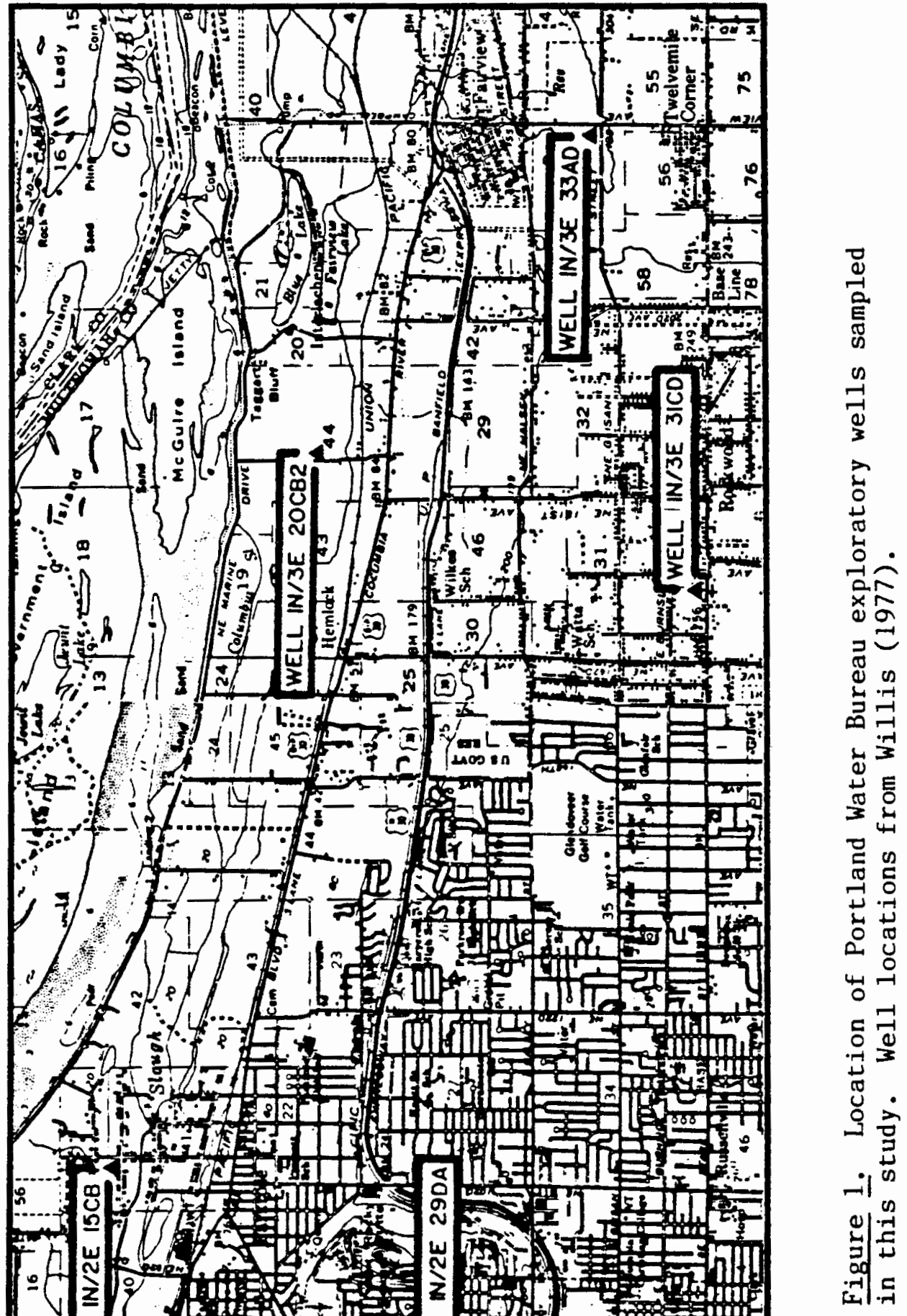




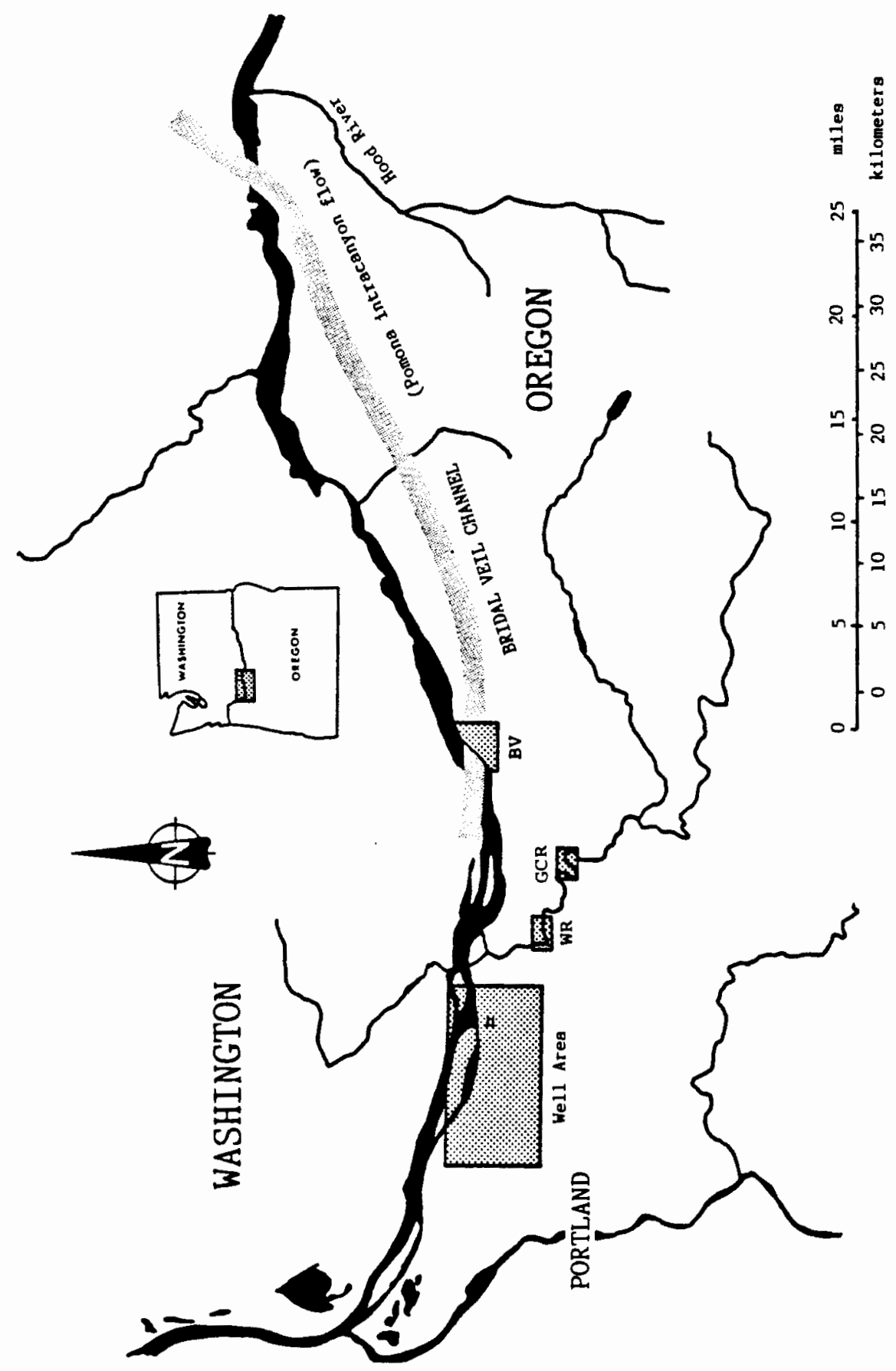

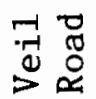

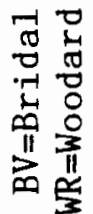

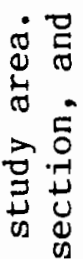

눈

응

空

\&

¿

돈

4

บ II

몸엉

\%

잉

过

U

Ni

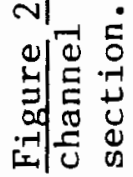


the lava flows of the middle Miocene Columbia River Basalt Group in western Oregon based on their stratigraphic position overlying the Columbia River basalts in the lower Columbia River Gorge (Tolan and Beeson, 1984; Hodge, 1938) and in the Portland basin (Trimb1e, 1963). The Columbia River Basalt Group overlies the upper Eocene to Miocene Skamania Volcanics and the Oligocene to lower Miocene Eagle Creek Formation east of Portland in the lower Columbia River Gorge. West of the Portland area, middle Miocene Scappoose Formation and older Eocene, Oligocene and lower Miocene marine sediments of the Yamhill Formation, Cowlitz Formation, Keasey Formation and Pittsburg Bluff Formation along with the Eocene basalts of the Tillamook Volcanics predate the Columbia River basa1t (Newton, 1969; Hammond, 1979; Kadri, 1982; Van Atta and Kelty, 1985). In the Cascade Range west of Mount Hood, the middle to upper Miocene Rhododendron Formation interfingers with and overlies flows of the Columbia River Basalt Group (Priest and others, 1982). The Sandy River Mudstone and Troutdale Formation overlie mudflows of the Rhododendron Formation in the valleys of the Sandy River and Clackamas River (Allen, 1932; Trimble, 1963; Peck and others, 1964). Figure 3 depicts the general Cenozoic stratigraphy in the Portland area and lower Columbia River Gorge.

The Troutdale Formation was named by Hodge (1938) for thick beds of gravels and sands exposed as cliffs along the Sandy River near the town of Troutdale, Oregon. Here, the Troutdale Formation is composed of coarse, fluvially-deposited hyaloclastites, quartzite-bearing gravels, lenses of micaceous arkose, and lithic sands (Trimble, 1963). Trimble (1963) determined that the hyaloclastites are composed of 


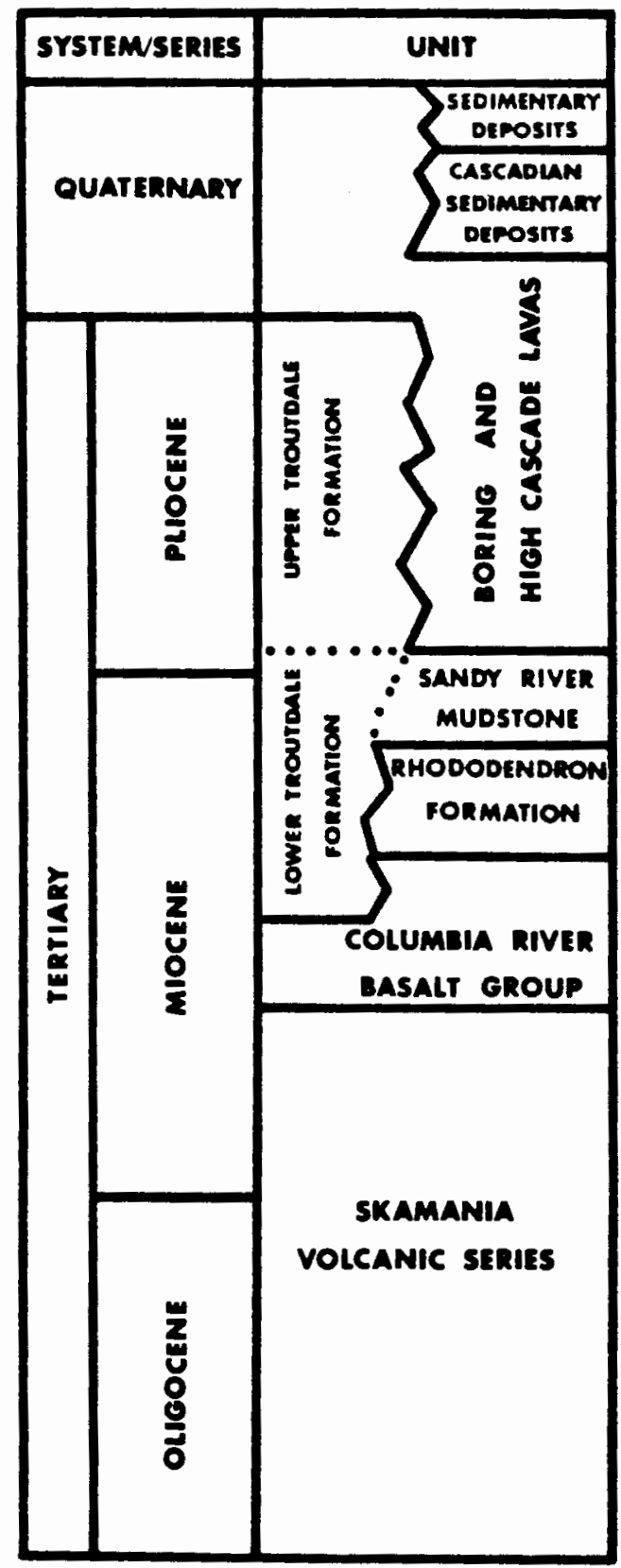

Figure 3. General stratigraphic column for the Portland area and lower Columbia River Gorge. Modified from Tolan and Beeson (1984), Trimble (1963), and Anderson (1980). 
sideromelane (basaltic glass) sand based on refractive index and attributed their formation to the interaction of basalt tlows and a river flowing through the Cascades. Figure 4 is a generalized stratigraphic section for the type locality of the Troutdale Formation along the Sandy River taken from Trimble (1963). Trimble (1963) noted that beneath the gravels are beds of mud and sandy mud, possibly of lacustrine origin, and renamed this portion of Hodge's Troutdale Formation the Sandy River Mudstone. The Sandy River Mudstone and Troutdale Formation extend westward into the Portland Basin where they are presumed to overlie Columbia River basalt based on a driller's log from the Ladd well near NE 39th and Glisan (circa 1885) and other wells drilled near the margins of the basin (Trimble, 1963).

Fossil flora found in the Sandy River Mudstone near the transition from the Sandy River Mudstone to the Troutdale Formation in the Sandy River area establish an age of early Pliocene (Chaney, 1944 in Trimble, 1963 p.35). In the Portland area upper Pliocene to lower Pleistocene Boring Lavas intrude and overlie the Troutdale Formation unconformably (Treasher, 1942; Trimble, 1963; Beeson and Nelson, 1978). A potassium-argon age date of $1.3 \mathrm{~m} . \mathrm{y} . \mathrm{b} . \mathrm{p}$. has been determined for Boring Lavas from Rocky Butte in northeast Portland (Edwin McKee and Norman Macleod, 1985 unpublished date, written communication). A somewhat older age of $2.6 \mathrm{~m} . \mathrm{y} . \mathrm{b} . \mathrm{p}$. is found for Boring Lavas of the Oregon City plateau (Robert Duncan and Norman MacLeod, 1985 unpublished potassium-argon age date, written communication).

Tolan and Beeson (1984), in their work with Columbia River Basalt Group stratigraphy of the Columbia River Gorge interpreted a thick 


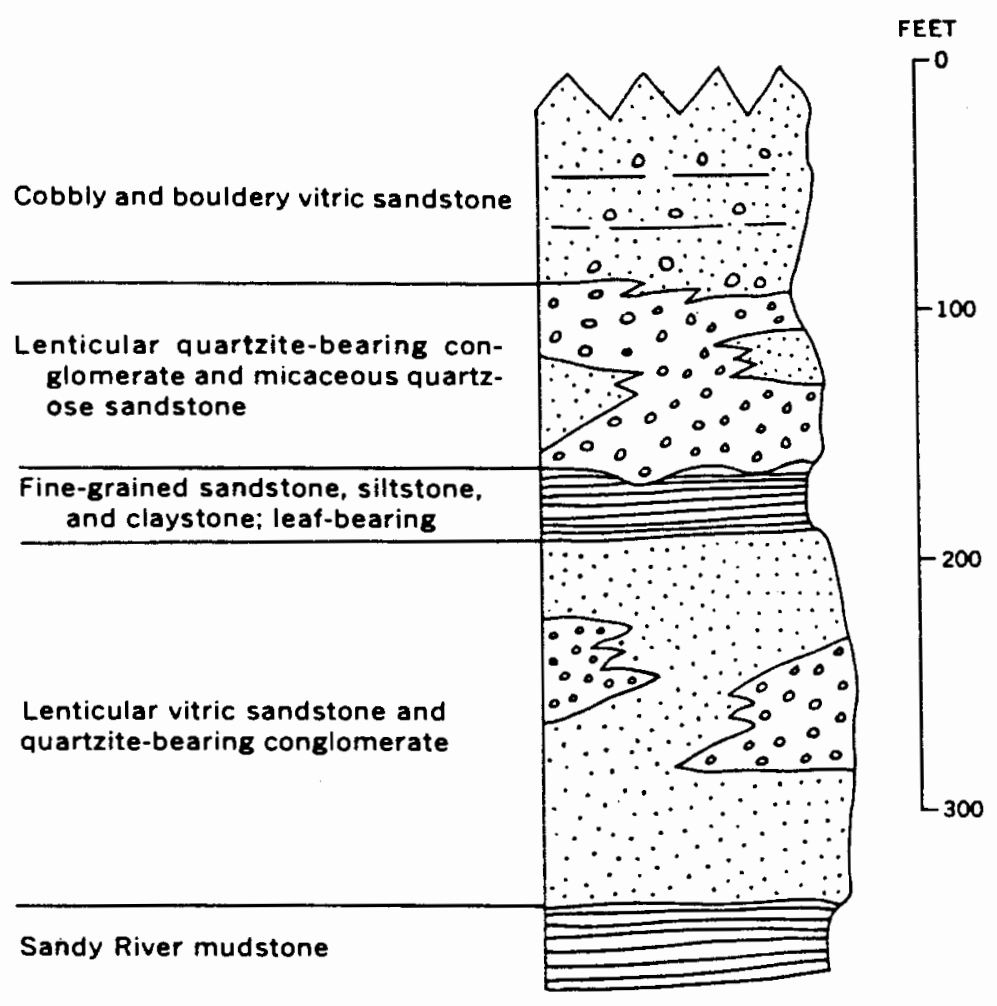

Figure 4. Generalized stratigraphy of the Troutdale Formation exposed along the Sandy River between Troutdale and Gordon Creek. From Trimble (1963).

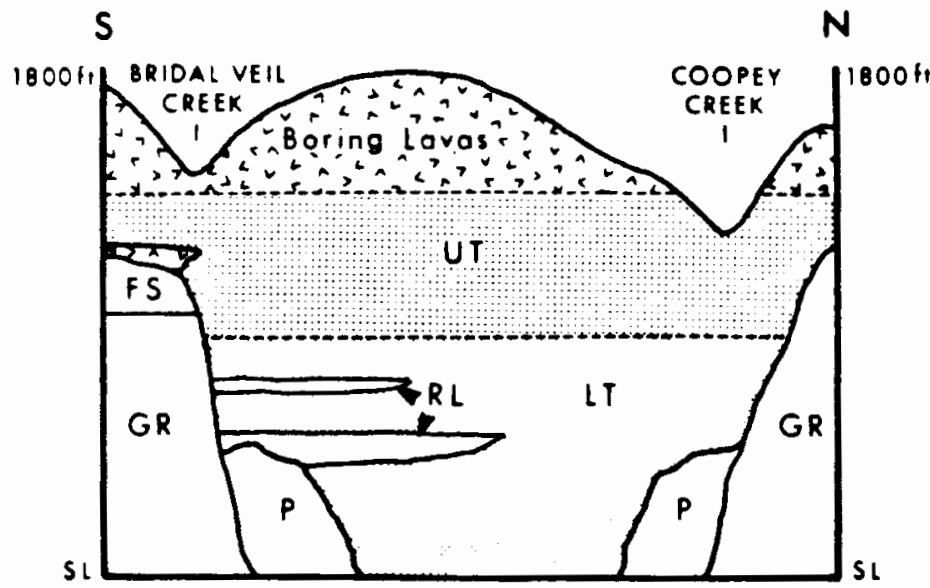

Figure 5. Diagramatic cross-section of the Bridal Veil channel at Bridal Veil, Oregon. From Tolan and Beeson (1984). Stratigraphic units: $\quad G R=$ Grande Ronde Basalt, $F S=$ Frenchman Springs Basalt, $P=P o m o n a$ Basalt, RL=Rhododendron lahar, LT=lower Troutdale member, UT=upper Troutdale member. 
(approximately 1000 feet) section of Troutdale Formation gravels, sands and coarse conglomerates near the town of Bridal Veil, Oregon to be paleochannel sediment filling a canyon cut into the Columbia River basalts by an ancestral Columbia River. This was named the Bridal Veil channel (Figure 2). Tolan and Beeson (1984) divided the Bridal Veil channe] section of the Troutdale Formation into informal upper and lower members based on the stratigraphic succession of two distinct lithologic facies: A lower member characterized by quartzite-bearing basaltic gravel and micaceous arkoses, and an upper member characterized by fluvially deposited hyaloclastite, lithic sand, basaltic gravel, and conglomerate (Figure 5).

The presence of quartzite and other non-Cascadian clasts in the Troutdale Formation gravels has led several authors (Williams, 1916; Lowry and Baldwin, 1952; Trimble, 1963) to speculate that at least part of the sediment contributed to the Troutdale Formation is derived from rocks outside the northwest Oregon region. Tolan and Beeson (1984) interpreted that their lower member of the Troutdale Formation was deposited by an ancestral Columbia River which was in existence since at least the late middle Miocene. Although other gravels included in the Troutdale Formation have been found as interbeds and channel fills within the Columbia River basalts in the lower Columbia River Gorge and western Oregon, no other gravels appear to be as thick or widespread as the post-Columbia River Basalt Group Troutdale Formation (Anderson, 1978, 1980; Beeson and others, 1985).

The transition from the lower member to the upper member of the Troutdale Formation is interpreted to be the result of the onset of 
High Cascade high-alumina basaltic volcanism and its interaction with the ancestral Columbia River (Tolan and Beeson, 1984). Hyaloclastic debris formed when the lavas flowed into the ancestral Columbia River. Fluvial deposits of this hyaloclastic debris, along with High Cascade basalt cobbles, characterize the sedimentary rocks of the upper member of the Troutdale Formation (Tolan and Beeson, 1984). Chemical analysis of sediments of the upper member of the Troutdale Formation in this study shows that much of this material is derived from high-alumina basalts of the High Cascades.

Filling of the Bridal Veil canyon with hyaloclastites, basaltic gravels and conglonerates allowed the ancestral Columbia River to move laterally and deposit sediment over a wider area. The Bridal Veil section is capped by high-alumina basalts of the High Cascades (Tolan and Beeson, 1984). These basalts are correlative with the Boring Lavas of the Portland area (Allen, 1975; Peck and others, 1964; Wise, 1969; Priest, 1982) and have been grouped together with the Boring Lavas of the Portland area based on major oxide geochenistry (Tolan and Beeson, 1984).

Some time constraints have been placed on the deposition of the Troutdale Formation in the Bridal Veil channel. The sediment in the channel is assumed to be younger than $12 \mathrm{~m} . \mathrm{y} . \mathrm{b} . \mathrm{p}$. because the Troutdale Formation fills a canyon cut into the $12 \mathrm{~m} . \mathrm{y}$. old Pomona Member of the Saddle Mountains Basalt, Columbia River Basalt Group (Tolan and Beeson, 1984). Two laharic mudflows are interbedded within the lower member of the Troutdale Formation approximately 300 feet to 450 feet below the lowest exposure of upper member sediment. These lahars were correlated 
with the Rhododendron Formation. Lahar clasts were found to be geochemically similar to a microdiorite that intrudes the lower Rhododendron Formation in the 01d Maid Flat area west of Mount Hood and lithologically similar to a dacite flow near Lolo Pass northwest of Mount Hood which has been $\mathrm{K}-\mathrm{Ar}$ dated at 9 to $10 \mathrm{~m} \cdot \mathrm{y} \cdot \mathrm{b} \cdot \mathrm{p}$. (Tolan and Beeson, 1984; Priest and others, 1982).

The transition from lower to upper member Troutdale Formation is assumed to have taken place in early Pliocene time (Tolan and Beeson, 1984). At this time high-alumina basaltic eruptions were occurring in the Mount Hood area as well as throughout the Cascades (Hammond, 1979; Wise, 1969; White and McBirney, 1978). Capping of the Troutdale Formation by high-alumina basalts or Boring Lava equivalent, along with uplift in the Cascades, ended the accumulation of sediment along the ancestral Columbia River in the western Cascade Range. An approximate date of $2 \mathrm{~m} . \mathrm{y} \cdot \mathrm{b} . \mathrm{p}$. has been suggested as a minimum age for upper member deposition based on a $\mathrm{K}-\mathrm{Ar}$ age date from a high-alumina lava flow overlying upper member Troutdale Formation in the lower Columbia River Gorge (Tolan and Beeson, 1984).

Treasher (1942) identified weathered lithic sands, gravels and bouldery conglomerates southeast of Portland as part of the Troutdale Formation based on their degree of weathering and similarity to the coarse uppermost Troutdale Formation along the Sandy River and lower Columbia River Gorge. Trimble (1963) separated this apron-1ike sheet of weathered mudflows and gravels from the Troutdale Formation because of their 1ithology, position above flows of Boring Lava, and apparent unconformable contact with the quartzite-pebble-bearing Troutdale 
Formation. The Springwater and Walters Hill Formations were created to include these deposits (Trimble, 1963). Other Pleistocene deposits are associated with the drainages of existing rivers such as the Sandy and Clackamas near the southeast margin of the Portland Basin (Trimble, 1963). Pleistocene flood deposits, and older Pleistocene sands, gravels and muds derived from the Columbia River drainage system cover much of the greater Portland area (Trimble, 1963).

Strata penetrated during well drilling by the Portland Water Bureau contain numerous fluvially deposited hyaloclastites or basaltic glass sands (also referred to as vitric sands), and sediment rich in basaltic glass (Hoffstetter, 1984; Willis, 1977). Hydrogeologic units informally named by Hoffstetter (1984) that contain hyaloclastites and vitric-rich beds are the Parkrose aquitard, Troutdale Sand aquifer, Rose City, aquifer and Rose City aquitard (Figure 6a). Hyaloclastites are exposed at the surface near Blue Lake and vitric material is found in drill cuttings to an elevation of -925 feet in well 1N/2E $29 \mathrm{DA}$. Four well area hyaloclastite units were given abbreviated names (Figure 6b) based on informal aquifer and aquitard names of Hoffstetter (1984). The four units from lower to upper are: The lower Rose City aquifer hyaloclastite units (LRC), the Rose City aquifer hyaloclastite units (RC), the Troutdale Sand aquifer units (TSA), and the Upper Troutdale Sand aquifer units (UTSA).

The TSA and RC hyaloclastite units contain the bulk of the vitric material deposited in the well area. The RC, TSA and UTSA vitric sand beds in the well area are correlative with the upper member of the Troutdale Formation. The basaltic glass-bearing sand LRC is within 
Figure $6 \mathrm{~b}$.

EXPLORATORY WELL IN/2E $15 C B$

(1) N. E. WSIT ANENUE a HOLMAN STREET

Figure $6 a$.
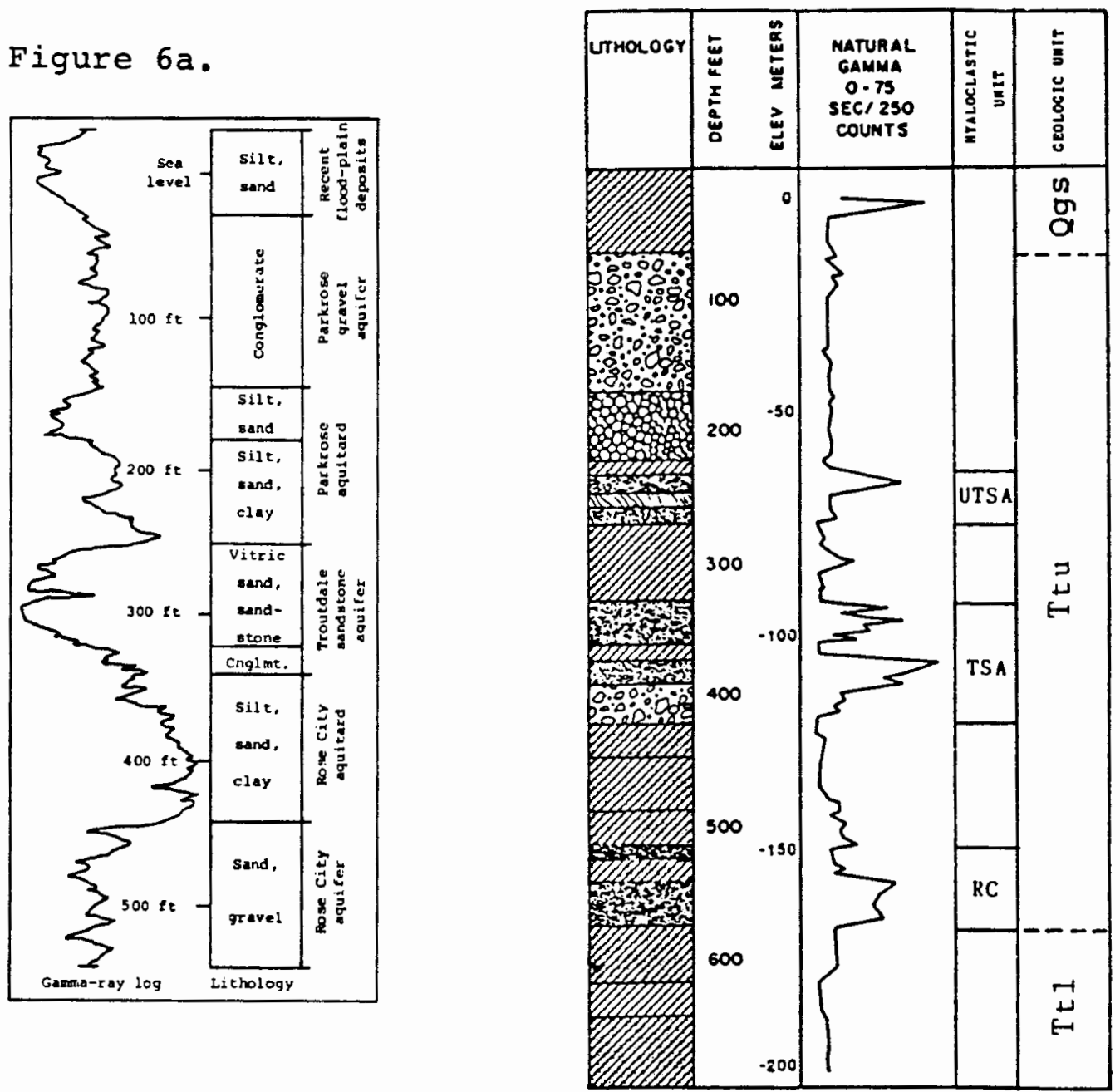

Figure 6. Geologic, hyaloclastic and hydrogeologic units of the well area. Figure 6a, from Hoffstetter (1984), shows the hydrogeologic units of the Portland Well Field. Figure $6 \mathrm{~b}$ is the geologic and hyaloclastic units defined and described in this study (modified from Willis, 1977). Tt1=lower member Troutdale, Ttu=upper member Troutdale, Qgs=Quaternary gravels and sands, RC=Rose City hyaloclastic unit, TSA=Troutdale sandstone hyaloclastic unit, UTSA=upper Troutdale sandstone hyaloclastic unit. Not shown, LRC lower Rose City hyaloclastic unit 250 feet below upper Troutdale base in well 1N/2E 29DA. 
lower Troutdale Formation equivalent sediment and is distinct in source from the upper Troutdale hyaloclastic beds (RC, TSA and UTSA).

Hyaloclastic debris forms as lava advances into a body of water or is erupted beneath water. Glass is formed by rapid chilling of lava. In cases where lava flows into standing water such as a lake, water trapped by advancing flow lobes turns to steam causing explosive brecciation of the glass (Fuller, 1931). Typically, this sort of basalt-water interaction produces brecciated glass and pillows. This glassy material and basaltic debris tends to accumulate in place and produce a pillow-palagonite complex with hyaloclastic debris and basalt pillows accumulating in foreset beds.

The fluvial deposition of upper Troutdale Formation hyaloclastites in the lower Columbia River Gorge does not resemble the debris accumulation of a pillow-palagonite complex. A more appropriate name for the upper Troutdale basaltic glass-rich sediment is reworked or fluvially-deposited hyaloclastite based on the nomenclature of Silvestri (1961). A mechanism that could form the reworked hyaloclastites of the upper Troutdale Formation requires that the hyaloclastic debris be actively removed from the source lavas in order to produce the near purely hyaloclastic sedimentary beds found in the Troutdale Formation.

Lavas erupted into a major river such as the Columbia would form hyaloclastic debris. The river, although it may be constricted by the lava flow entering its course, would continue to flow past the lava flow. River flow over and around the erupting lava would continuously produce and transport hyaloclastic debris along with crystalline 
fragments eroded from flows and pillows. Partial damming of the river by lavas, along with the sudden addition of hyaloclastic sediment, could lead to the deposition of a sheet or apron of sediment downstream. After an eruptive period it is likely that the river channel would cut into the hyaloclastic debris sheet and rework some of it.

It is likely that the interlayering of hyaloclastic or vitric sands with arkosic sands, gravels and muds of the Portland Well Field is the result of intermittent periods of high-alumina basalt eruptive activity along the course of a river draining over a flood plain in the Portland area. During eruptive periods basaltic hyaloclastic sediment would choke the river system and result in the deposition of hyaloclastites. Between major eruptive events, non-locally derived, ancestral Columbia River sediment and mixed local and non-local sediment would be deposited.

\section{Geochemical Analysis}

Sediment, hyaloclastite and basalt samples were analysed at Portland State University using Instrumental Neutron Activation Analysis (INAA). Elements detected with acceptable experimental errors are: $\mathrm{Na}, \mathrm{K}, \mathrm{Sc}, \mathrm{Cr}, \mathrm{Fe}, \mathrm{Co}, \mathrm{Cs}$, Hf, Ta, the rare earth elements $\mathrm{La}, \mathrm{Ce}$, $\mathrm{Sm}, \mathrm{Eu}, \mathrm{Tb}, \mathrm{Yb}$ and $\mathrm{Lu}$, and $\mathrm{Th}$. Eighty-seven samples (not including standards) were analyzed in three experiments. Appendix A gives type of material sampled, location, formation and member, and experiment number for samples analyzed. Appendix B gives a more detailed description of the analytical procedure along with data tables showing elemental concentrations determined for each sample. Three vitric 
separate samples were sent to $\mathrm{Dr}$. Peter Hooper's x-ray fluorescence $1 \mathrm{ab}$ at Washington State University for major oxide analysis. 
CHAPTER II

NON-HYALOCLASTIC SEDIMENTARY ROCKS OF THE SANDY RIVER MUDSTONE AND TROUTDALE FORMATION

\section{Lithology}

Previous workers (Williams, 1916; Bretz, 1917; Allen, 1932;

Hodge, 1938; Trimble, 1957, 1963; Cole, 1983; Tolan, 1982) have described the lithology of beds currently included in the Troutdale Formation and the Sandy River Mudstone. Most descriptions of the Troutdale Formation note the two distinct lithologies that are included in Tolan and Beeson's (1984) upper and lower members of the Troutdale Formation. Sediment, that for the most part, is correlative with the lower member paleo-Columbia River gravels is described as fluvial gravels composed of basaltic pebbles and cobbles along with nonvolcanic pebbles of granitic and metamorphic rock types of which quartzite is most prominent1y noted. Sand lenses and matrix within these gravels are typically described as a micaceous arkose. Sediment that composes the upper member of the Troutdale Formation has been described as basaltic tuffs, agglomerates or hyaloclastites and basaltic gravel attributed to a volcanic origin. Non-locally-derived clasts such as quartzite pebbles and arkosic sand are less common in the upper member.

The lithology of the Sandy River Mudstone is described as sandy mudstone, mudstone and claystone with a few sand and gravel beds (Trimble, 1963). Trimble (1963) noted the presence of volcanic ash 
beds in the Sandy River Mudstone southeast of Oregon City, Oregon. Trimble's (1963) Sandy River Mudstone-Troutdale Formation transition has been estimated to be equivalent to the transition from lower member to upper member Troutdale Formation (Tolan and Beeson, 1984).

Within the well area the hyaloclastic beds are interbedded with intervals of non-hyaloclastic sediment. These sediments are predominantly muds and sandy muds with a few clay or claystone beds. A 30- to 90-foot-thick gravel bed is found near the base of the TSA unit (Willis, 1977). The generally fine grained non-hyaloclastic beds account for up to 50 percent of the sediment within the well interval that contains the RC, TSA and UTSA hyaloclastic units (Figure 6). Fine-grained sediment also dominates below the interval containing the RC, TSA and UTSA hyaloclastic units.

The Troutdale Formation samples taken from the well area were assigned to the either the upper or lower Troutdale Formation of Tolan and Beeson (1984). The presence of hyaloclastic beds was used as a determinator for upper member Troutdale Formation. Sediment below the lowest hyaloclastic sediment and above the inferred Columbia River basalt basin floor is called lower Troutdale Formation. This was done for two reasons. One is to establish a time line within the well area sediments equivalent to the base of the upper Troutdale Formation. The other is to separate the fine grained upper member Troutdale Formation sediment from texturally similar Sandy River Mudstone.

Sediment samples from the well area and outcrop locations were analyzed geochemically and petrographically to determine if there is a change in the non-hyaloclastic sediment related to the change from 
lower to upper member of the Troutdale Formation in the well area and to determine whether the lower member of the Troutdale Formation and the Sandy River Mudstone are geochemically and lithologically similar.

Petrographic Line Counts

Petrographic line counts were performed on suites of samples collected from wells 1 N/2E $29 \mathrm{DA}$ and $1 \mathrm{~N} / 3 \mathrm{E} 20 \mathrm{CB} 2$ and outcrop samples from the Sandy River Mudstone and Troutdale Formation to characterize their lithology. Comparisons were made between clastic composition of upper nember and lower member Troutdale Formation sand from the wells and the lower member Troutdale and Sandy River Mudstone from the type areas near Troutdale and Bridal Veil, Oregon.

Sand samples were sieved to -25 to +120 mesh to insure uniformity of grain size and to facilitate the mechanics of mounting and staining of feldspar grains. Sample splits were mounted on petrographic slides in Canada balsam and hand lapped to expose all grains to staining. Each slide was examined to determine general lithologic composition, then stained for potassium feldspar and plagioclase. After staining, each grain mount was line counted. The line count results are given in Table I.

Samples of the lower member Troutdale Formation from the well area and the Bridal Veil Channel, and the Sandy River Mudstone from outcrops along the Sandy River are arkosic arenites (Figure 7) according to the classification of McBride (1963). Sample 1-1120 is an exception, this sample comes from a sideromelane-bearing gravel 250-300 feet below the transition to upper member Troutdale Formation as defined by the presence of vitric sand beds. Upper member Troutdale 
TABLE I

SEDIMENT LINE COUNT DATA *

\begin{tabular}{|c|c|c|c|c|c|c|c|c|}
\hline SAMPLE & $1-490$ & $1-683$ & $1-935$ & $1-1120$ & $1-1200$ & $2-1000$ & $5-135$ & $5-440$ \\
\hline UNIT & Ttu & Ttu & Ttu & $T t 1$ & $T t 1$ & Tt1 & Ttu & Ttu \\
\hline $\begin{array}{l}\text { QUARTZ } \\
\text { K-FELD } \\
\text { PLAG } \\
\text { LITHIC } \\
\text { MAFIC } \\
\text { OPAQUE } \\
\text { MICA }\end{array}$ & $\begin{array}{r}17 . \\
10 . \\
8 . \\
60 \\
2 . \\
1 . \\
1 .\end{array}$ & $\begin{array}{r}6 . \\
2 . \\
23 . \\
57 . \\
11 . \\
0 . \\
1 .\end{array}$ & $\begin{array}{r}16 . \\
6 . \\
23 . \\
48 . \\
4 . \\
1 . \\
4 .\end{array}$ & $\begin{array}{l}17 . \\
11 . \\
20 . \\
47 . \\
3 . \\
2 . \\
1 .\end{array}$ & $\begin{array}{l}23 . \\
16 . \\
27 \\
24 \\
4 . \\
2 . \\
5 .\end{array}$ & $\begin{array}{l}30 . \\
13 . \\
19 . \\
32 . \\
4 . \\
1 . \\
1 .\end{array}$ & $\begin{array}{c}12 . \\
7 \\
12 \\
64 \\
3 . \\
0 \\
2\end{array}$ & $\begin{array}{r}20 . \\
5 . \\
20 . \\
45 . \\
5 . \\
3 . \\
3 .\end{array}$ \\
\hline SAMPLE & $5-535$ & $5-670$ & $5-795$ & $5-970$ & $5-1100$ & GCR-2 & $B V-4 A$ & $B V-4 B$ \\
\hline UNIT & Ttu & Ttl & $T t 1$ & $T t 1$ & $T t 1$ & Tsr & $T t 1$ & Ttu \\
\hline $\begin{array}{l}\text { QUARTZ } \\
\text { K-FELD } \\
\text { PLAG } \\
\text { LITHIC } \\
\text { MAFIC } \\
\text { OPAQUE } \\
\text { MICA }\end{array}$ & $\begin{array}{r}16 . \\
3 . \\
10 . \\
65 . \\
3 . \\
2 . \\
3 .\end{array}$ & $\begin{array}{l}38 . \\
14 . \\
22 . \\
21 . \\
3 . \\
1 . \\
1 .\end{array}$ & $\begin{array}{r}36 . \\
13 . \\
28 . \\
14 . \\
5 . \\
3 . \\
0 .\end{array}$ & $\begin{array}{c}31 . \\
12 . \\
17 . \\
29 . \\
8 . \\
3 . \\
0 .\end{array}$ & $\begin{array}{r}26 . \\
8 . \\
19 . \\
30 . \\
11 . \\
2 . \\
4 .\end{array}$ & $\begin{array}{l}31 . \\
10 . \\
23 . \\
25 . \\
7 . \\
1 . \\
3 .\end{array}$ & $\begin{array}{r}32 . \\
17 \\
22 . \\
24 \\
2 . \\
1 . \\
2 .\end{array}$ & $\begin{array}{c}15 . \\
13 . \\
17 . \\
37 . \\
10 . \\
6 . \\
1 .\end{array}$ \\
\hline
\end{tabular}

* Expressed as percentage 

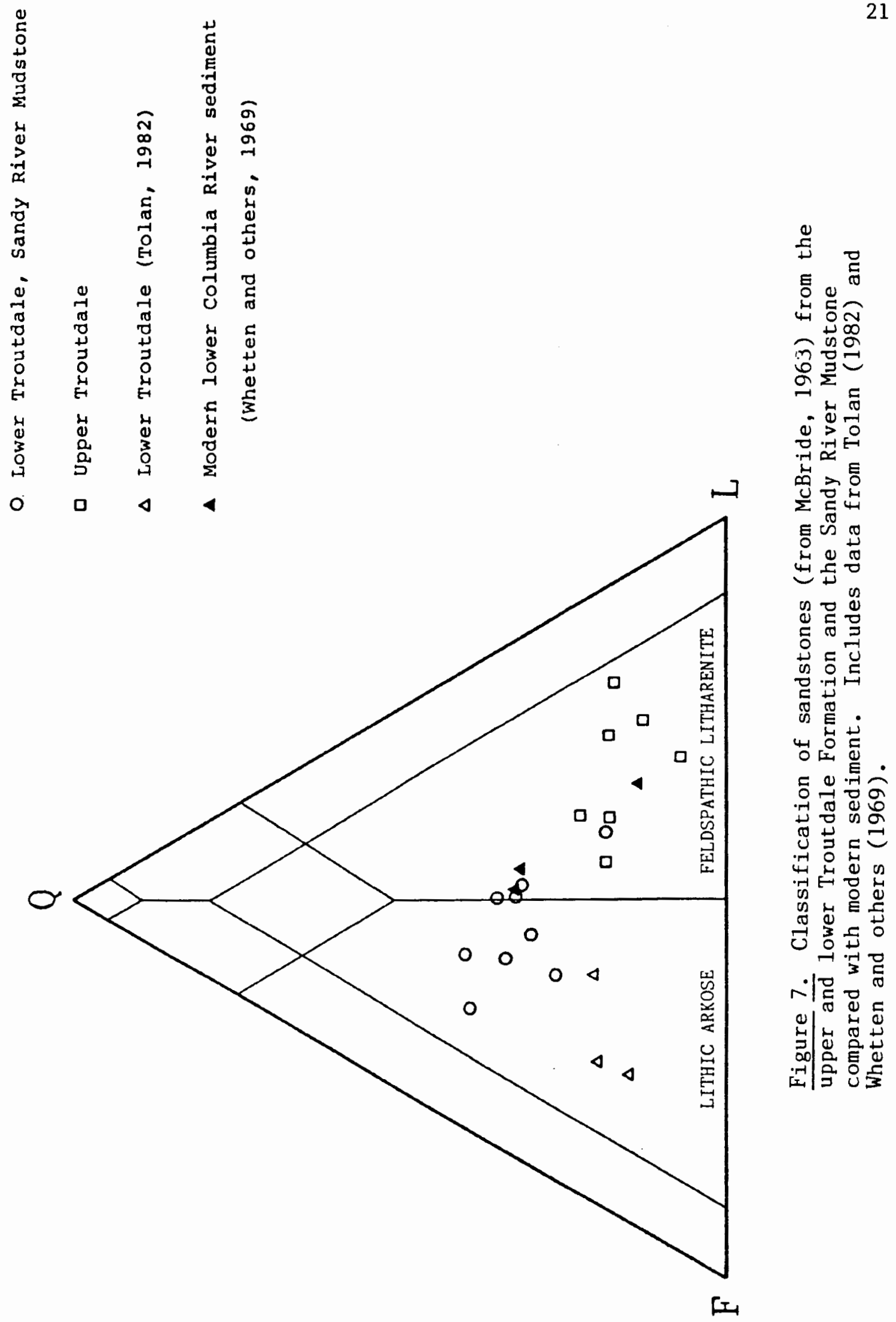
Formation sands from both the well area and the Bridal Veil section plot in the feldspathic litharenite field (Figure 7). Modern lower Columbia River sediment data from Whetten and others (1969) form a field that overlaps lower and upper member Troutdale Formation data. Modern Columbia River sand becomes increasingly lithic downstream, from above The Dalles to the Sandy River (Whetten and others, 1969). Tolan's (1982) lower member Troutdale sands are somewhat more feldspathic than samples counted in this study. However, total feldspar plus quartz and total lithic grains are similar.

\section{Sediment Geochemistry}

The Sandy River Mudstone, lower member Troutdale Formation and upper member Troutdale Formation are characterized by trace and minor element concentrations. Sediment geochemical data are used to determine the transition from lower to upper member Troutdale Formation in the well area and to aid in determining if Sandy River Mudstone is similar to either member of the Troutdale Formation.

Most high-alumina basalts of the High Cascade Group basalts and Boring Lavas in the northern Oregon Cascade Range and Portland area are higher in chromium than typical modern Columbia River sediment by a factor of two to six. Iron, scandium and cobalt are also found in 50\% to $100 \%$ higher concentrations in the high-alumina lavas than in modern sediment (Whetten and others, 1969; Darolyn Burch, 1980 unpublished manuscript). Modern sediment was expected to be fairly similar to prehigh-alumina basalt-derived sediment because the ancestral Columbia River appears to have drained an area geologically similar to its present drainage. Fecht and others (1983) state that a post-Columbia 
River basalt, paleo-Columbia River system drained highlands surrounding the Columbia Plateau. This is a similar area to that drained by the modern Columbia River systen. Figure 8, a generalized bedrock type map of the modern Columbia River, shows the distribution of volcanic and non-volcanic rocks in the Columbia River Basin.

INAA Experiment 7T (see appendix B) was completed with sediment samples from well $1 \mathrm{~N} / 3 \mathrm{E} 20 \mathrm{CB} 2$ to determine if a geochemical signature could be identified for the upper and lower Troutdale Formation sediments in this well. Samples were sieved to -200 mesh to insure inter-sample uniformity of grain size and to remove extraneous material that may have fallen down hole or broken off storage containers. The procedure used in experiment $7 \mathrm{~T}$ was repeated in experiment $7 \mathrm{H}$ (see appendix B) using samples taken at approximately twenty five foot intervals from sediment below the obvious base of the TSA and/or RC hyaloclastite beds in well holes 1N/2E 29DA and 1N/3E 31CD.

Geochemical data for sediment samples from wel1 1N/3E 20CB2 (experiment 7T) indicate a distinct geochemical difference between sediment below sample 5-535 and samples above 5-535 characterized by an increase of chromium, iron, scandium, and cobalt at sample 5-535 and above. This is associated with the presence of hyaloclastic material and other high-alumina basalt derived clastic material in the sediment in the interval between samples 5-535 and 5-135 in well $1 \mathrm{~N} / 3 \mathrm{E} 20 \mathrm{CB} 2$. A graph of Sc versus Co (Figure 9) shows the trend encountered. Samples $5-535,5-440,5-400$ and 5-165 show some deviation from the group of lower member Troutdale Formation and Sandy River Mudstone toward the area of the vitric separates and lithic arenites in Figure 9. Two 
Non-volcaniclastic sedimentary rocks,
metamorphic rocks and plutonic rocks.

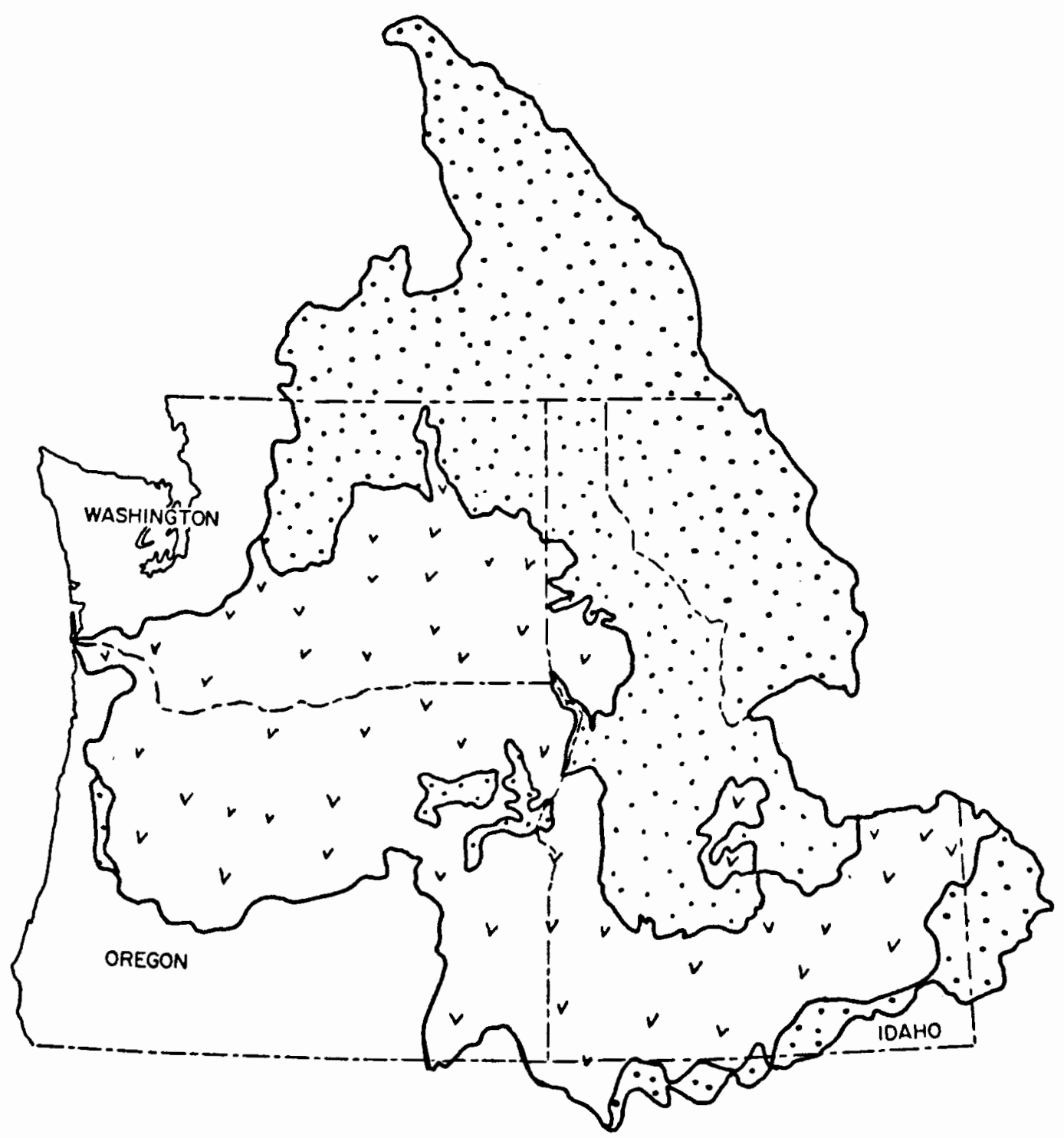

Figure 8. Volcanic and non-volcanic bedrock geology of the modern Columbia River system. Modified after Whetten and others (1969). 


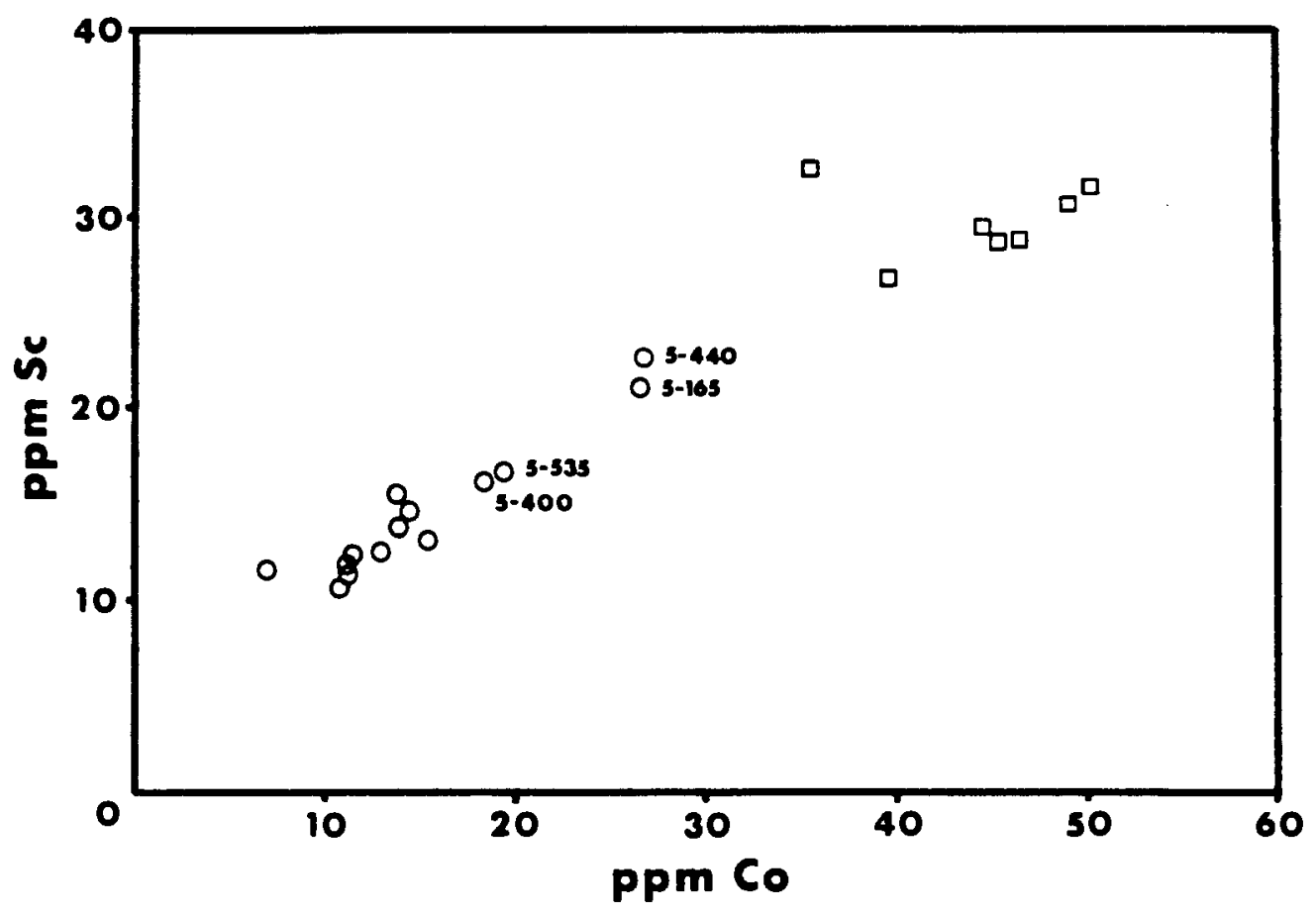

Figure 9. Scandium versus cobalt graph for non-hyaloclastic sediments, o; hyaloclastic sediments and vitric separates, 0 ; for INAA experiment $7 \mathrm{~T}$ samples from well $1 \mathrm{~N} / 3 \mathrm{E} 20 \mathrm{CD} 2$ and field samples.

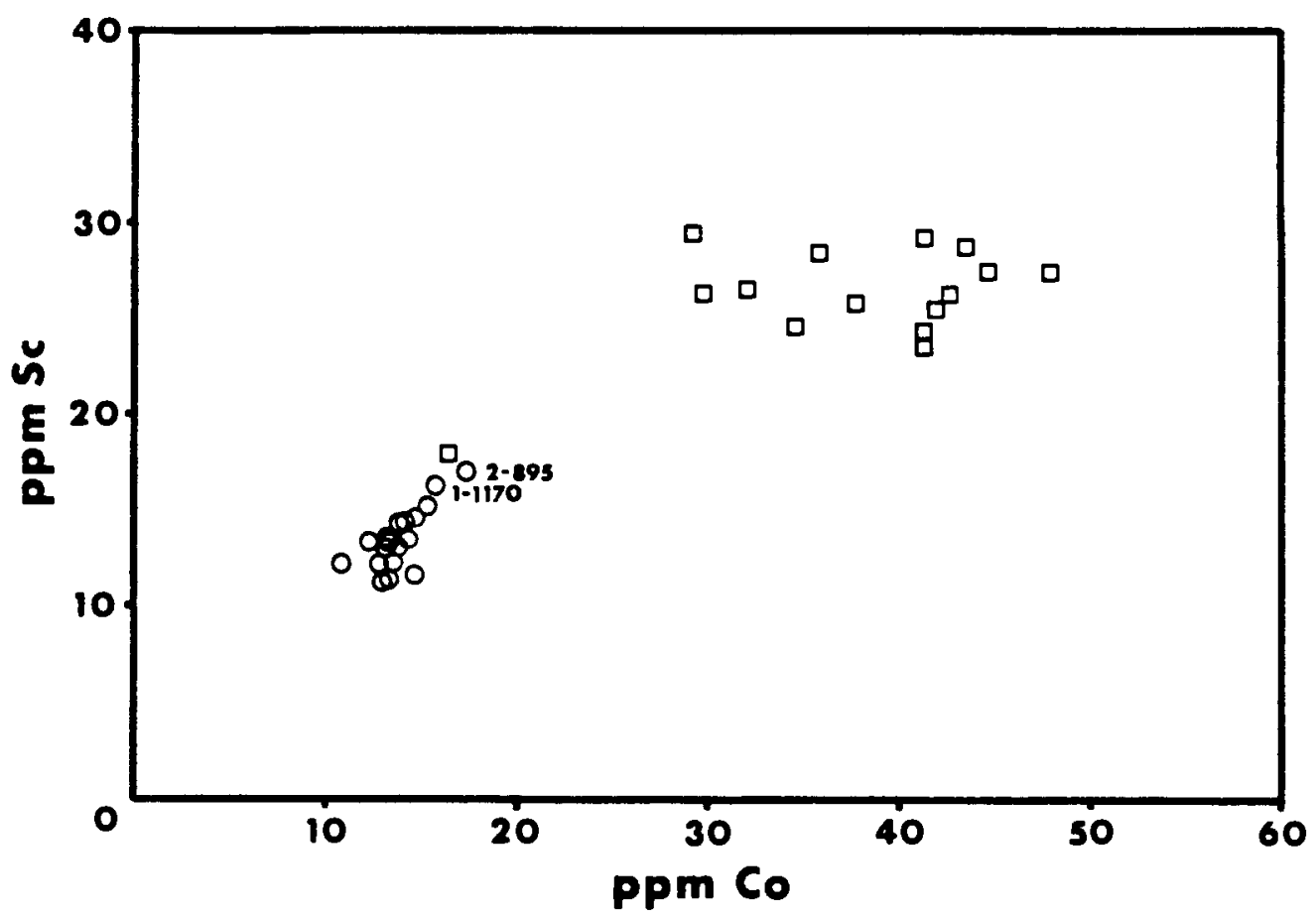

Figure 10. Scandium versus cobalt graph for sediments from below the $\overline{R C}$ and TSA hyaloclastic sediment, 0 ; and vitric separates and palagonites, $\square$; from wells $1 \mathrm{~N} / 2 \mathrm{E} 29 \mathrm{DA}$ and $1 \mathrm{~N} / 2 \mathrm{E} 31 \mathrm{CD}$. 
samples from the the upper member in well 1N/3E 20CB2, 5-135 and 5-305 fall within the lower member and Sandy River Mudstone group.

Results of INAA experiment $7 \mathrm{H}$, using suites of sediment from below the base of the obvious hyalocatic beds in wells 1N/2E 29DA and $1 N / 3 E 31 C D$, indicate no sediment group characterized by higher amounts of chromium, scandium, cobalt and iron similar to the upper sediments in $1 \mathrm{~N} / 3 \mathrm{E}$ 20CB2. Figure 10 plots Sc versus Co for INAA experiment $7 \mathrm{H}$ samples indicating no significant amount of hyaloclastic material or other high-alumina basalt derived sediment is detected based on the criteria established for well hole 1N/3E 20 CB2.

The increases in chromium, iron, scandium and cobalt found above sample 5-535 in well hole 1N/3E 20CB2 are similar to what might be caused by adding high-alumina basalt-derived sediment of the composition found in the analyzed hyaloclastites. Sediment beds in the high chromium-scandium-iron-cobalt group are intimately associated with the TSA and RC hyaloclastite units. The sediment chemistry group characterized by higher concentrations of $\mathrm{Cr}, \mathrm{Fe}, \mathrm{Sc}$ and $\mathrm{Co}$ is evident only down to the base of the TSA and RC hyaloclastite units. Sediment from between the stratigraphically lowest hyaloclastite-bearing unit (LRC) at a well depth of 1125 feet ( -925 feet elev.) in 1N/2E 29DA and the base of the TSA-RC hyaloclastites shows no $\mathrm{Cr}, \mathrm{Fe}, \mathrm{Sc}$ and $\mathrm{Co}$ enrichment similar to the sediment in proximity to the TSA and RC hyaloclastite units.

Total elemental abundances can vary with sediment texture, e.g. mudrocks tend to have higher trace element concentrations than sands (Haskin and others, 1966), while relative concentrations are usually 
alike for most sediments from a similar type geologic provenance (Bhatia and Taylor, 1981). Generally, in sediment, rare earth element abundances tend to increase with progressively more evolved source areas. The lowest concentrations are associated with undissected magmatic arcs. Dissected magmatic arcs and more evolved continental areas would have increasingly higher concentrations of rare earth elements and thorium. More evolved continental crust rocks tend to have lower La/Th ratios (Bhatia and Taylor, 1981; Nance and Taylor, 1976).

A graph of lanthanum versus thorium (Figure 11) was drawn to help display possible variations in geochemistry caused by sediment contributions from differing source areas based on the relative amounts of these elements. Most sediment samples plotted on the lanthanum to thorium graph fell on or near a line with a slope of 4 , indicating a relatively constant lanthanum to thorium ratio. This is near the maximum lanthanum to thorium ratio found in fine grained sediments (McLennan and others, 1980). Sediments from the Troutdale Formation with the lowest total amount of lanthanum and thorium are associated with vitric-bearing gravels and sands.

When the distribution of the Troutdale Formation and Sandy River Mudstone samples in Figure 11 is compared to the provenance type areas of Bhatia and Taylor (1981), the Troutdale Formation-Sandy River Mudstone sediment appears to be most similar to the field of sediment derived from a dissected magmatic arc.

Examination of the sediment geochemical data suggests that the fine sediment fraction sampled ( -200 mesh) is biased toward sediment 


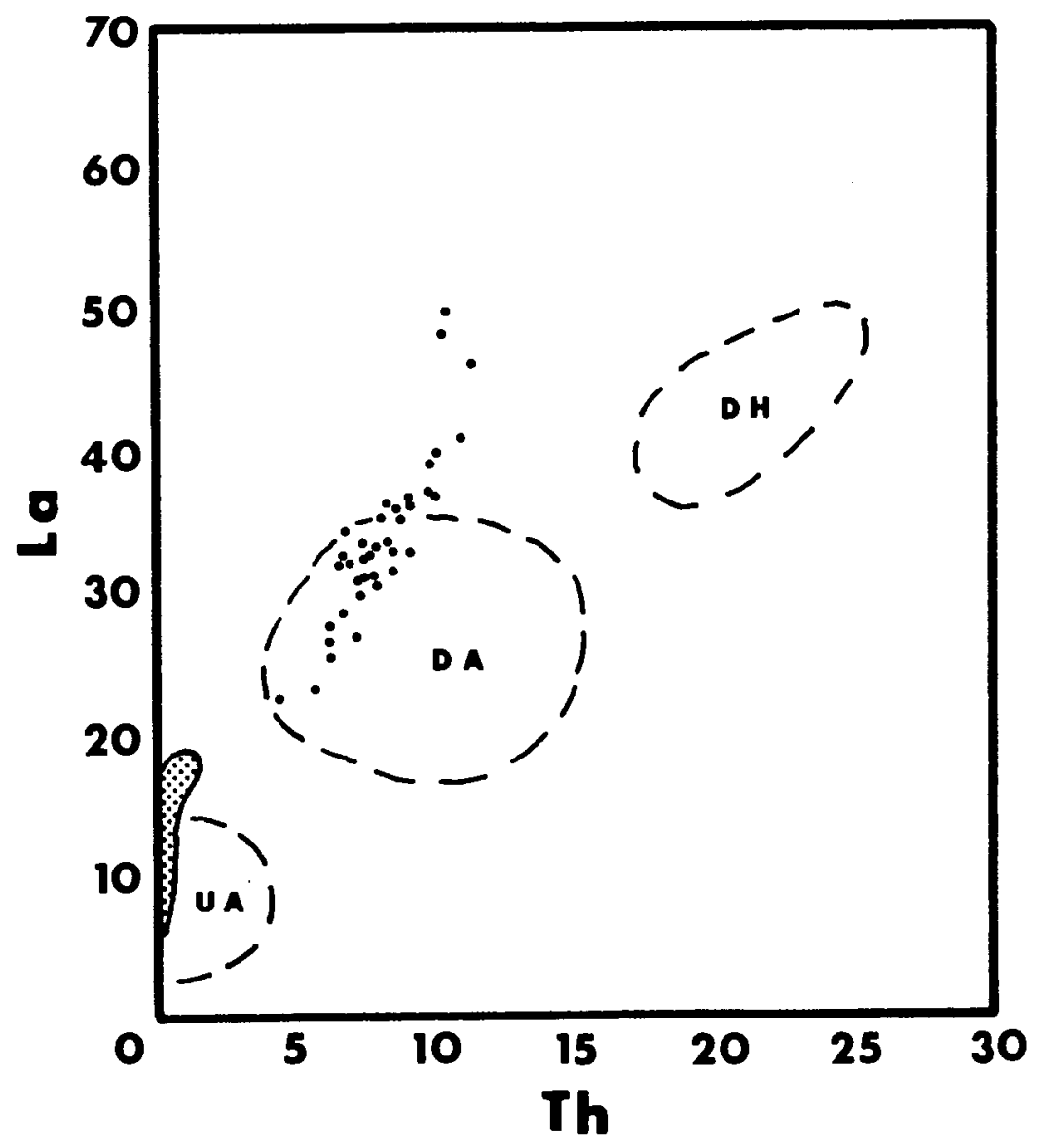

Figure 11. Lanthanum versus thorium for sediments from the upper and lower Troutdale Formation and Sandy River Mudstone. Stippled area represents vitric material. Tectonic classification from Bhatia and Taylor (1981); UA=undissected magmatic arc, DA=dissected magmatic arc, and $\mathrm{DH}=\mathrm{dissected}$ highland. 
derived from all portions of the drainage basin. Examination of whole sediment samples with a binocular microscope showed that the locally-derived volcanic sediment in the Troutdale Formation tends to be coarser and therefore not as well represented in the finer fraction. In extreme cases when predominately volcanic detritus is deposited, there would a higher likelihood of detecting its presence geochemically. This is the case with the several samples taken from the upper portion of well 1N/3E $20 \mathrm{CB} 2$. 


\section{CHAPTER III}

\section{VITRIC BEDS AND THEIR USE AS STRATIGRAPHIC MARKERS}

\section{Genera1}

No single criterion served to identify specific hyaloclastite beds. Vitric units within the well area are divided into four groups based on statigraphic position, lithology and geochemical characteristics, as determined by INAA. The four well area groups of hyaloclastite and vitric material-bearing sand were assigned abbreviated names (Figure 6) based on informal hydrogeologic unit names of Hoffstetter (1984). The four hyaloclastic units from lower to uppermost are the LRC, RC, TSA and UTSA. The TSA and RC hyaloclastic units contain the bulk of the vitric material deposited in the well area. Along with the UTSA hyaloclastic beds the TSA and RC units are equivalent to the type Troutdale section of Trimble (1963) and the informal upper member Troutdale Formation of Tolan and Beeson (1984). The lower Rose City (LRC) hyaloclastite unit is not a hyaloclastite but a sideromelane-bearing sandy gravel. The LRC is included in the lower Troutdale Formation of the well area. Cross-sections showing correlation of hyaloclastic units in the well area based on natural gamma logs, trace element geochemistry and lithology are compiled in Appendix C.

The TSA unit can be found in all wells sampled in this study. Other vitric beds are missing in at least one hole. Material of the upper Troutdale sandstone aquifer (UTSA) unit is not found in holes 
$1 N / 3 E 33 A D$ or $1 N / 3 E 20 C B 2$ in the eastern portion of the well area. Here it appears to have been either removed or not deposited prior to deposition of the Parkrose gravel aquifer. Well 1N/2E 29DA, which has the thickest section of vitric-bearing sediments, does not appear to have a Rose City (RC) hyaloclastite unit. However, some sediment in wel1 1N/2E 29DA below sample 1-715, which may be correlative with the Rose City (RC) hyaloclastite, was not available for analysis due to circulation loss during drilling. The LRC is a geochemically unique hyaloclastic debris-bearing sandy gravel in well 1N/2E 29DA at the 1150-foot to 1120-foot well depth and possibly in trace amounts in a gravel at 945 foot level in well 1N/3E 31CD.

Hyaloclastite Lithology

Unpalagonitized well area beds consist of medium to coarse grained subangular to subrounded, very dark brown vitric sand or in many cases vitric sand mixed with arkosic sand, mud and gravel. The only macroscopic lithologic difference between the well area hyaloclastite units is finer grain size and the presence of palagonitization in some of the beds. Most vitric grains have a very thin bluish-gray to light brown rind or veneer. Tiny clear to light yellow clusters of plagioclase and olivine crystals can be seen with the unaided eye or a 10-power hand lense.

In outcrop, vitric sands or hyaloclastites appear much more weathered and palagonitized than those encountered by well drilling in the Portland basin. Outcrop hyaloclastites are usually deep rusty brown or red to orange and sometimes yellow and pink in color. In many outcrops only small cores of sideromelane glass remain unpalagonitized. 
In some beds orange-yellow pumice clasts are mixed with vitric and crystalline grains.

Palagonite is a term coined to describe a yellow to brown waxy substance found in basaltic tuffs near Palagonia, Sicily (von Waltershausen, 1845, in Fisher and Schmincke, 1984, p.314) that is commonly applied to altered clastic or fragmental basaltic glass deposits. Palagonitization takes place under various temperature and chemical conditions ranging from hydrothermal alteration to surficial weathering processes (Fisher and Schminke, 1984). Non-marine, lowtemperature palagonitization takes place rapidly above the water table in percolating groundwater, and produces clays, zeolites, calcite and opal (Hay and Iijima, 1968). Below the water table, palagonitization takes place much more slowly (Christensen and Gilbert, 1964 in Hay and Iijima, 1968). The clear, glassy unpalagonitized character of most buried well area hyaloclastites suggests that they were buried before they were affected by appreciable weathering and palagonitization.

\section{Hyaloclastite Petrography}

Several grain mount slides and thin sections, made from geochemically analyzed vitric separate samples, were examined using a petrographic microscope. Sideromelane grains in thin sections made from well area TSA and RC bed sediment cuttings are indistinguishable based on estimated percentages of crystals present and textural characteristics. Outcrop samples from the Sandy River area and the Bridal Veil Channel were nearly identical to the TSA and RC well samples. All are dark brown glass with tiny tabular and lath shaped plagioclase crystals, clusters of olivine grains and very small, well- 
formed olivine crystals in the glass groundmass. The geochemically unique sample from the LRC, sample 1-1125G, is petrographically similar to the other hyaloclastites examined.

Sample BV-9, the uppermost sample that was geochemically analyzed from the Bridal Veil section, is composed predominantly of clasts of subophitic olivine basalt. Red iddingsite occurs as rinds on the olivine and as smaller grains in the matrix. Iddingsite is an alteration following olivine (Deer and others, 1966). Red iddingsite occurs commonly in high-alumina basalts of the High Cascades and the Boring Lavas (Peck and others, 1964; Trimble, 1963; Wise, 1969). However, iddingsite has not been found to be abundant in the hyaloclastic clasts petrographically examined.

Hyaloclastite Geochemistry

Thirty-four well area and outcrop samples of hyaloclastic and lithic sand were analyzed using INAA. In most samples, weathered hyaloclastites and vitric-bearing sediment were manually picked for clean unweathered glass clasts. Unweathered glass was separated to provide a sample composed exclusively of fresh basaltic glass to avoid possible weathering and alteration effects on trace element concentrations. Several well cutting samples and outcrop samples in INAA experiments $7 \mathrm{~T}$ and $7 \mathrm{~K}$ are cemented, palagonitic hyaloclastites or lithic sands for which it was impractical or impossible to separate the glass from the rest of the sample. In these cases the entire rock sample was analyzed.

A more complete description of the analytical procedure and a complete table of results is in appendix B. Results of geochemical 
analyses are given in Table II. Appendix A lists sediment type, location, and stratigraphic unit for all the analyzed vitric samples and Plate I shows the stratigraphic position of the samples. Major oxide contents for representative vitric separates from the TSA, RC and LRC vitric units are in (Table III).

Geochemically, as well as lithologically, the hyaloclastite units appear to come from very similar source material. Major oxide geochemical data indicate that the TSA and RC vitric separates are derived from high-alumina basalts. The RC and TSA units are, essentially, geochemically indistinguishable from each other except for a tendency toward slightly higher chromium concentration (about $10 \%$ higher) in the TSA hyaloclastite. The UTSA unit is unique in its lower $\mathrm{Cr}$, Na and $\mathrm{K}$ content and higher amounts of light rare earth elements. Figure 12, a graph of chromium versus lanthanum/samarium shows variation within the group.

Due to its uniquely deep stratigraphic position a vitric separate from 1-1125G was sent for major oxide analysis to determine if it was derived from a Columbia River Basalt Group flow postdating those found in western Oregon. Major oxide chemistry shows the sample 1-1125G vitric material to be a high-alumina basalt dissimilar to the TSA-RC material. Higher concentrations of titania $\left(\mathrm{TiO}_{2}\right)$ and $\mathrm{P}_{2} \mathrm{O}_{5}$ set the LRC apart from the TSA-RC vitric material (Figure 19).

Vitric sand from stratigraphic sections along the Sandy River and Bridal Veil channel appear to be geochemically and lithologically indistinguishable from the TSA and probably the RC vitric units of the well area. The higher chromium concentration in the outcrop samples is 
TABLE II

INAA ELEMENTAL CONCENTRATIONS FOR VITRIC SEPARATES (G), LITHIC AND VITRIC SANDS, AND LAVAS (B) * \#

\begin{tabular}{|c|c|c|c|c|c|c|c|c|c|c|c|c|c|c|}
\hline SAMPLE & & & & & & Ce & & Sm & & Eu & & Tb & & $y_{b}$ \\
\hline $1-710$ & 1.01 & 0.01 & 12.0 & 0.3 & & D. & 3.43 & 0.04 & 1.15 & 0.06 & 0.41 & 0.07 & 2.0 & 0.3 \\
\hline $1-715$ & 1.20 & 0.01 & 10.4 & 0.3 & & D. & 3.44 & 0.04 & 1.11 & 0.06 & 0.62 & 0.08 & 2.3 & 0.3 \\
\hline & 1.32 & 0.01 & 11.0 & $\begin{array}{l}0.3 \\
0.4\end{array}$ & 220 & Di.2 & 2.91 & 0.04 & $\begin{array}{l}0.91 \\
1.04\end{array}$ & $\begin{array}{l}0.05 \\
0.06\end{array}$ & $\begin{array}{l}0.45 \\
0.54\end{array}$ & $\begin{array}{l}0.07 \\
0.07\end{array}$ & $\begin{array}{l}1.7 \\
2.7\end{array}$ & $\begin{array}{l}0.2 \\
0.3\end{array}$ \\
\hline $\begin{array}{l}3-240 \\
5-145\end{array}$ & $\begin{array}{l}0.00 \\
0.99\end{array}$ & 0.01 & 27.6 & 0.5 & 14.6 & 1.7 & $\begin{array}{l}3.43 \\
5.57\end{array}$ & 0.04 & 1.76 & 0.08 & 0.86 & 0.09 & 4.7 & 0.4 \\
\hline $1160 \mathrm{PMR}$ & 1.41 & 0.01 & 7.2 & 0.4 & 26.9 & 1.7 & 2.55 & 0.03 & 1.45 & 0.07 & 0.80 & 0.08 & 1.6 & 0.3 \\
\hline LSWSS & 1.64 & 0.01 & 21.7 & 0.5 & & D. & 5.08 & 0.04 & 0.91 & 0.06 & N. & & 3.2 & 0.3 \\
\hline SLTSTSS & 0.90 & 0.01 & 15.7 & 0.4 & 20.6 & 1.9 & 3.93 & 0.04 & 1.17 & 0.07 & 0.62 & 0.09 & 2.1 & 0.3 \\
\hline $3-3486$ & 1.28 & 0.01 & 12.3 & 0.3 & & D. & 3.68 & 0.04 & 1.22 & 0.06 & 0.62 & 0.07 & 2.2 & 0.3 \\
\hline $2-600 G$ & 1.30 & 0.01 & 4.5 & 0.2 & & & 2.24 & 0.03 & 0.91 & 0.05 & 0.44 & 0.07 & 2.0 & 0.3 \\
\hline $3-387 G$ & .12 & 0.01 & 4.6 & 0.3 & & D. & 2.49 & 0.03 & 0.95 & 0.06 & 0.44 & 0.07 & 2.2 & 0.3 \\
\hline $5-180 G$ & 1.85 & 0.01 & 5.6 & 0.3 & & D. & 2.42 & 0.03 & 0.91 & 0.05 & 0.42 & 0.07 & 2.1 & 0.3 \\
\hline $6-320 G$ & 2.00 & 0.01 & 6.0 & 0.3 & & D. & 2.55 & 0.04 & 1.08 & 0.06 & 0.42 & 0.08 & 2.4 & 0.3 \\
\hline $6-345 \mathrm{G}$ & 2.01 & 0.01 & 5.0 & 0.3 & & D. & 2.40 & 0.04 & 0.95 & 0.06 & 0.61 & 0.09 & 2.3 & 0.3 \\
\hline P28-375G & 2.26 & 0.01 & 4.9 & 0.3 & 16.0 & 2.0 & 2.78 & 0.05 & 1.00 & 0.07 & 0.36 & 0.08 & 1.4 & 0.4 \\
\hline T34-390G & 2.27 & 0.01 & 5.3 & 0.3 & 16.4 & 1.5 & 2.80 & 0.05 & 0.99 & 0.07 & 0.50 & 0.09 & 1.9 & 0.5 \\
\hline$T B-3 G$ & 2.05 & 0.01 & 5.1 & 0.3 & 16.3 & 1.4 & 2.70 & 0.05 & 1.01 & 0.07 & 0.42 & 0.08 & 2.9 & 0.5 \\
\hline BL-2G & 2.01 & 0.01 & 4.8 & 0.3 & 14.8 & 1.4 & 2.69 & 0.05 & 1.02 & 0.07 & 0.42 & 0.08 & 2.4 & 0.4 \\
\hline CHPT & 0.68 & 0.01 & 9.7 & 0.3 & & D. & 2.58 & 0.03 & 0.96 & 0.06 & N. & D. & 2.2 & 0.2 \\
\hline WR-1 & 1.67 & 0.01 & 8.9 & 0.3 & 22.3 & 1.5 & 3.82 & 0.06 & 1.12 & 0.07 & 0.53 & 0.09 & 2.6 & 0.4 \\
\hline$W R-5 G$ & 2.07 & 0.01 & 5.2 & 0.3 & 14.6 & 1.5 & 2.79 & 0.06 & 0.97 & 0.07 & 0.47 & 0.08 & 2.5 & 0.4 \\
\hline WR-8G & 2.10 & 0.01 & 7.3 & 0.3 & 18.4 & 1.5 & 3.29 & 0.06 & 1.08 & 0.07 & 0.47 & 0.09 & 2.7 & 0.4 \\
\hline GCR-4G & 2.10 & 0.01 & 8.5 & 0.3 & 20.6 & 1.5 & 3.60 & 0.05 & 1.21 & 0.07 & 0.62 & 0.08 & 2.6 & 0.5 \\
\hline BV-96 & 1.85 & 0.01 & 6.9 & 0.3 & 17.5 & 1.6 & 3.15 & 0.05 & 1.12 & 0.10 & 0.61 & 0.09 & 2.3 & 0.5 \\
\hline$B V-2 G$ & 1.98 & 0.01 & 7.1 & 0.3 & 16.6 & 1.5 & 3.34 & 0.06 & 1.07 & 0.07 & 0.48 & 0.08 & 2.7 & 0.5 \\
\hline$B V-7 G$ & 1.99 & 0.01 & 11.4 & 0.3 & 23.5 & 15 & 3.89 & 0.06 & 1.2 & 0.07 & 0.52 & 0.08 & 3.0 & 0.5 \\
\hline $2-750 G$ & 2.30 & 0.01 & 5.1 & 0.3 & & & 2.68 & 0.04 & 1.06 & 0.06 & 0.53 & 0.08 & 2.3 & 0.4 \\
\hline & 2.19 & 0.01 & 7.9 & 0.3 & & D. & 3.16 & 0.04 & 1.15 & 0.06 & 0.51 & 0.08 & 2.4 & 0.3 \\
\hline $3-570 G$ & 2.22 & 0.01 & 5.3 & 0.3 & & & 2.61 & 0.04 & 1.01 & 0.06 & 0.51 & 0.08 & 2.0 & 0.3 \\
\hline $5-335 G$ & 2.14 & 0.01 & 8.4 & 0.4 & & D. & 3.10 & 0.03 & 1.07 & 0.06 & 0.53 & 0.08 & 2.5 & 0.3 \\
\hline $6-571 G$ & 1.37 & 0.01 & 4.2 & 0.2 & & D. & 1.80 & 0.03 & 0.69 & 0.04 & 0.30 & 0.05 & 1.5 & 0.2 \\
\hline $6-591 \mathrm{G}$ & 2.29 & 0.01 & 7.6 & 0.3 & & & 3.11 & 0.04 & 1.15 & 0.06 & 0.55 & 0.07 & 2.1 & 0.3 \\
\hline $1-9156$ & 2.58 & 0.01 & 18.8 & 0.4 & 38.1 & 1.2 & 4.66 & 0.04 & 1.54 & 0.06 & 0.62 & 0.07 & 2.3 & 0.3 \\
\hline $1-11256$ & 2.19 & 0.01 & 20.6 & 0.4 & 37.3 & 1.4 & 5.83 & 0.05 & 2.01 & 0.07 & 0.78 & 0.08 & 2.7 & 0.3 \\
\hline HR-1B & 2.12 & 0.0 & 4.4 & 0.3 & 18.6 & 1.9 & 2.84 & 0.05 & 1.08 & 0.07 & 0.42 & 0.09 & 2.3 & 0.5 \\
\hline & 2.03 & 0. & 4.6 & 0.3 & 16.0 & 1.5 & 2.83 & 0.05 & 1.05 & 0.07 & 0.51 & 0.08 & 2.4 & 0.4 \\
\hline HR -3B & 1.73 & 0.01 & 4.5 & 0.3 & 14.6 & 1.5 & 2.80 & 0.05 & 0.97 & 0.07 & 0.39 & 0.08 & 2.2 & 0.5 \\
\hline & 1.91 & 0.01 & 4.3 & 0.3 & & 1.4 & 2.71 & 0.05 & 0.98 & 0.07 & 0.50 & 0.08 & 2.7 & 0.4 \\
\hline & 1.97 & 0.0 & 8.9 & 0.3 & 22.6 & 1.5 & 3.34 & 0.05 & 1.14 & 0.07 & 0.44 & 0.08 & 2.7 & 0.6 \\
\hline & 2.01 & 0.01 & 8.6 & 0.3 & & 1.5 & & 0.06 & 1.18 & 0.07 & & & 2.5 & 0.4 \\
\hline HR-12B & 2.93 & 0.01 & 23.2 & 0.5 & 51.3 & 2.0 & 5.64 & 0.09 & 1.84 & 0.08 & 0.43 & 0.07 & 1.4 & 0.4 \\
\hline$W A-2 B$ & 2.82 & 0.0 & 19.2 & 0.4 & 43.4 & 1.6 & 5.20 & 0.07 & 1.74 & 0.08 & 0.61 & 0.07 & 1.8 & 0.5 \\
\hline BV-6B & 2.26 & 0.01 & 6.5 & 0.3 & 19.5 & 1.5 & 3.30 & 0.06 & 1.26 & 0.10 & 0.45 & 0.09 & 3.1 & 1.2 \\
\hline
\end{tabular}

* All concetrations are in parts per million except $\mathrm{Na}$ and $\mathrm{Fe}$ which are expressed as percenatages.

- First number is concentration second number is one standard deviation as determined by counting error. 
TABLE II (CONTINUED)

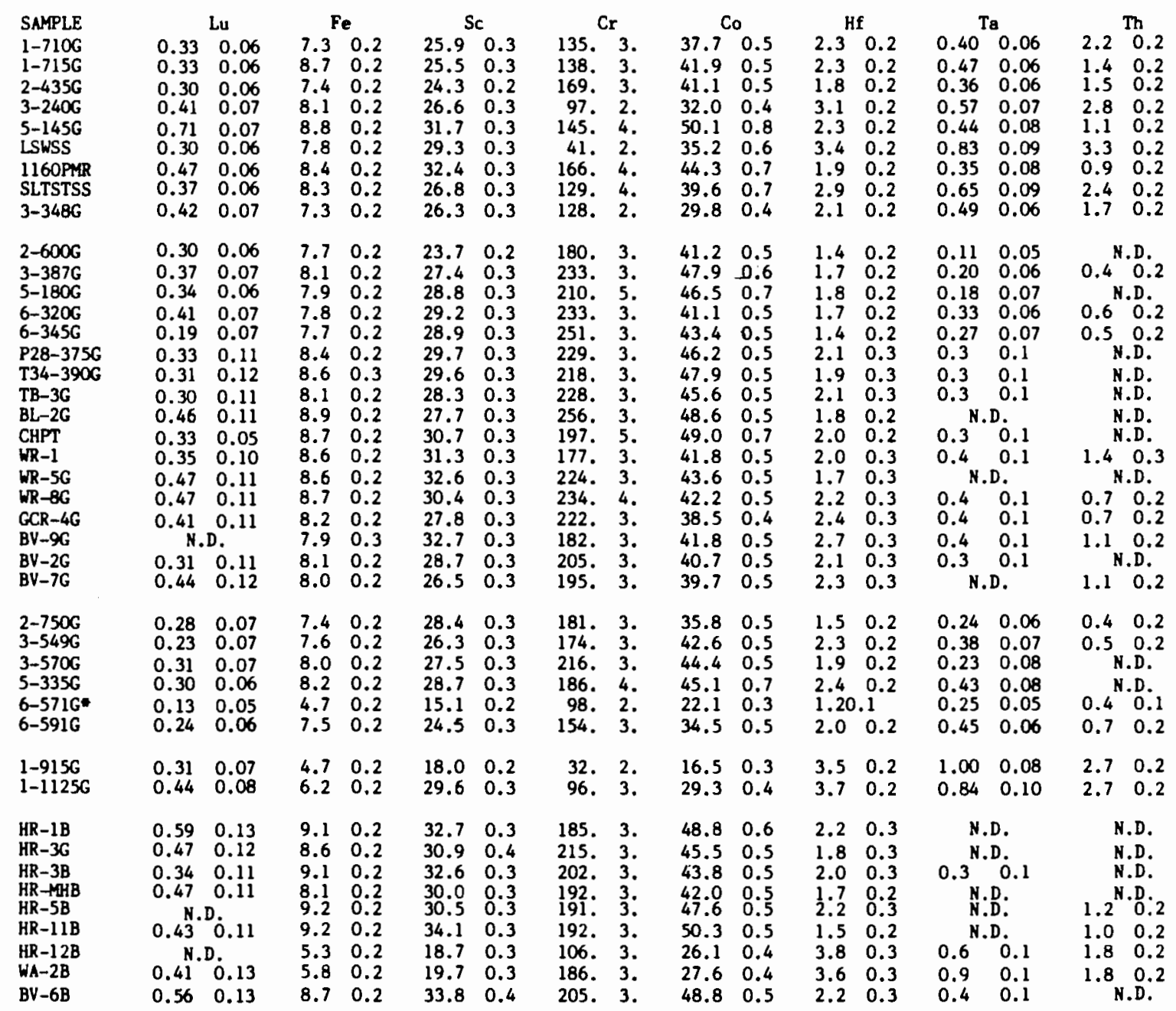




\section{TABLE III}

MAJOR OXIDE CONCENTRATIONS (WEIGHT PERCENT) OF VITRIC SEPARATES AND A HOOD RIVER AREA BASALT

$\begin{array}{lrrrr}\text { Oxide } & \begin{array}{c}\text { Sample } \\ \text { P28-375 }\end{array} & \begin{array}{r}\text { Sample } \\ 6-591\end{array} & \begin{array}{c}\text { Sample } \\ 1-1120\end{array} & \begin{array}{c}\text { Sample } \\ \mathrm{HR} 1\end{array} \\ \mathrm{SiO}_{2} & 51.21 & 52.21 & 53.95 & 50.38 \\ \mathrm{Al}_{2} \mathrm{O}_{3} & 16.99 & 17.00 & 16.56 & 16.81 \\ \mathrm{TiO}_{2} & 1.42 & 1.61 & 2.42 & 1.42 \\ \mathrm{FeO}^{*} & 10.83 & 10.86 & 9.58 & 11.38 \\ \mathrm{MnO} & .17 & .16 & .17 & .17 \\ \mathrm{CaO} & 9.24 & 8.73 & 8.94 & 9.39 \\ \mathrm{MgO} & 7.17 & 8.73 & 4.52 & 8.09 \\ \mathrm{~K}_{2} \mathrm{O} & .02 & .20 & .77 & .13 \\ \mathrm{Na}_{2} \mathrm{O} & 2.61 & 2.79 & 2.48 & 2.16 \\ \mathrm{P}_{2} \mathrm{O}_{5} & .14 & .18 & .42 & .13 \\ \mathrm{FeO}=0.9 \mathrm{Fe}_{2} \mathrm{O}_{3} & & & \end{array}$




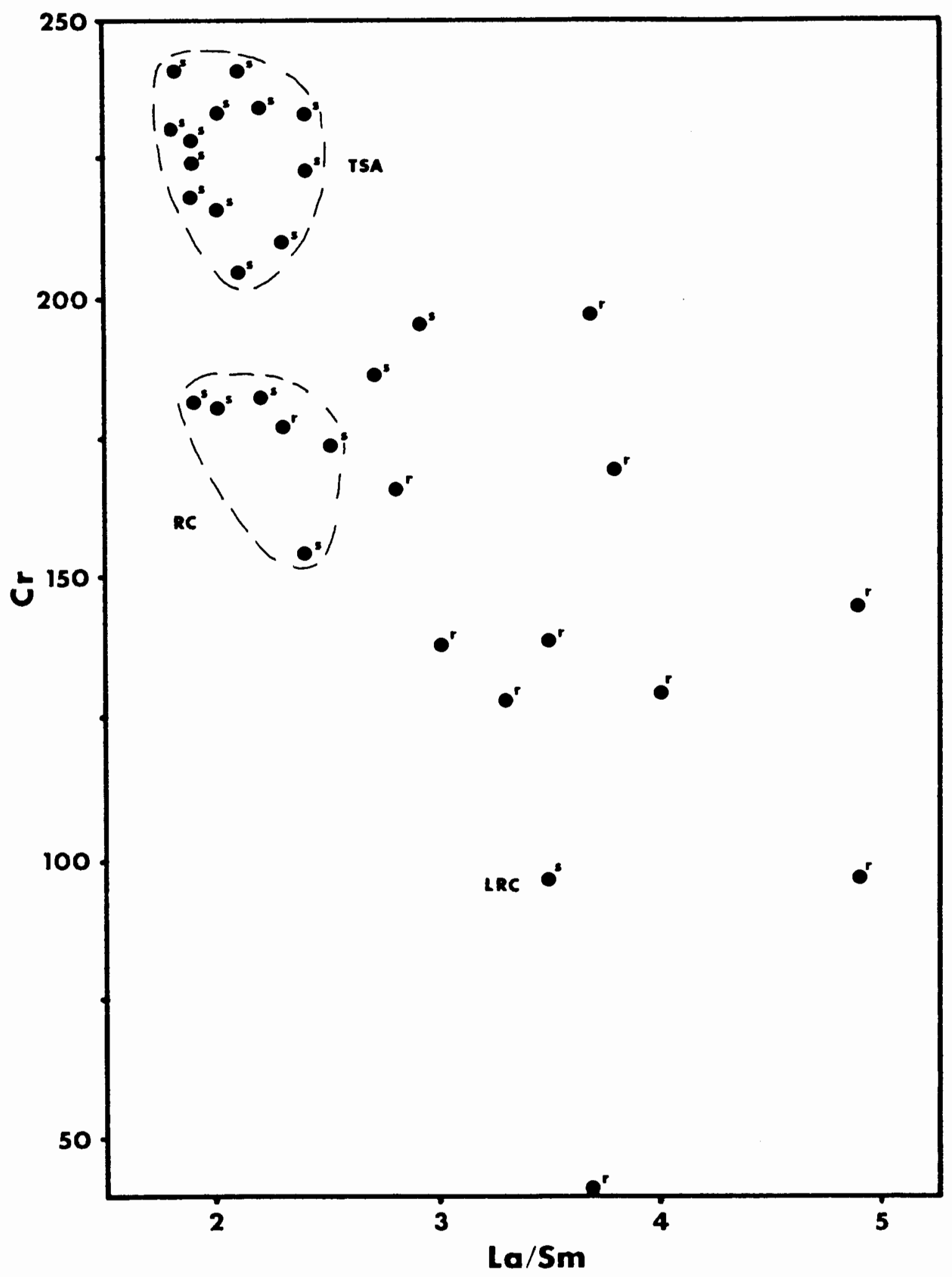

Figure 12. Graph of chromium versus lanthanum/samarium for vitric separates, s; and whole hyaloclastites and lithic sands, $r$. 
similar to the TSA group (Figure 12; Table II). Lithic sands from low in the Sandy River section geochemically resemble the cemented UTSA and upper portions of the TSA, and $1-710 \mathrm{G}$ and $1-715 \mathrm{G}$ from the lower portion of the TSA-RC section in well $1 \mathrm{~N} / 2 \mathrm{E} 29 \mathrm{DA}$.

\section{Discussion of Geochemical Data}

The geochemical variation between upper and lower portions of a single hyaloclastite bed in the RC and TSA are in some cases as great as the difference between the the two groups. Within a single hyaloclastite bed, chromium, cobalt and iron decrease in concentration upwards while hafnium, tantalum, and the rare earth elements increase in their concentration upward. The only exception in the group is sample 6-571G; it is unusually low in all elements; but relative elemental concentrations are similar to the other TSA and RC vitric separates. Two probable sources of geochemical variation in the beds are weathering effects and changes in the source material.

Some of the geochemical variation can be explained by element loss and enrichment during devitrification of sideromelane glass to palagonite. Uppermost beds of the TSA and the UTSA unit show some palagonitization. Typically sodium and potassium are depleted when basaltic glass is altered in low temperature meteoric water to palagonite (Hay and Iijima, 1968). Palagonitization effects probably do not account for the lower chromium concentrations and is rarely the cause of enriched light rare earth elements in fresh water systems (Furnes, 1978). However, the higher La/Sm ratios of the non-vitric separate samples and separates with some weathering rind appears to disagree with Furnes' observation for rare earth elements. 
Dilution by non-hyaloclastite sediment is another possible source of variation. Comparing the distribution of elements in both sediment and sideromelane samples indicates that the degree of dilution required to lower the concentrations of elements such as chromium, scandium, cobalt and iron is incompatable with corresponding enrichment of the rare earth elements and thorium. Figure 10 shows a non-linear trend between Sc and Co for sediments and "vitric" samples in experiment $7 \mathrm{H}$. However, addition of non-high-alumina basalt-derived sediment may account for some of the variation.

Changes in geochemical content of sources as eruptive events proceeded may account for chemical variation between the TSA-RC and UTSA units as well as the presence of beds within the TSA and RC similar to the UTSA. A trend toward enrichment of the rare earth elements, thorium, hafnium and tantalum occurs upward in the TSA and RC along with a decrease in the concentrations of iron, scandium, chromium and cobalt. 
CHAPTER IV

\section{HIGH-ALUMINA BASALTS AND THEIR RELATION \\ TO HYALOCLASTITES}

\section{$\underline{\text { General }}$}

High Cascade basalt flows are distributed throughout the higher elevations and eastern slopes of the Cascade Range and as intracanyon flows and isolated centers on the western side of the Cascade Range (Peck and others, 1964). The Boring Lavas are dispersed eruptive units resulting from local vents in the greater Portland area and the western edge of the northern Oregon and southern Washington Cascade Range (Treasher, 1942; Trimble, 1963; Allen, 1975). Lithologic and stratigraphic similarities show that the Boring Lavas are part of the High Cascades lavas (Peck and others, 1964). Tolan and Beeson (1984) informally applied the name high-alumina basalts to the High Cascades basalts and Boring Lavas found in the lower Columbia River Gorge.

Wise (1969) divided post-Rhododendron Formation High Cascade lavas of the Mount Hood area into three groups based on ages determined by potassium-argon dates, major oxide geochemistry and petrography. Wise's general groupings within the High Cascade Group as modified by Priest (1982) are: (1) lower Pliocene rocks (12(?) to 5 m.y.b.p.), upper Pliocene rocks (5 to $2 \mathrm{m.y.b.p.)}$ ) and (3) Pleistocene to recent rocks including the stratovolcanos of the Cascade Range. Figure 13 shows Wise's (1969) Mount Hood area stratigraphic units as modified by Priest (1982). 


\section{MT. HOOD AREA STRATIGRAPHY}

\begin{tabular}{l|l}
\hline Age & $\begin{array}{l}\text { Mount Hood area } \\
\text { (Wise, 1969) }\end{array}$ \\
\hline 200 yr B.P. & Old Maid mudflow \\
\hline $\begin{array}{l}\text { Less than } \\
700,000 \text { yr B.P. }\end{array}$ & Mount Hood volcanic rocks \\
\hline $\begin{array}{l}\text { About 5 to 2 } \\
\text { m.y. B.P. }\end{array}$ & $\begin{array}{l}\text { Upper Pliocene basalts and } \\
\text { andesites }\end{array}$ \\
\hline $\begin{array}{l}\text { About 12(?) } \\
\text { to 5 m.y. B.P. }\end{array}$ & $\begin{array}{l}\text { Lower Pliocene basalts and } \\
\text { andesites; Laurel Hill and Still } \\
\text { Creek plutons }\end{array}$ \\
\hline $16(?)$ to 12 \\
m.y. B.P. & $\begin{array}{l}\text { Dalles and Rhododendron } \\
\text { Formations }\end{array}$ \\
\hline 16.7 to 14 & \\
\hline m.y. B.P. & Yakima Basalt \\
\hline $\begin{array}{l}\text { Oligocene to } \\
\text { early Miocene }\end{array}$ & \\
\hline
\end{tabular}

Figure 13. Stratigraphic section of the Mount Hood area. From Priest and others (1982) modified after Wise (1969). 
Both the High Cascades Lavas and Boring Lavas are characterized by predominately basaltic lava flows with some andesite, tuff breccias and ash deposits (Peck and others, 1964 and Trimble, 1963). The lavas range from aphyric to diktytaxitic olivine and plagioclase bearing flows. Wise (1969) and other workers (White and McBirney, 1978; Priest, 1982) have described the transition from the "older Pliocene" to "younger Pliocene" lavas as change from basalts and andesites to less voluminous but more basaltic volcanism. Pleistocene to Recent volcanism are described as producing increasingly andesitic and intermediate (dacitic) volcanic rocks (Wise, 1969; White and McBirney, 1978).

INAA geochemical data and major oxide data for hyaloclastites are compared with published and unpublished analyses of High Cascade Lavas to determine possible sources of the Troutdale Formation hyaloclastites. Correlation of hyaloclastites with their eruptive sources could enable extending age dates from dated basaltic sources to the Troutdale Formation or conversely establishing the relative timing of eruptive sources by the stratigraphic sequence of hyaloclastites in the Troutdale Formation.

No attempt is made to use petrography to identify or correlate vitric material with basalts. High alumina-basalts are described as phyric olivine basalts with minor clinopyroxene and orthopyroxene phenocrysts (Wise, 1969).

Geochemical Correlation

Lava samples to be analyzed were collected in the Columbia River Gorge during the fall of 1983 and summer of 1984. A group of samples 
was collected from a pillow-palagonite complex west of Hood River, Oregon that is interpreted to be the result of High Cascades basalt damming the Columbia River (Waters, 1973). Samples were also collected from lavas on the east side of the lower Hood River Valley. Other samples were collected from a flow intercolated with upper Troutdale sediment in the Bridal Veil Channel and from a flow at Prune Hill in Washington, across the Columbia River from Blue Lake Park in northeast Portland.

Geochemical analyses done by other workers include INAA analyses of Boring Lavas (Darolyn Burch, 1980 unpublished INAA data) and published and unpublished trace element and major oxide data for highalumina basalts of the Columbia River Gorge area and the Mount Hood area. Plate 2 is a map showing the locations of basalts for which geochemical data are used in this report. Table II contains INAA data generated in this study.

Specific correlations of the TSA-RC hyaloclastites with individual eruptive centers is not possible because the existing geochemical data do not allow discrimination between specific highaluminia basalts flows of similar geochemistry. In other words, the hyaloclastites can only be correlated with general groups of basalts based on the data available. General correlation can be made based on the geochemical range found in high-alumina basalts and their geographic distribution. Figure 14 has general correlations between the Troutdale Formation hyaloclastic units of the Portland basin and the volcanic source rocks along the Columbia River.

Hyaloclastite units are placed into two geochemical groups for 


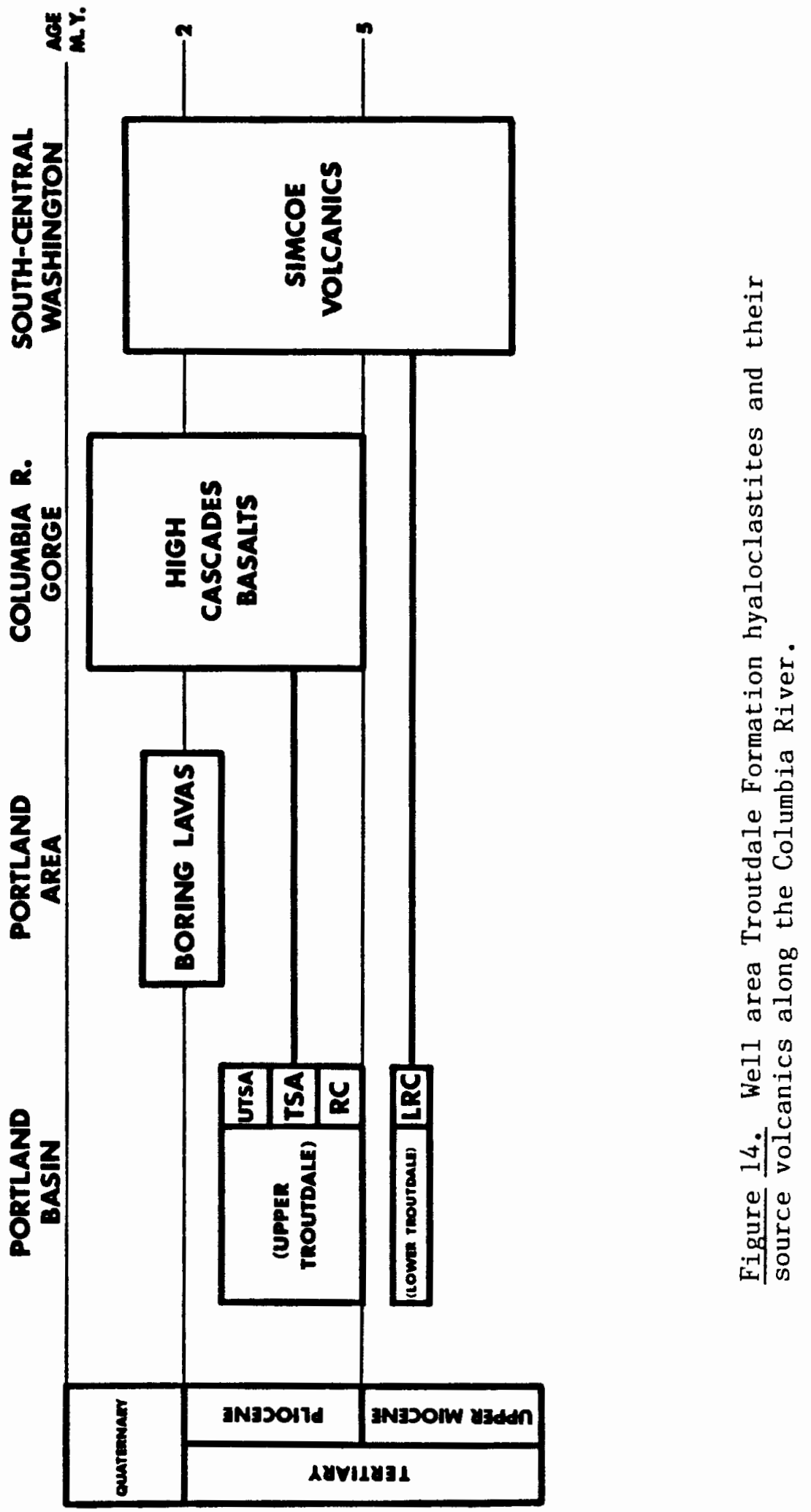


purposes of correlation with basaltic sources. Only vitric separates were used for comparison to potential sources. This was done to avoid geochemical variations of hyaloclastic sediment that could result from weathering and sediment contamination. The TSA-RC geochemical group includes vitric separates from the TSA and RC beds. No vitric separates were available from UTSA beds. The UTSA is assumed to be a continuation of the eruptive events that resulted in the deposition of the TSA beds in the Portland Basin. The LRC geochemical "group" is based on geochemical analysis of one sample from well hole 1N/2E 29DA showing vitric material unique from the TSA-RC group. The two main well area hyaloclastite units, the TSA and RC, are essentially equivalent and account for the bulk of the hyaloclastite material of the well area. The LRC is vitric material separated from a basaltic glass-bearing sandy gravel and represents a very small percentage of the total vitric material of the well area.

In outcrop, the hyaloclastites of the upper member of the Troutdale Formation are equivalent to the well area TSA and RC hyaloclastite units. TSA-RC equivalent units have been correlated from the Portland Basin to the Bridal Veil Channel (Figure 2; Plate I) where there is approximately 200 feet of TSA-RC equivalent material below the intercolated high-alumina basalt flow. Above the high-alumina basalt flow the upper member becomes coarser, with bouldery, gravelly channellike features and coarse lithic and vitric sands. Surface exposure of the LRC is not known to exist.

When hyaloclastite trace element geochemistry is compared to the available trace element data from high-alumina basalts of the Portland, 
Oregon City, and Columbia River Gorge areas, a pattern emerges. Hyaloclastites of the TSA-RC unit are grouped together rather tightly compared to the rest of the basalts (Figure 15, Figure 16, and Figure 17) and are gathered at one end of the total high-alumina basalt group. The hyaloclastites of the RC-TSA are more primitive than most of the high-alumina basalts of the Portland area and basaltic cones along the lower Columbia River Gorge. The lower lanthanum to samarium ratios (light to heavy rare earth elements), low thorium, and higher cobalt, iron and scandium set the TSA-RC vitric separates apart from most of the lavas in the High Cascades Group of northern Oregon and southern Washington. Plots of lanthanum/samarium versus cobalt (Figure 15 and Figure 16) and lanthanum to samarium versus lanthanum (Figure 17) illustrate this characteristic. Lanthanum versus samarium ratios, an indicator of light rare earth fractionation, are among the lowest found in the data examined.

Major oxide geochemical data follow a trend similar to the trace element data. TSA-RC samples appear to be relatively primitive basalts of the High Cascades Group. The hyaloclastites of the TSA-RC are basaltic in composition based upon a $53 \% \mathrm{SiO}_{2}$ limit between basalt and andesite (Priest and others, 1983) and 53.5\% SiO 2 based on white and McBirney (1978). Figure 18, a plot of $\mathrm{FeO} / \mathrm{MgO}$ versus $\mathrm{SiO}_{2}\left(\mathrm{FeO}^{*}=\mathrm{FeO}\right.$ $+.9 \mathrm{Fe}_{2} \mathrm{O}_{3}$ ) as described by Miyashiro (1974) shows the TSA-RC units near the end of the basalt group trend near the calc-alkalinetholeiitic boundary. The $\mathrm{FeO} / \mathrm{MgO}$ versus $\mathrm{SiO}_{2}$ graph shows the hyaloclastites of the TSA-RC to be within the younger Pliocene basalt field of Priest and others (1982) based on data from Wise (1969). 


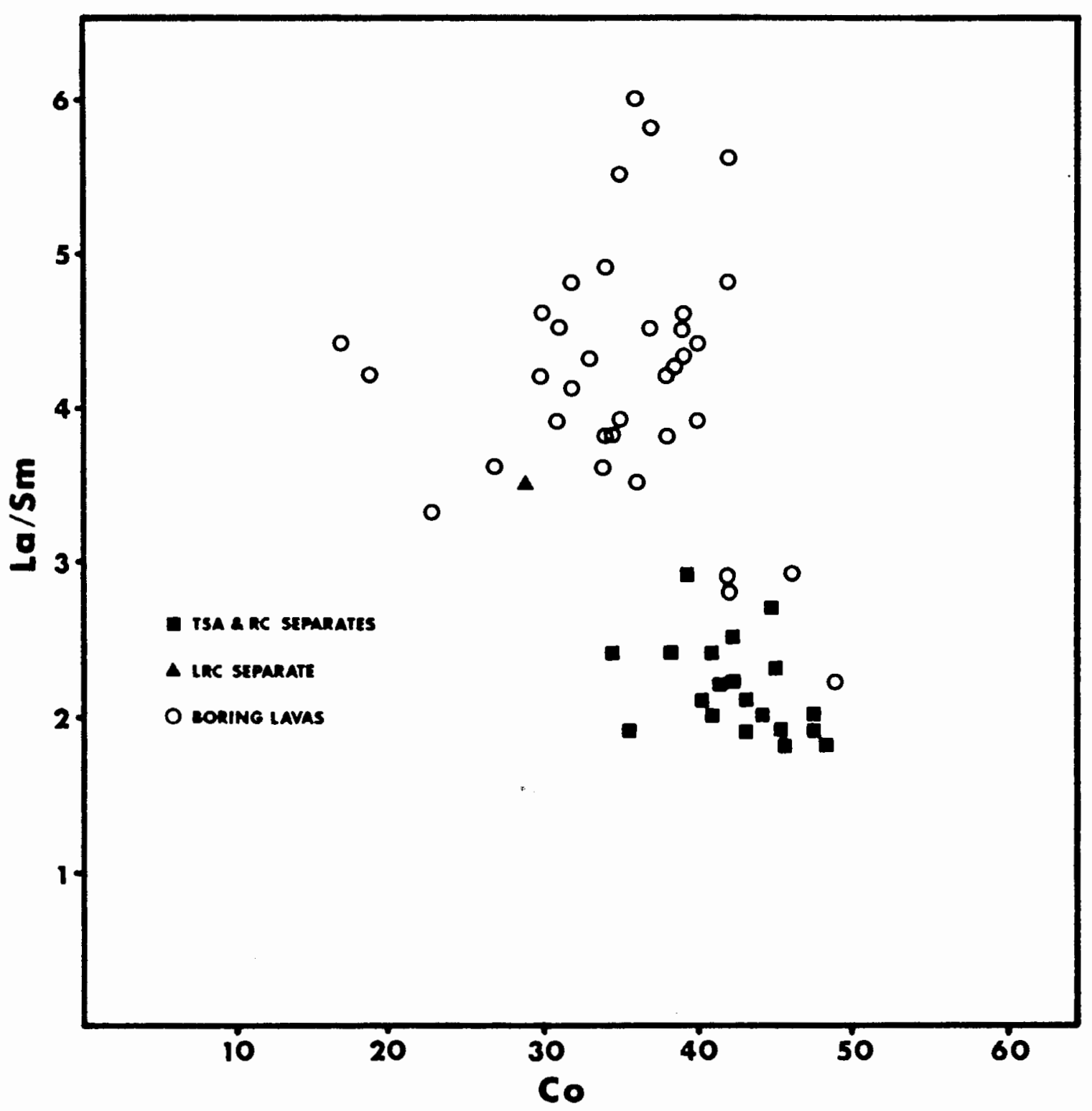

Figure 15. Lanthanum/samarium versus cobalt for Troutdale Formation vitric separates and Boring Lavas of the Portland area. Boring Lava data from (Darolyn Burch, 1980 unpublished manuscript). 


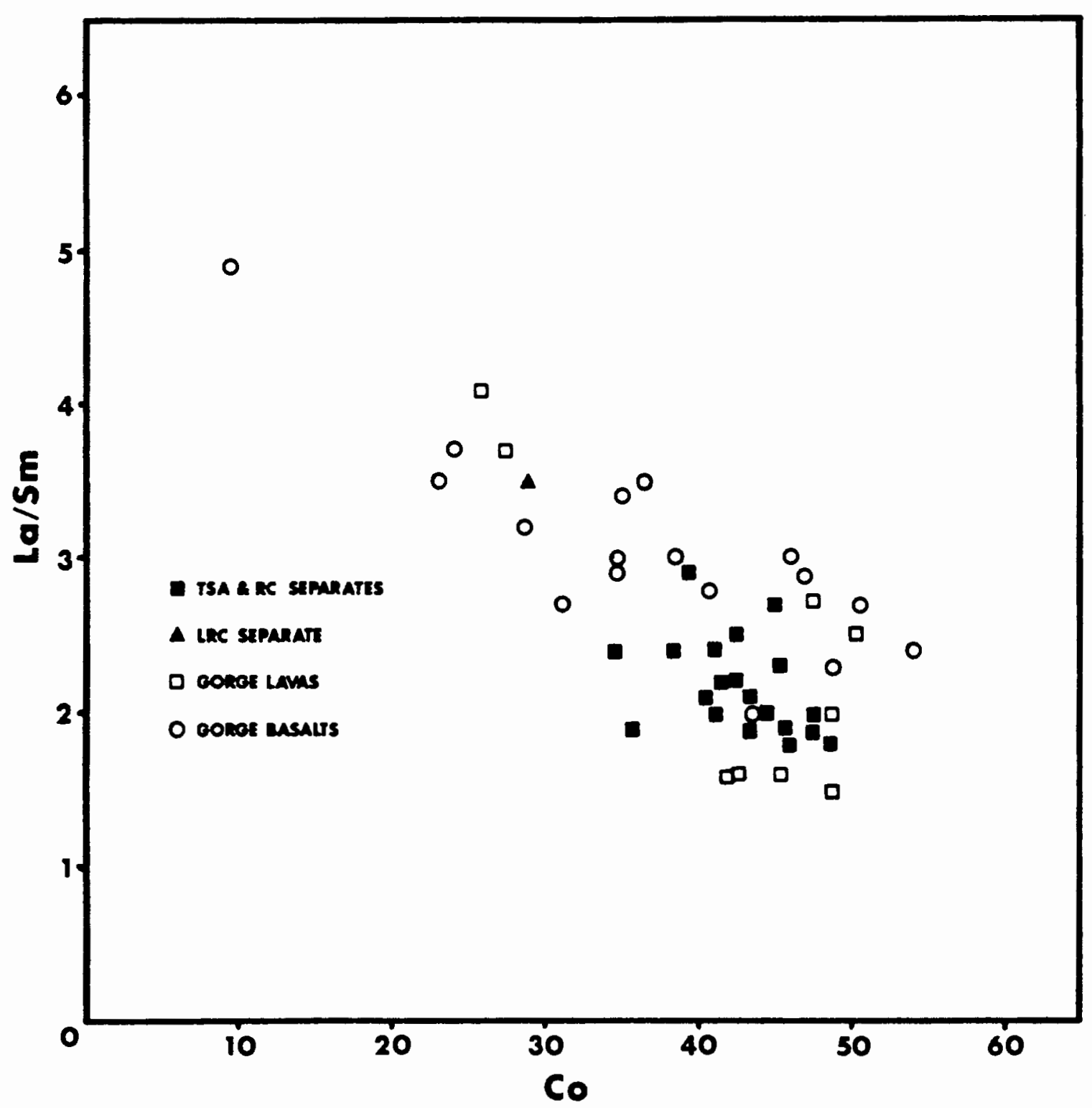

Figure 16. Lanthanum/samarium versus cobalt for Troutdale Formation vitric separates, Columbia River Gorge area high-alumina lavas, and lower Columbia River Gorge area high-alumina basalts. Gorge basalt data from Hammond and Korosec (1983). 


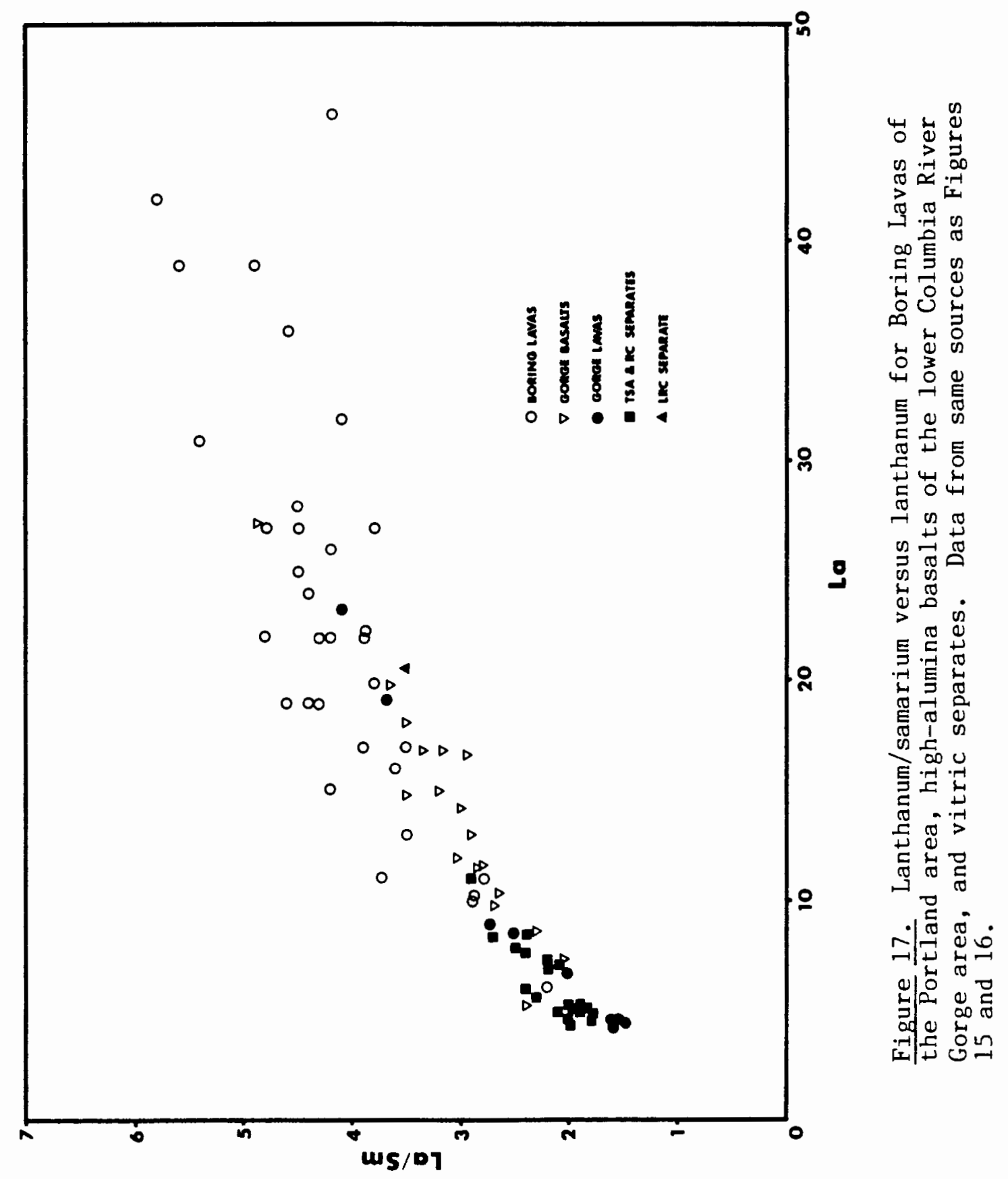




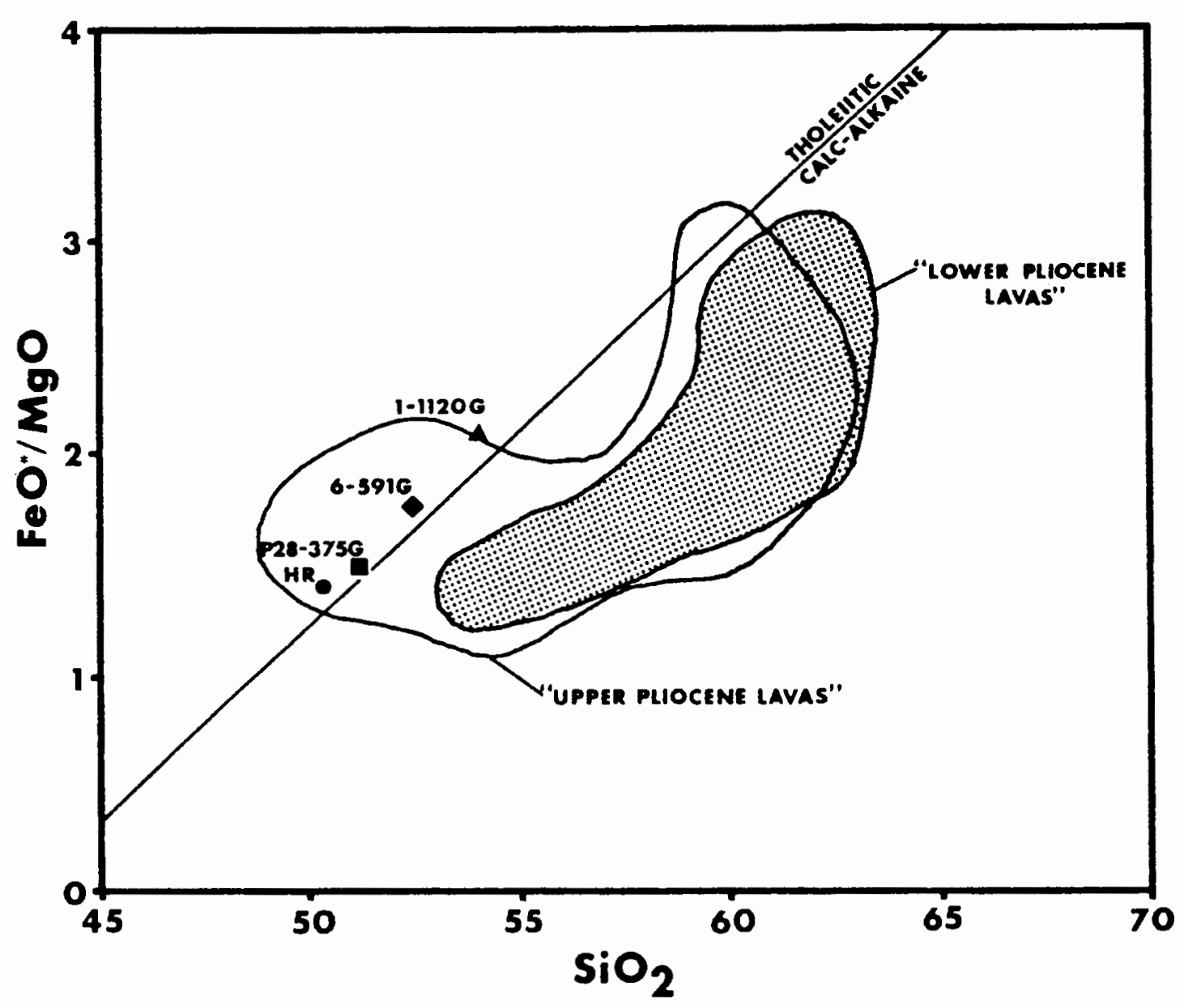

Figure 18. $\mathrm{FeO} * \mathrm{MgO}$ versus $\mathrm{SiO}_{2}$ for vitric separates and Hood River palagonite complex basalt. Fields of upper and lower Pliocene lavas from Priest and others (1982) using data from Wise (1969). 
The LRC vitric separate sample is unique from all analyzed High Cascades Group lavas in Northern Oregon (Wise, 1969; Tolan and Beeson, 1984; Gannett, 1982; Priest, 1982). It is set apart by much higher titania $\left(\mathrm{TiO}_{2}\right)$ content $(2.42 \%)$ and relatively high $\mathrm{P}_{2} \mathrm{O}_{5}$ content (.42\%). The LRC sample is, with $53.9 \% \mathrm{SiO}_{2}$, on the border between basaltic and basaltic andesite. In appearence the LRC sample is no different than the other unweathered hyaloclastic material.

The LRC's stratigraphic position 300 feet below the TSA-RC beds in the well area and its unique geochemistry indicate that it is probably from an eruptive source distinct in origin and time from those of the TSA-RC hyaloclastites. Comparison of the one major oxide analysis of the LRC glass sample to available data from the Columbia River Gorge and the northern Oregon and southern Washington Cascade Range leads to a tentative correlation with two flows (4.5 and 7.5 m.y.b.p.) in the Simcoe Volcanics (James Anderson, 1985 written communication). Figure 19, $\mathrm{TiO}_{2}$ versus $\mathrm{P}_{2} \mathrm{O}_{5}$ shows a separation of the LRC, and Simcoe Volcanics basalts similar to the LRC, from the TSA, RC, Columbia River Gorge and Mount Hood area basalts. It is possible that LRC glass is from a source outside the immediate area of the ancestral Columbia River. McBirney and White (1982) described Pliocene volcanism in central and eastern Oregon and southwestern Idaho that could produce basalts similar to the LRC glass.

The basaltic composition of the TSA-RC hyaloclastite units argues that a source area should contain primarily basaltic rocks. Other limiting geochemical criteria are the very low potassium (.02\% to $.20 \%$ $\mathrm{K}_{2} \mathrm{O}$ ), low $\mathrm{FeO}^{*} / \mathrm{MgO}$ ratios, and rare earth element concentrations ( $5 \mathrm{ppm}$ 


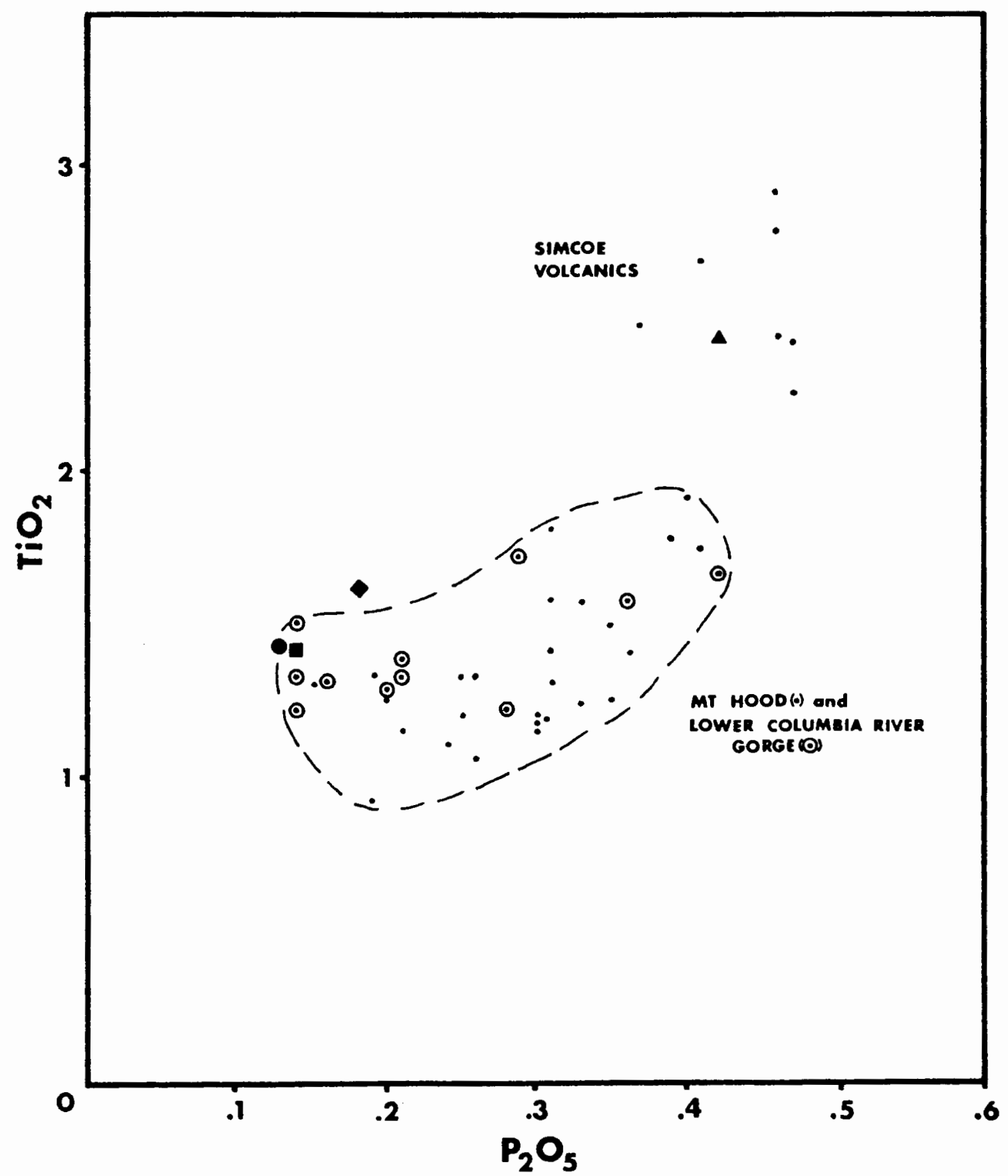

Figure 19. $\mathrm{TiO}_{2}$ versus $\mathrm{P}_{2} \mathrm{O}_{5}$ comparing vitric separates to fields of Wise's (1969) Pliocene basalts; and lower Columbia River Gorge highalumina basalts of Tolan and Beeson (1984) and Goff (1977), ○; and Simcoe volcanics basalts (Anderson, 1985 written communication). Vitric separate symbols as in Figure 18. 
La, <.05 ppm Th) of the TSA-RC units. Very few available analyses show rocks with such low concentrations of these incompatible elements.

Examination of the most thorough study of the northern High Cascades lavas in the Mount Hood area (Wise, 1969), indicates that few of the eruptive centers examined by Wise (1969) are dominated by basaltic rocks. Those eruptive centers that are primarily basaltic are grouped stratigraphically within the "upper Pliocene" rocks with $\mathrm{K}-\mathrm{Ar}$ ages between 4 and 2 m.y.b.p. (Figure 13, 5-2 m.y.b.p. Priest, 1982). Two areas in which predominantly basaltic rocks were found are Lookout Mountain on the east side of the Hood River fault, east of the Hood River Valley and in the Bull Run area (Wise, 1969). These lavas are not as characteristically low in $\mathrm{K}_{2} \mathrm{O}$ as the TSA-RC appear to be. They may represent similar or contemporaneous lavas to those that are the source of the TSA-RC hyaloclastites.

Basalts along the Columbia River Gorge near the city of Hood River, Oregon are most similar to the TSA-RC hyaloclastites. These include basalt and glass taken from the pillow-palagonite complex near the base of Mount Defiance and lava from near the base of Underwood Mountain and Beacon Rock. Basalts east of the palagonite complex (Goff, 1977) at the West Hood River exit and Panorama Point, southeast of Hood River are similar to, if not exactly the same as the vitric units. Also, several very low $\mathrm{K}_{2} \mathrm{O}$ basalts were found among highalumina basalts sampled in the Columbia River Gorge by Tolan and Beeson (1984). These were flows overlying or interbedded with upper member Troutdale Formation.

Beeson and Moran (1979) stated that the Hood River Mount Defiance 
basalts dip 10 degrees eastward toward the Hood River Fault. The Hood River Fault has been dated as post 3 m.y.b.p. (Beeson and Moran, 1979) because it offsets and displaces upper Pliocene basalts that were potassium-argon age dated at 3 m.y.b.p. by Wise (1969) on Lookout Mountain. Beeson and Moran estimated the age of these eruptions to be near to 3 m.y.b.p., however, they could be older. Hammond and Korosec (1983) list chemical data and potassium-argon age dates for highalumina basalts similar to the TSA-RC in the Indian Heaven area of the southern Washington Cascade Range. An age of $3.7 \mathrm{m.y.b.p.} \mathrm{is} \mathrm{assigned}$ to the basalt of Thomas Lake. While these basalts may not be suggested as sources for the TSA-RC hyaloclastic debris, the Indian Heaven basalts illustrate the geographic extent of volcanism similar to that which produced the TSA and RC units.

To summarize, the basaltic glass clasts that compose the hyaloclastite beds of the TSA and RC found in the well area and the upper member Troutdale Formation found along the Sandy River and the in the Bridal Veil Channel are derived from "upper Pliocene" High Cascade Group basalts that were erupted between the Hood River Valley and the lower Columbia River Gorge. The age of these basalts based on the nomenclature of Wise (1969) modified by Priest (1982) is between 5 m.y.b.p. and 2 m.y.b.p. The age of Hood River area basalts that are correlable with the TSA-RC is estimated to be between 5 and 3 m.y.b.p. (Beeson and Moran, 1979; Marvin Beeson, 1986 personal communication). The LRC vitric material is similar to basalts in the Simcoe Volcanics with ages ranging from 7.5 m.y.b.p. to $2(?)$ m.y.b.p. The LRC is separated from the base of the TSA-RC beds in the well area by 
approximately 300 feet suggesting that timing of 7 to $3 \mathrm{~m} \cdot \mathrm{y} \cdot \mathrm{b} \cdot \mathrm{p}$. for deposition of the LRC unit and 5 to $3 \mathrm{~m} \cdot \mathrm{y} \cdot \mathrm{b} \cdot \mathrm{p}$. for deposition of the TSA-RC unit are not unreasonable. 


\section{CHAPTER V}

STRUCTURAL DEFORMATION OF THE TROUTDALE FORMATION

Lack of recognizable stratigraphic horizons and limited areas of exposure have hindered perception of structural deformation within the Troutdale Formation and the Sandy River Mudstone. The Sandy River Mudstone, and lower and upper members of the Troutdale Formation have been described by most workers as relatively undisturbed sediment filling a westward deepening basin in the Portland area. General eastward thinning of the Troutdale Formation and eventual disappearence of Troutdale Formation sediment toward the crest of the Cascade Range is noted by several authors (Barnes and Butler, 1930; A1len, 1932; Lowrey and Baldwin, 1952; Hodge, 1938; Trimble, 1963) (Figure 20). Trimble (1963) used the transition of Sandy River Mudstone to Troutdale Formation as a stratigraphic and structural marker. Using this marker, he found regional dips of about two degrees westward into the Portland Basin (Figure 21).

A more detailed stratigraphic interpretation of the Troutdale Formation in the lower Columbia River Gorge and Portland area is allowed by the recognition of stratigraphic upper and lower members (Tolan and Beeson, 1984) within the ancestral Columbia River facies. Delineation of the TSA, UTSA and RC hyaloclastite units as a marker horizon within the Portland basin further refines the stratigraphy of the Troutdale Formation for use in structural interpretation. Along the Sandy River, Trimble's (1963) Sandy River Mudstone-Troutdale 


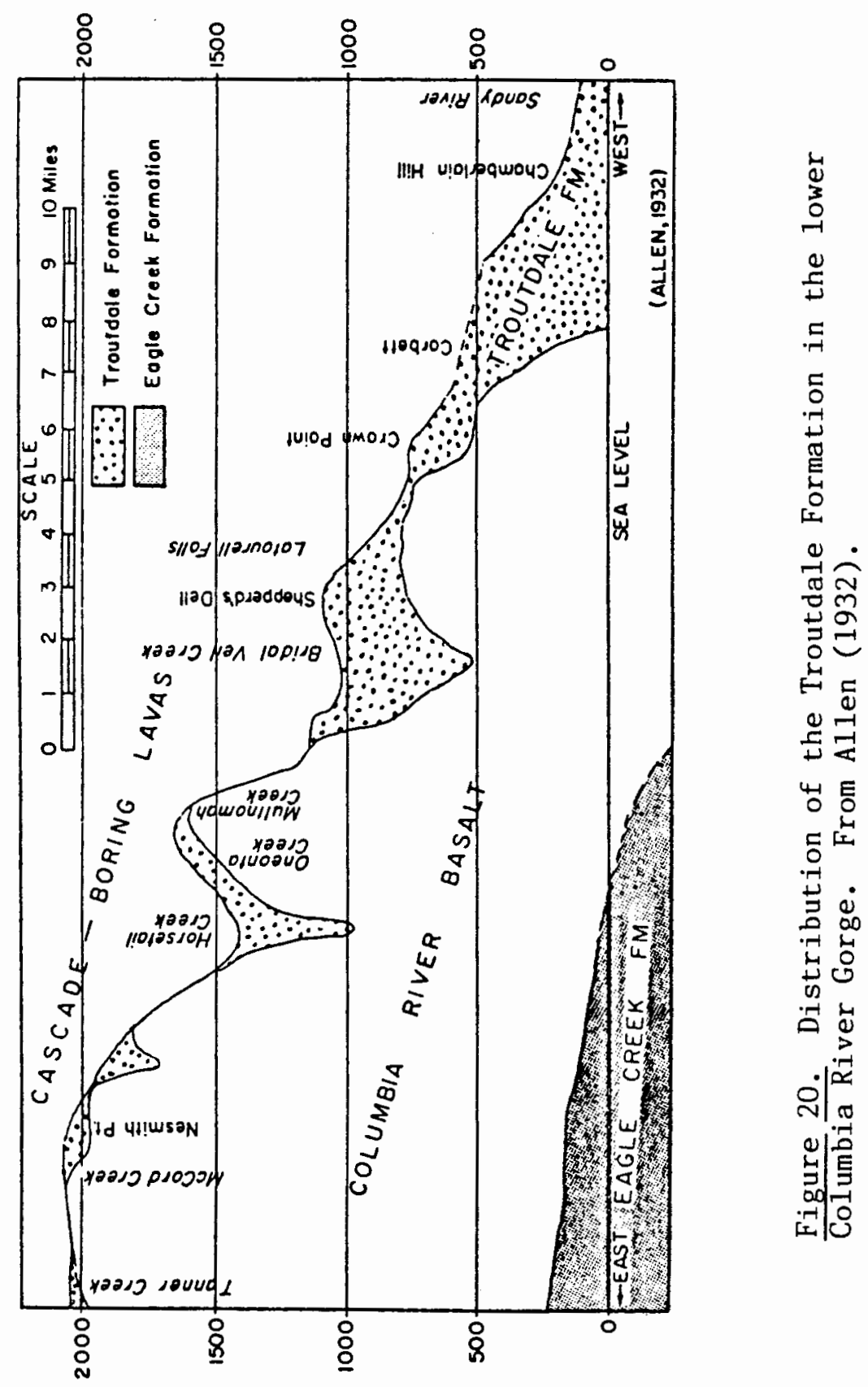




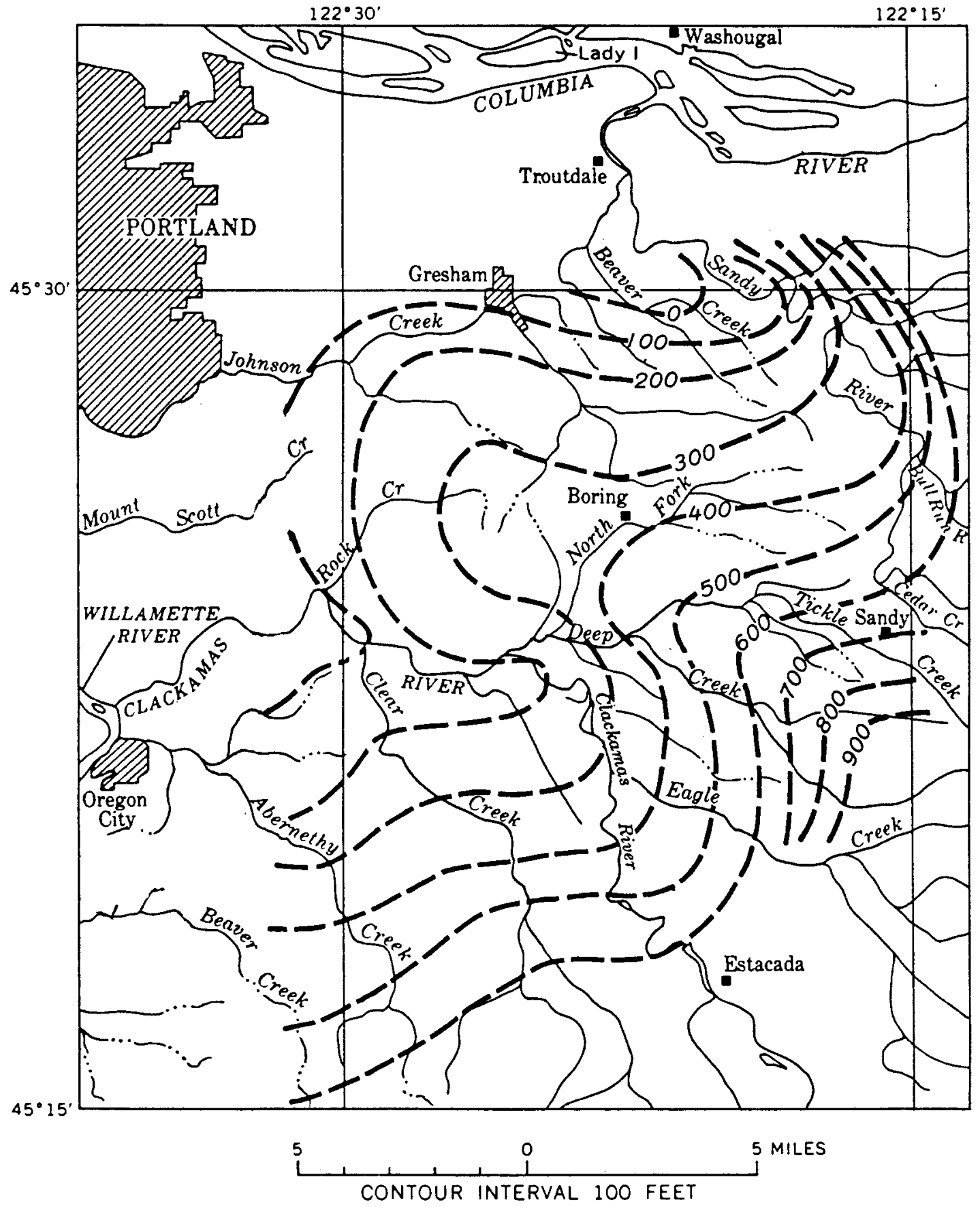

Figure 21. The elevation of the Sandy River Mudstone-Troutdale Formation contact as mapped by Trimble (1963). Modified from Trimble (1963). 
Formation contact appears to be equivalent to Tolan and Beeson's (1984) lower to upper Troutdale Formation transition in the Bridal Veil channel. Within the well area the upper member Troutdale Formation hyaloclastic beds define an interval within the muds, sands and gravels of the Troutdale Formation and Sandy River Mudstone equivalent sediments.

Based on the distribution of the upper Troutdale Formation hyaloclastite beds in the lower Columbia River Gorge the relative uplift between the Portland basin and Cascade Range along the Columbia River Gorge can be determined. About 800 feet of uplift is found between the the mouth of the Sandy River area and the Bridal Veil channel 10 miles to the east. Wells in the easternmost portion of the well area show the base of the RC to be at about -500 feet (wells: $1 N / 3 E 31 \mathrm{CD}, 1 \mathrm{~N} / 3 \mathrm{E} 20 \mathrm{CB} 2$ ), approxinately 550 feet lower than exposed equivalents near the mouth of the Sandy River 4 miles to the east. The Troudale Formation and Sandy River Mudstone appear to dip shallowly westward from the Sandy River area to the eastern margin of the well area (Figure 22). The cross-section in Figure 22 is based upon exposures along the Sandy River and the stratigraphy within the well area. The uppermost hyaloclastite units are truncated by the overlying Troutdale Formation gravels in the eastern part of the the well area. This may indicate that the western portion of the well area was moving downward relative to the eastern portion at the time the latest Troutdale Formation sediments were being deposited (Figure 22). Deformation of the sediments is inferred (Trimble, 1963) to be the result of post-depositional uplift in the Cascades and possibly 

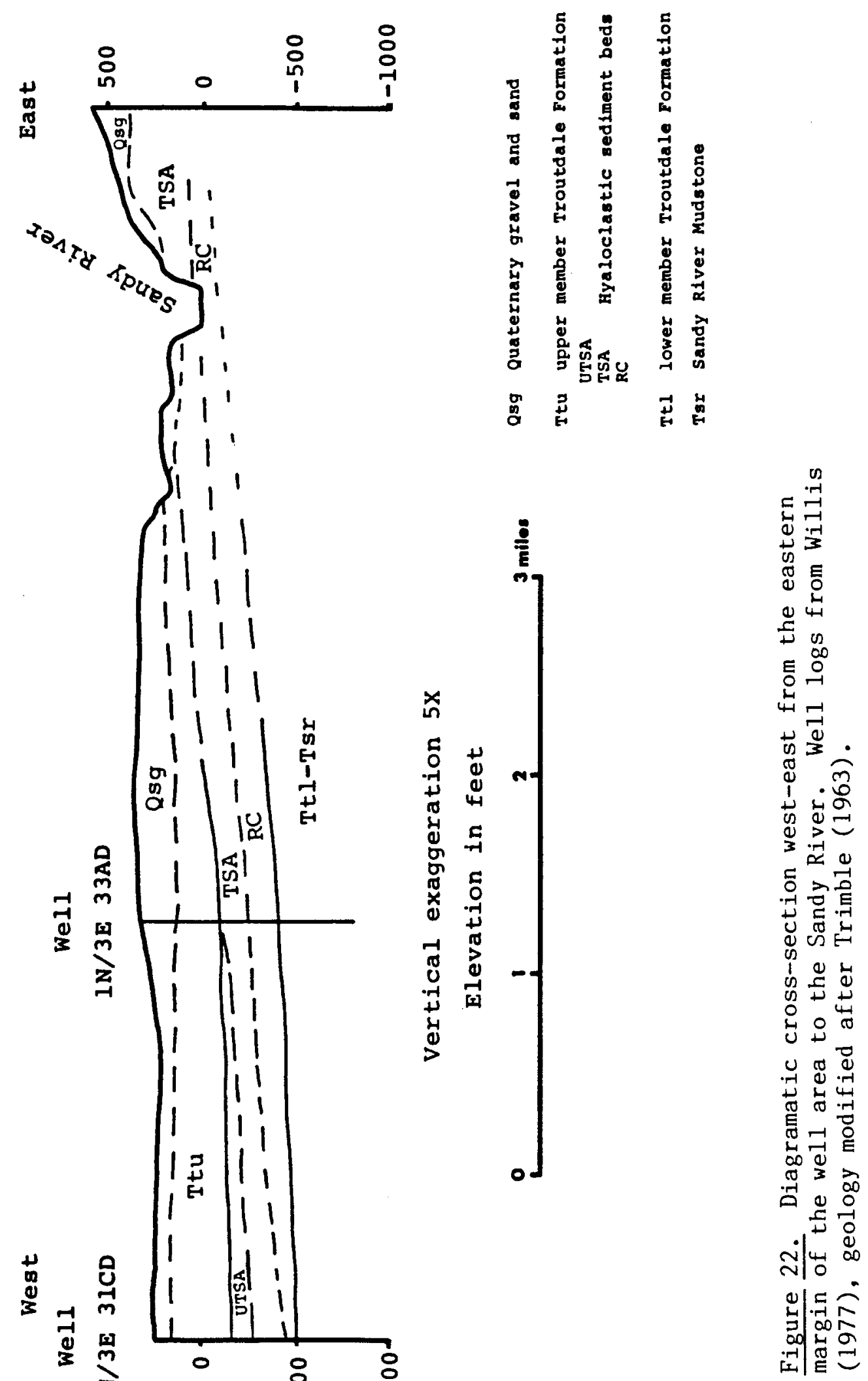
some downwarping of the synformal structure of the Portland basin during deposion of the sediments. Beeson and others (1985), working with Columbia River Basalt Group stratigraphy, interpret the Portland Basin to be a pull-apart basin caused by right-lateral wrench faulting related to the Portland Hills-Clackamas River Fault Zone, active since at least middle Miocene time. The shallow basin that collected the Troutdale Formation and Sandy River Mudstone extends east of the Sandy River into what is now the western foothills of the Cascade Range. While the current rhomoidal Portland basin appears to be a more recent occurrence.

A monoclinal fold with a northwesterly axis is located between the well area near Blue Lake and Prune Hill, northwest of Camas, Washington. This structure postdates the upper Troutdale Formation hyaloclastic beds and may be associated with the formation of the currently existing Portland basin. Beds of TSA equivalent hyaloclastite, dipping 10 to 15 degrees to the southwest, form cuestalike ridges at Taggart Bluff on the south shore of the Columbia River and along the south shore of Blue Lake. Reconnaissance mapping in the Prune Hill area identified an approximately 200-foot section of nearly flat-lying fluvial hyaloclastic sediment and gravelly vitric sand, exposed between elevations of 450 feet to 650 feet on the south side of Prune Hill that are lithologically similar to the TSA sediment of the well area.

A cross-section through this area shows a monclinal fold with beds truncated by the Columbia River (Figure 23). Davis (1986 unpublished Portland State University masters thesis manuscript) 


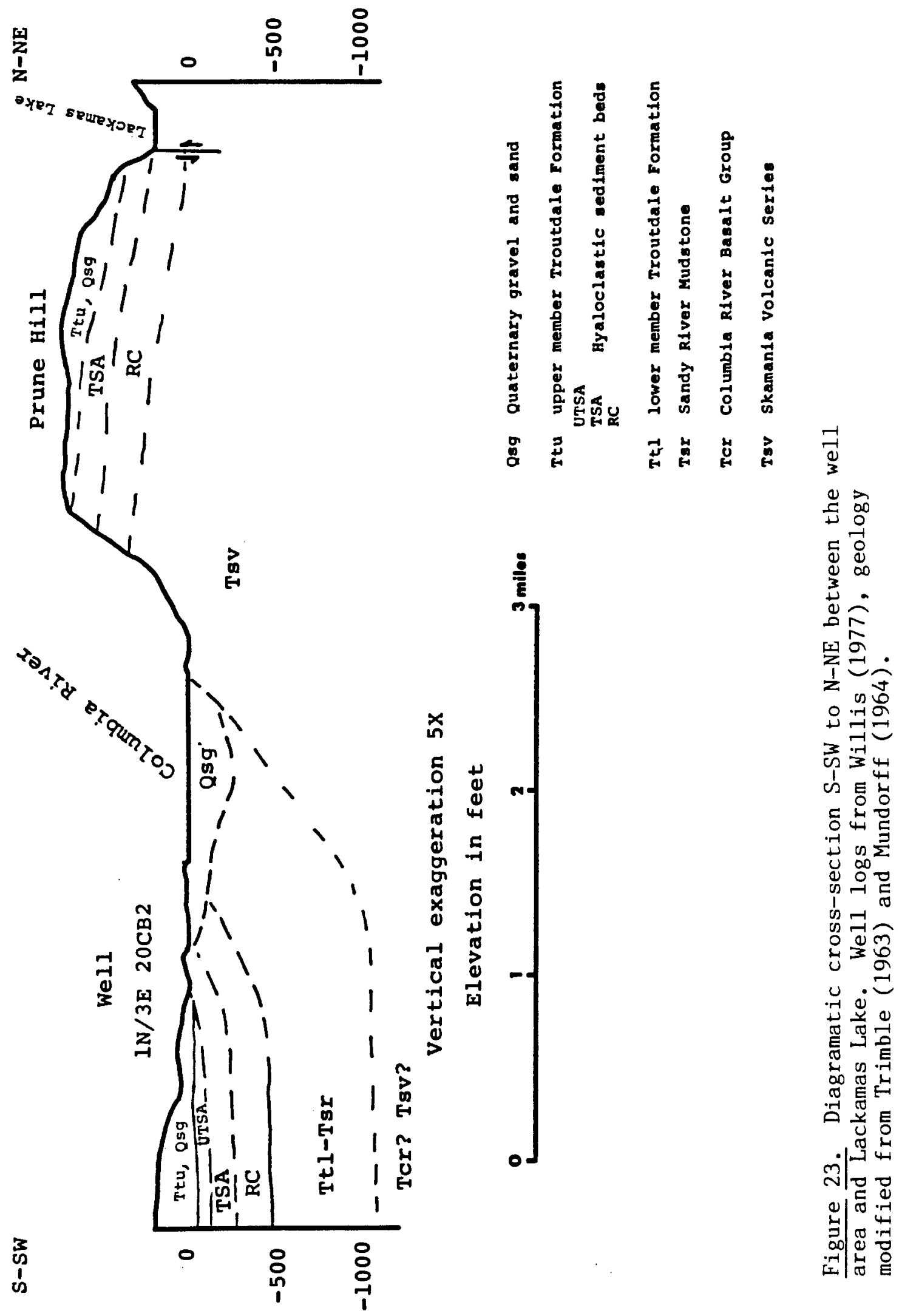


performed a gravity survey across the northwest-southeast-trending Lackamas Lake lineament. Using the large density difference between the Troutdale Formation and the underlying Columbia River basalts and Skamania Volcanics Davis modeled several northwest-trending block faults which cut the Columbia River basalts and presumably overlying Troutdale Formation and Sandy River Mudstone near the eastern border of the Portland basin and along the Lackanas Lake lineament. Displacements are estimated to be up to 400 feet (Davis, 1986). The 400 to 500 foot displacement of the upper Troutdale Formation between the well area and Prune Hill agrees with the magnitude of this probable fault displacement.

The Blue Lake-Prune Hill deformation near the northeast margin of the Portland Basin may be associated with the eruption of the Boring Lavas in the Portland area. Beeson and others (1975) suggest that Boring Lava volcanism in the Portland area is related to deformation along the Portland Hills fault. Available potassium-argon age dates for Boring Lavas of $2.6 \mathrm{m.y.b} . \mathrm{p}$. for the Oregon City plateau and 1.3 m.y.b.p. at Rocky Butte (Norman MacLeod, Robert Duncan, and Edwin Mckee, 1985 written communication,) suggest that these rocks were erupted in the very latest Pliocene to early Pleistocene.

This study finds that the Portland basin has been tectonically active during and after the deposition of the Sandy River Mudstone and Troutdale Formation. The basin appears to have thickened to the west as upper Troutdale Formation sediment accumulated in the late Pliocene(?). Post TSA-RC displacement defines the northeastern margin 
of the Portland basin in its current form. Several hundred feet of deformation is seen in the hyaloclastic beds of the upper member Troutdale Formation between the well area south of Blue Lake and exposures of equivalent strata across the Columbia River at Prune Hill. More gradual deformation is seen between the well area and the Troutdale Formation along the lower Sandy River area. 


\section{CHAPTER VI}

\section{LATE CENOZOIC GEOLOGIC HISTORY OF THE PORTLAND BASIN}

\section{Outcrop patterns mapped by Trimble (1963) and Tolan (1982)}

suggest that the Columbia River Basalt Group lava flows were deposited around hills of the older Eocene to Miocene Skamania Volcanics.

Columbia River basalt flows apparently entered the Portland area via a trough in the northern Oregon Cascades (Beeson and Moran, 1979). Flows passed through western Oregon and into the shallow marine sediments of the Miocene northern Oregon coast (Beeson, Perttu and Perttu, 1979).

Trimble (1963) interpreted 400 feet of rock, logged at the bottom of the Ladd Well in southeast Portland, to be Columbia River basalt. A well drilled for the City of Fairview encountered basalt interpreted to be Columbia River basalt at -670 feet elevation and other rocks interpreted to be pre-Columbia River basalt rocks (Foxworthy and others, 1964). The youngest Columbia River Basalt Group flow mapped in western Oregon is the Pomona flow which occurs as an intracanyon flow patially filling the Bridal Veil channel of Tolan and Beeson (1984). This channel, was cut into older Columbia River Basalt Group flows (Tolan and Beeson, 1984). Deformation of the Columbia River basalts was occurring in the Portland area at the time of basalt deposition, but little sediment accumulation occurred (Beeson and others 1975; Beeson and others, 1985).

As Columbia River basalt volcanism ended in late Miocene time, deformation continued. Muds and sandy muds equivalent to the lower 
member of the Troutdale Formation and the Sandy River Mudstone accumulated in a basin which apparently extended from the eastern base of the Tualatin Mountains to east of the present-day Sandy River. At the same time in the Cascade Range, an ancestral Columbia River deposited sandy gravels in the confined canyon of the Bridal Veil channel. Also, at this time, volcaniclastics equivalent to the upper Rhododendron Formation were deposited within the lower member Troutdale Formation in the Bridal Veil Channel. No Rhododendron Formation volcanic units are found in the well area sediments.

The hyaloclastic debris-bearing gravel LRC bed is the first evidence of Pliocene high-alumina-volcanism-derived sedinent deposited in the Portland basin. Vitric material from the LRC bed (sample 1$11256)$ is derived from lavas of the Simcoe Volcanics, 7 to 2 m.y.b.p., in the Goldendale, Washington area.

Cascadian high-alumina basalts erupted during the early Pliocene (5 to 2 m.y.b.p.) interacted with the ancestral Columbia River to form the fluvially deposited hyaloclastites of the RC, TSA and upper TSA units. Basalts sinilar to the TSA-RC hyaloclastites are found in an area from the Hood River Valley to the Bull Run area. A high-alumina basalt flow with chemistry similar to the TSA-RC is found within the upper member Troutdale Formation at Bridal Veil. An exposed pillow palagonite complex along Interstate Highway 84 just west of the city of Hood River, Oregon suggests interaction of lava with a lake (Waters, 1973).

After the uppermost hyaloclastite beds were deposited, another episode of deformation took place. Upper Troutdale Formation sediment 
consisting chiefly of gravels that are mixed Columbia River sediment and volcanic lithic clasts apparently derived from the Cascade Range accumulated to at least what is now about 600 to 700 feet elevation in the Portland area. Rocky Butte, Mount Tabor, Kelly Butte and Powe11 Butte all are partially composed of post hyaloclastite gravels recognized to be Troutdale Formation (Trimble, 1963; Treasher, 1942). Reconnaissance mapping of Troutdale Formation outcrops in the Lackamas Lake-Prune Hill area, Washington indicates that 400 to 500 feet of downward displacement has occurred within the upper Troutdale Formation between Prune $\mathrm{Hill}$ and the Blue Lake area. The rectangular shape of the Portland Basin as it exists today appears to be the result of this period of tectonic activity.

A period of erosion appears to have followed deposition of the Troutdale Formation sediments and preceded eruption of the Portland area high-alumina basalts (Boring Lavas). Lavas near Prune Hill, Washington are at lower elevations than near-by upper member Troutdale Formation hyaloclastites. A similar example is found on the west of Rocky Butte.

An approximate upper age of under $2 \mathrm{~m} \cdot \mathrm{y} \cdot \mathrm{b} \cdot \mathrm{p}$. is placed on the Troutdale Formation based on the stratigraphic relationship between the Troutdale Formation and Boring Lava vents in the Portland area. Boring Lavas intrude and apparently have deposited scoria and ash within or on the Troutdale Formation at Rocky Butte, Mount Tabor, Kelly Butte and Powell Butte. The Boring Lava at Rocky Butte has been radiometrically dated at 1.3 m.y.b.p. (Edwin McKee and Norman MacLeod, 1985 written communication). 
Pleistocene sediments were deposited onto an uneven, eroded Troutdale Formation surface. The oldest Pleistocene sediment is the apron-like deposit of Cascadian gravels and mudflows of the Springwater Formation and Walters Hill Formations (Trimble, 1963). These rocks were previously included in the Troutdale Formation (Treasher, 1942) because of their similarity to the uppermost Troutdale Formation and deep weathered horizon.

During the remainder of the Pleistocene, the Troutdale Formation and Sandy River Mudstone continued to be eroded in the Portland area and several episodes of sediment deposition and removal took place (Trimble, 1963). 


\section{SUMMARY AND CONCLUSIONS}

Hyaloclastic sediments that characterize the Troutdale Formation are present in wells drilled for the Portland Water Bureau in the Portland basin. Four separate hyaloclastic units were identified in the well area based primarily on stratigraphic position, along with geochemical composition and lithology. The bulk of the hyaloclastic material is contained in the three upper hyaloclastic units (the RC, TSA and UTSA). These three hyaloclastic units form a geochenical and lithologic group that is correlative with both the informal upper member Troutdale Formation of Tolan and Beeson (1984) in the Bridal Veil channel and the type area of the Troutdale Formation along the Sandy River. The well area RC and TSA are distingiushed by beds rich in unweathered plagioclase and olivine-bearing sideromelane grains. The TSA and RC units contain most of the hyaloclastic debris deposited in the well area. The UTSA is the uppermost hyaloclastic debrisbearing unit. It is found in the western and southernmost portion of the well area. The UTSA is generally beds of orange-brown to grayish cemented palagonite. The fourth hyaloclastic unit (LRC) is a hyaloclsatic debris-bearing sandy gravel within well area sediment equivalent to the Sandy River Mudstone and lower Troutdale Formation. The LRC is geochemically as well as stratigraphically distinct from the upper Troutdale Formation hyaloclastic beds. Hyaloclastic units, defined as a diagnostic component of Tolan 
and Beeson's (1984) upper member of the Troutdale Formation can be used as a stratigraphic marker within the Troutdale Formation of the lower Columbia River Gorge and the up to 1700 feet of upper Miocene and Pliocene sediments in the Portland basin. This interval is 300 to 400 feet thick in the well area and up to 500 feet thick in the Bridal Veil channel. The lower Troutdale Formation to upper Troutdale Formation transition within the well area is the base of the RC-TSA-UTSA hyaloclastic debris-bearing sediment.

The hyaloclastic beds probably formed susequent to the confluence of high-alumina basalt lavas with an ancestral Columbia River. Hyaloclastic debris formed during the interaction of lava flows and river water. This clastic debris and fragments of lava were washed downstream and deposited in the Bridal Veil canyon and the Portland basin. The upper Troutdale Formation hyaloclastite units (the UTSA, TSA and RC) are derived from Pliocene high-alumina basalt lavas erupted in the Cascade Range of northern Oregon and/or southern Washington. The LRC glass clasts from the lower member are similar geochemically to the Simcoe Volcanics in southcentral Washington.

According to Trimble (1963) and Tolan and Beeson (1984), much of the non-hyaloclastic sediment of the Troutdale Formation was deposited by an ancestral Columbia River. Modern Columbia River sediments from The Dalles to the Sandy River over-lap sediment samples from the Troutdale Formation and Sandy River Mudstone on a Q-F-L diagram. Trace element geochemistry and petrography show the Troutdale Formation and Sandy River Mudstone sediment to be similar to sediments derived from dissected magmatic arc and continental rocks. Well area sediments 
below the TSA and RC are similar geochemically and petrographically to Sandy River Mudstone and lower member Troutdale Formation. Sediment from within the interval bearing TSA and RC hyaloclastic beds appears to be more lithic-rich than the sediment cuttings below this interval and outcrop samples of Sandy River Mudstone and lower member Troutdale Formation. However, there may be some beds of less lithic Columbia River sediment within the interval that contains the RC, TSA and UTSA. Upper Troutdale Formation hyaloclastites were deposited in a shallow basin, west of the Cascade Range, extending from the Portland area to east of the present-day Sandy River. Hyaloclastic debris was apparently deposited in broad fans or sheets dowstream from the confluence of lava flows by an ancestral Columbia River. The areal extent of this basin is probably similar to the area mapped by Trimble (1963) as Sandy River Mudstone and Troutdale Formation.

The age of formation of the Portland basin is uncertain. Beeson and others (1985) suggested that wrench faulting related to the Portland Hills-Clackamas River Fault Zone, active since mid-Miocene, formed the Portland Basin. The absence of Rhododenron Formation rocks within the well area sediments suggests that they were deposited after Rhododendron Formation volcanism ceased at approximately 10(?) m.y.b.p. The LRC bed, possibly within 200 feet of the base of the post-Columbia River basalt sediment is derived from volcanism which is uppermost Miocene and Pliocene, suggesting that most of the Portland basin sediment is Pliocene in age.

The rhomboidally-shaped Portland Basin, extending eastward from the eastern base of the Tualatin Mountains and encompassing the 
Portland and Vancouver area, was still forming after the deposition of the upper member of the Troutdale Formation. The deformation that resulted in approximately 400 feet of downward displacement between sediments at Prune Hill, Washington and Blue Lake directly across the Columbia River may be tied to Boring Lava volcanism in the Portland area. An age range of $2.6 \mathrm{~m} \cdot \mathrm{y} \cdot \mathrm{b} \cdot \mathrm{p}$. to $1.3 \mathrm{~m} \cdot \mathrm{y} \cdot \mathrm{b} \cdot \mathrm{p}$. has been established from two $\mathrm{K}$-Ar age dates for this period of volcansim. 


\section{REFERENCES CITED}

Allen, J. E., 1932, Contributions to the structure, statigraphy and paleontology of the lower Columbia River Gorge: M. S. thesis (unpublished), University of Oregon, Eugene, Oregon, 96 p. , 1975, Volcanoes of the Portland area, Oregon: Oregon Department of Geology and Mineral Industries, Ore Bin, vol. 38, no. 6, pp. 87-96.

Anderson, J. L., 1978, Structure and stratigraphy of the Columbia River Basalt Group in the Clackamas River Drainage: M. S. thesis (unpublished), Portland State University, Portland, Oregon.

, 1980, Pomona Member of the Columbia River Basalt Group: Oregon Department of Geology and Mineral Industries, Oregon Geology, vol. 42, no. 12, pp. 195-199.

Bahtia, M. H., and Taylor, S. R., 1981, Trace element geochemistry and sedimentary provinces: a study from the Tasman Geosyncline, Australia: Chemical Geology, vol. 33, pp. 115-125.

Barnes, F. F., and Butler, W., 1930, The structure and stratigraphy of the Columbia River Gorge and Cascade Mountains in the vicinity of Mount Hood: M. S. thesis (unpublished), University of Oregon, Eugene, Oregon, $73 \mathrm{p}$.

Beeson, M. H., Fecht, K. R., Reidel, S. P., and Tolan, T. L., 1985, Regional correlations within the Frenchman Springs Member of the Columbia River Basalt Group: New insights into the middle Miocene tectonics of northwestern Oregon: Oregon Department of Geology and Mineral Industries, Oregon Geology, vol. 47, no. 8, pp. 87-96.

Beeson, M. H., Johnson, A. G., and Moran, M. R., 1975, Portland Environmental Geology-Fault Identification: final technical report, U. S. Geological Survey contract no. 14-08-0001-14832, Geology Department, Portland State University, Portland, Oregon.

Beeson, M. H., and Moran, M. R., 1979, Stratigraphy and structure of the Columbia River Basalt Group in the Cascade Range, Oregon, in Hu11, D. A., investigator, and Riccio, J. F., ed., Geothermal Resource Assesment of Mount Hood, Oregon Department of Geology and Mineral Industries open file report $0-79-8$, pp. 5-77. 
Beeson, M. H., and Nelson, D. O., 1978, A model for the geologic history of Mount Tabor, Kelly Butte, and Powell Butte in southeast Portland: Proceedings from the Oregon Academy of Science, vol. xiv, pp. 142-143.

Beeson, M. H., Perttu, R, and Perttu, J., 1979, The origin of the basalts of coastal Oregon and Washington: An alternative hypothesis: Oregon Department of Geology and Mineral Industries, Oregon Geology, vol. 41, no. 10, pp. 159-166.

Bretz, J. H., 1917, Satsop Formation of Washington and Oregon: Journal of Geology, vol. 25, pp. 446-458.

Burch, Darolyn, 1980, unpublished M. S.thesis manuscript and geochemical data, Geology Department, Portland State University, Portland, Oregon.

Cole, D. L., 1983, A preliminary investigation of the lithological characteristics of the Troutdale Formation in a portion of Camas, Sandy, Washougal and Bridal Veil Quadrangles: M. S. thesis (unpublished), Portland State University, Portland, Oregon, $69 \mathrm{p}$.

Davis, S., 1986, Gravity study of the Lackamas Lake Lineament: unpublished M. S. thesis manuscript, Portland State University, Portland, Oregon.

Deer, W. A., Howie, R. A., and Zussman, J., 1966, An introduction to the rock-forming minerals: Longman Group Ltd., London, 528p.

Fecht, K. R., Reidel, S. P., and Tallman, A. M., 1983, Paleodrainage of the Columbia River System on the Columbia Plateau of Washington State: A summary: preliminary draft, Basalt Waste Isolation Project RHO-BW-SA-318P, Rockwell International, Richland, Washington, $89 \mathrm{p}$.

Fisher, R. V., and Schmincke, H. U., 1984, Pyroclastic Rocks: Springer-Verlag, Berlin, Germany, 472 p.

Flanagan, F. J., 1976, Descriptions and analyses of eight new U.S.G.S. rock standards: U. S. Geological Survey Professional Paper 840, $192 \mathrm{p}$.

Foxworthy, B. L., Hogenson, G. M., and Hampton, E. R., 1964, Records of wells and springs, water levels, and chemical quality of ground water in the east Portland area, Oregon: State of Oregon Ground Water Report no. 3, 79 p.

Fuller, R. E., 1931, The aqueous chilling of basaltic lava on the Columbia River Plateau: American Journal of Science, fifth ser., vol. 21 , no. 124, pp.281-300. 
Furnes, H., 1978, Elemental mobility during palagonitization of a surficial hyaloclasite in Iceland: Chemical Geology, vol. 22, pp. 249-264.

Gannett, M., 1982, A geochemical study of the Rhododendron and The Dalles Formations in the area of Mount Hood, Oregon: M. S. thesis (unpulished), Portland State University, Portland, Oregon, $70 \mathrm{p}$.

Goff, F. E., 1977, Vesicle cylinders in vapor-differentiated basalts flows: Ph.D. dissertation (unpublished), University of California, Santa Cruz, 181 p.

Hammond, P. E., 1979, A tectonic model for the evolution of the Cascade Range, in Armentrout, J. M., Cole, M. R., and Terbest, H. R. Jr., eds., Cenozoic Paleogeography of the Western United States: Pacific section, Society of Economic Paleontologists and Mineralogists, pp. 219-237.

, 1980, Reconnaissance geologic map and cross-sections of the Southern Washington Cascade Range, latitude 45 30'-47 $15^{\prime} \mathrm{N}$, longitude $120 \quad 45^{\prime}-122$ 22.5' W: Department of Geology, Portland State University, Portland, Oregon, 2 sheets, 1:125,000, $31 \mathrm{p}$.

Hammond, P. E., and Korosec, M. A., 1983, Geochemical analyses, age dates, and flow-volume estimates for Quaternary volcanic rocks, southern Cascade Mountains, Washington: Washington Division of Geology and Natural Resources Open File Report 83-13, 36 p.

Haskin, L. A., Wildeman, T. R., Frey, F. A., Collins, K. A., Keedy, C. R., and Haskin, M. A., 1966, Rare earths in sediments: Journa1 of Geophysical Research, vo1. 71, pp. 6091-6105.

Hay, R. L., and Iijima, A., 1968, Nature and origin of palagonite tuffs of the Honolulu Group on Oahu: Geological Society of America Memior 116, pp. 331-376.

Hodge, E.T., 1938, Geology of the lower Columbia River: Geological Society of America Bulletin, vol. 49, no. 6, pp. 831-930.

Hoffstetter, W. H., 1984, Geology of the Portland Well Field: Oregon Department of Geology and Mineral Industries, Oregon Geology, vo1. 46, no. 6, pp. 63-67.

Huntting, M. T., Bennet, W. A. G., Livingston, V. E. Jr, and Moen, W. S., 1961, Geologic map of Washington: Washington Department of Natura1 Resources Geologic Map, 2 sheets, 1:500,000.

Kadri, M. M., 1982, Structure and influence of the Tillamook uplift on the stratigraphy of the Mist area, Oregon: M. S. thesis (unpublished), Portland State University, Portland, Oregon, 105p. 
Lowry, W. D., and Baldwin, E. M., 1952, Late Cenozoic geology of the lower Columbia River Valley, Oregon: Geological Society of America Bulletin, vol. 63, no. 1, pp. 1-24.

McBirney, A. R., and White, C. M., 1982, The Cascade Province: in Thorp, R. S. ed., Orogenic Andesites and Related Rocks, John Wiley and Sons, pp. 115-135.

McBride, E. F., 1963, A classification of the common sandstones: Journal of Sedimentary Petrology, vol. 33, pp. 664-669.

McLennan, S. M., Nance, W. B., and Taylor, S. R., 1980, Rare earth element-thorium content in sedimentary rocks and the composition of the continental crust: Geochimica et Cosmochimica Acta, vol. 44, pp. 1833-1839.

Miyashiro, A., 1974, Volcanic rock series in island arcs and active continental margins: American Journal of Science, vol. 274, pp. 321-355.

Mundorff, M. J., 1964, Geology and ground water conditions of Clark County, Washington, with a description of a major alluvial aquifer along the Columbia River: U. S. Geological Survey Water Supply Paper 1600, 268 p.

Nance, W. B. and Taylor, S. R., 1976, Rare earth element patterns and crustal evolution: I. Australian post-Archean sedimentary rocks: Geochimica et Cosmochimica Acta, vol. 40, pp. 1539-1551.

Newton, V. C. Jr., 1969, Subsurface geology of the lower Columbia and Willamette Basins, Oregon: Oregon Department of Geology and Mineral Industries 0il and Gas Investigation, no. 2, $121 \mathrm{p}$.

Peck, D. L., Griggs, A.B., Schlicker, H. G., Wells, F. G., and Dole, H. M., 1964, Geology of the central and northern part of the Western Cascade Range in Oregon: U.S. Geological Survey Professional Paper 449, 56 p.

Priest, G. R., 1982, Overview of the geology and geothermal resources of the Mount Hood area, Oregon, in Priest, G. R., and Vogt, B. F., eds., Geology and Geothermal Resources of the Mount Hood Area, Oregon, Oregon Department of Geology and Mineral Industries Special Paper 14, pp. 6-15.

Priest, G. R., Beeson, M. H., Gannet, M. W., and Berri, D. A., 1982, Geology, geochemistry and geothermal resources of the Old Maid Flat area, Oregon, in Priest, G. R., and Vogt, B. F., eds., Geology and Geothermal Resources of the Mount Hood Area, Oregon, Oregon Department of Geology and Mineral Industries Special Paper 14, pp. 16-30. 
Priest, G. R., Woller, N. M., Black, G. L., and Evans, S. H., 1983, Overview of the geology of the Central Oregon Cascade Range, in Priest, G. R., and Vogt, B. F., eds., Geology and geothermal resources of the Central Oregon Cascade Range, Oregon Dept. of Geology and Mineral Industries Special Paper 15, pp. 3-28.

Silvestri, S. C., 1961, Proposal for the genetic classification of hyaloclastites: Bulletin Volcanologique, vol. 25, pp. 315-321.

Swanson, D. A., Wright, T. L., Hooper, P. R., and Bentley, R. D., 1979, Revisions in stratigraphic nomenclature of the Columbia River Basalt Group: U.S. Geological Survey Bulletin 1457-G, $59 \mathrm{p}$.

Tolan, T. L., 1982, The stratigraphic relationships of the Columbia River Basalt Group in the lower Columbia River Gorge of Oregon and Washington: M. S. thesis (unpublished), Portand State University, Portland, Oregon, $151 \mathrm{p}$.

Tolan, T. L., and Beeson, M. H., 1984, Intracanyon flows of the Columbia River Basalt Group in the lower Columbia River Gorge and their relationship to the Troutdale Formation: Geological Society of America Bulletin, vol. 95, no. 4, pp. 463-477.

Treasher, R. C., 1942, Geologic history of the Portland area: Oregon Department of Geology and Minera1 Industies Short Paper 7, 17 p.

Trimble, D. E., 1957, Geology of the Portland quadrangle, Oregon and Washington: U. S. Geological Survey Quadrangle Map GQ-104.

, 1963, Geology of Portland, Oregon and adjacent areas: U.S. Geological Survey Bulletin $1119,119 \mathrm{p}$.

Van Atta, R. O., and Kelty, K. B., 1985, Scappoose Formation, Columbia County, Oregon: New evidence of age and relation to the Columbia River Basalt Group: American Association of Petroleum Geologists Bulletin, vol. 69, pp. 688-698.

Waters, A. C. 1973, The Columbia River Gorge: basalt stratigraphy, ancient lava dams, and landslide dams, in Beaulieu, J. D., field trip chairman, 1973, Geolgic field trips in northern Oregon and southern Washington: Oregon Department of Geology and Minera1 Industries Bulletin 77, pp. 133-162.

Wells, F. G., and Peck, D. L., 1961, Geologic map of Oregon west of the 121 st meridian: U. S. Geological Survey Miscellaneous Investigations Map I-325, 1:500,000, 2 sheets.

Whetten, J. T., Ke11y, J. C., and Hanson, L. G., 1969, Characteristics of Columbia River sediment and sediment transfort: Journal of Sedimentary Petrology, vol. 39, no. 3, pp. 1149-1166. 
White, C. M., and McBirney, A. R., 1978, Some quantitative aspects of orogenic volcanism in the Oregon Cascades, in Smith, R. B., and Eaton, G. P., eds., Geological Society of America Memior 152, pp. 369-388.

Williams, I. A., 1916, The Columbia River Gorge: Its geologic history interpreted from the Columbia River Highway, Oregcn: Bureau of Mines and Geological Mineral Resources of Oregon, vol. 2, no. 3, $130 \mathrm{p}$.

Willis, R. F., 1977, Ground-water exploratory program, Bureau of Waterworks, Portland, Oregon: unpulished Portland Water Bureau report, $150 \mathrm{p}$.

Wise, W. S., 1969, Geology and petrology of the Mount Hood area: A study of High Cascade volcarism: Geological Society of America Bulletin, vol. 80, pp.696-1006. 
APPENDIX A

SAMPLE TYPE, UNIT AND LOCATION

INAA Experiment $7 \mathrm{~T}$

Sample Rock Type Unit Location

5-135 sed $s$ Ttu Well 1N/3E 20CB2

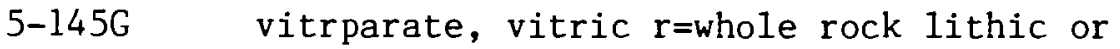

vitric sediment.

Unit Symbols: QTb=Boring Lava, Tb="upper Pliocene" basalt of the High Cascade Lavas, Ttu=upper Troutdale Formation, Ttl=lower Troutdale Formation, Tsr=Sandy River Mudstone.sed s " Ttu

\begin{tabular}{|c|c|c|c|}
\hline $5-440$ & sed $s$ & Ttu & 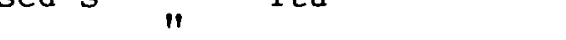 \\
\hline $5-535$ & sed $s$ & Ttu & $"$ \\
\hline $5-585$ & sed $s$ & Tt 1 & $"$ \\
\hline $5-670$ & sed $s$ & $\mathrm{Tt} 1$ & $"$ \\
\hline $5-710$ & sed $s$ & Tt1 & $"$ \\
\hline $5-795$ & sed $s$ & $\mathrm{Tt} 1$ & $"$ \\
\hline $5-970$ & sed $s$ & $\mathrm{Tt} I$ & " \\
\hline $5-1100$ & sed $s$ & $\mathrm{Tt} 1$ & " \\
\hline LSWSSB & vitric $r$ & Ttu & T1S, R4E, Sec 6, NW,SE \\
\hline $1160 P M R$ & vitric $\mathrm{r}$ & Ttu & T1N, R5E, Sec 27, NE, SE, NE \\
\hline SLTSSB & vitric $r$ & Ttu & T1S, R4E, Sec 6, NE, SW, NW \\
\hline CHPT & Vitric $r$ & Ttu & T1N, R4E, Sec 25, SW \\
\hline 700PMR & sed $w$ & Ttl & T1N, R5E, Sec 22, SE,SW, NW \\
\hline SRMGC & sed $w$ & Tsr & T1S, R4E, Sec 11, SE, NW, SE \\
\hline
\end{tabular}

INAA Experiment $\underline{7 \mathrm{H}}$

\begin{tabular}{|c|c|c|c|}
\hline Sample & Rock Type & Unit & Location \\
\hline $2-780$ & sed $\mathbf{s}$ & $\mathrm{Ttl}$ & Well $1 \mathrm{~N} / 3 \mathrm{E}$ 31CD \\
\hline $2-800$ & sed $s$ & $\mathrm{Tt} 1$ & " \\
\hline $2-820$ & sed $s$ & $\mathrm{Tt} 1$ & $"$ \\
\hline $2-850$ & sed $s$ & $\mathrm{Ttl}$ & $"$ \\
\hline $2-870$ & sed $s$ & $\mathrm{Tt} 1$ & $"$ \\
\hline $2-895$ & sed $s$ & $\mathrm{Tt} 1$ & $"$ \\
\hline $2-925$ & sed $s$ & Tt1 & $"$ \\
\hline $2-945$ & sed $s$ & $\mathrm{Tt} 1$ & $"$ \\
\hline $2-975$ & sed $s$ & $\mathrm{Ttl}$ & $"$ \\
\hline $2-1000$ & sed $s$ & $\mathrm{Tt} 1$ & $"$ \\
\hline $1-890$ & sed $s$ & $\mathrm{Tt} 1 / \mathrm{Ttu}$ & Well $1 \mathrm{~N} / 2 \mathrm{E}$ 29DA \\
\hline $1-935$ & sed $\mathbf{s}$ & Tt1 & \\
\hline
\end{tabular}


INAA Experiment $7 \mathrm{H}$ (continued)

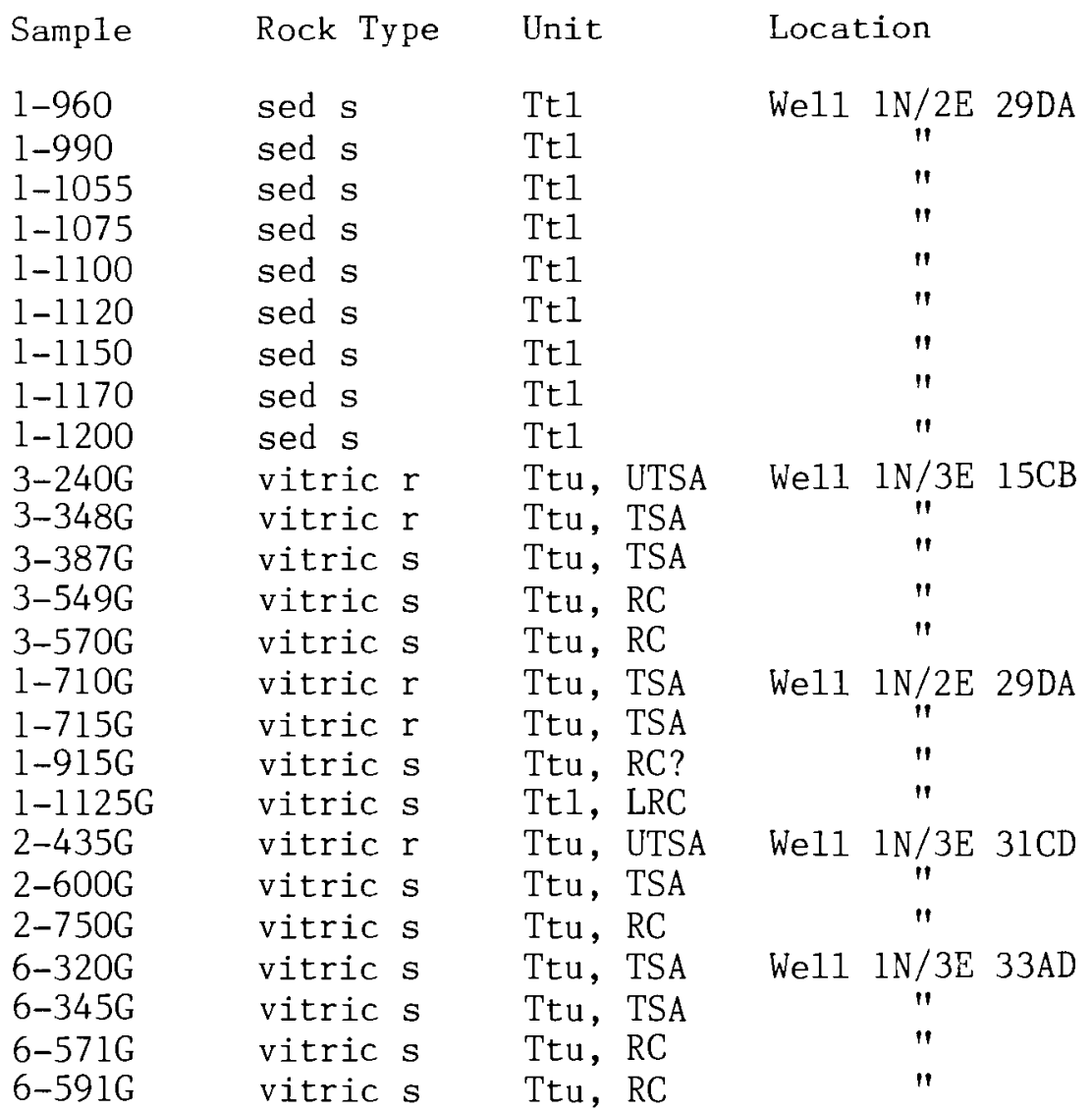

INNA Experiment 7K

\begin{tabular}{|c|c|c|c|}
\hline Sample & Rock Type & Unit & Location \\
\hline $\mathrm{HR}-1 \mathrm{~B}$ & basalt & $\mathrm{Tb}$ & $\begin{array}{l}\text { T3N, R10E, Sec 33, NW, NW, NW; West } \\
\text { Hood River palagonite complex }\end{array}$ \\
\hline $\mathrm{HR}-3 \mathrm{~B}$ & basalt & $\mathrm{Tb}$ & T3N, R10E, Sec 33, NW, NW, NE \\
\hline $\mathrm{HR}-3 \mathrm{G}$ & bas/glass & $\mathrm{Tb}$ & T3N, R10E, Sec 33, NW, NW, NE \\
\hline HR-MHB & basalt & $\mathrm{Tb}$ & T3N, R10E, Sec 33, NW, NW \\
\hline $\mathrm{HR}-5 \mathrm{~B}$ & basalt & $\mathrm{Tb}$ & $\begin{array}{l}\text { T3N, R1OE, Sec } 33, \mathrm{NE}, \mathrm{NW}, \mathrm{NW} \text {; } \\
\text { Basalt flow at West Hood River } \\
\text { interchange }\end{array}$ \\
\hline $\mathrm{HR}-11 \mathrm{~B}$ & basalt & $\mathrm{Tb}$ & $\begin{array}{l}\text { T2N, R1OE, Sec 1, SE, NE, NW; Basa1t } \\
\text { of Panorama Point }\end{array}$ \\
\hline $\mathrm{HR}-12 \mathrm{~B}$ & basalt & $\mathrm{Tb}$ & T2N, R1OE, Sec 26, SE,SW,SW \\
\hline WA-2B & basalt & QTb & T1N, R3E, Sec 7, NE, SW, Prune Hi11 \\
\hline$B V-6 B$ & basalt & $\mathrm{Tb}$ & $\begin{array}{l}\text { T1N, R5E, Sec 27, NE, NE, NE; Bridal } \\
\text { Veil section }\end{array}$ \\
\hline WR-1GL & vitric r & Ttu, TSA & $\begin{array}{l}\text { T2S, R4E, Sec 5, NW, NW, NW, NE; } \\
\text { Woodard Rd. section }\end{array}$ \\
\hline WR-5G & vitric s & Ttu, TSA & T2S, R4E, Sec 5, NW, NW, NE, NE \\
\hline
\end{tabular}


$\underline{\text { INAA Experiment }} \underline{7 \mathrm{~K}}$ (continued)

\begin{tabular}{|c|c|c|c|}
\hline Sample & Rock Type & Unit & Location \\
\hline WR-8G & vitric s & Ttu, TSA & T2S, R4E, Sec 5, NW, NE, NW, NE \\
\hline $\mathrm{BV}-7 \mathrm{G}$ & vitric s & Ttu, TSA? & $\begin{array}{l}\text { T1N, R5E, Sec } 22 \text {, SE, SW, SE, NE } \\
\text { Bridal Veil section }\end{array}$ \\
\hline $\begin{array}{l}\text { BV-2G } \\
\text { BV-9G }\end{array}$ & vitric s & Ttu, TSA & T1N, R5E, Sec 22, SE, SW, SE, NE \\
\hline GCR-4G & vitric s & Ttu, TSA & $\begin{array}{l}\text { TIS, R4E, Sec 11, NW, SE, NW, SE } \\
\text { Gordon Creek Rd. section }\end{array}$ \\
\hline TB-3G & vitric s & Ttu, TSA & $\begin{array}{l}\text { T1N, R3E, Sec } 20, \mathrm{NE}, \mathrm{SW}, \mathrm{NE} \\
\text { Taggart Bluff, } 1 / 3 \text { mile NE of } \\
\text { Blue Lake }\end{array}$ \\
\hline $\mathrm{BL}-2 \mathrm{G}$ & vitric s & Ttu, TSA & $\begin{array}{l}\text { TIN, R3E, Sec } 20, \text { SE, NE, NW West } \\
\text { end of Blue Lake }\end{array}$ \\
\hline P28-375G & vitric $s$ & Ttu, TSA & Production well P28 \\
\hline T34-390G & vitric $s$ & Ttu, TSA & Test we11 T34 \\
\hline GCR-2F & sed $s$ & Tsr & TIS, R4E, Sec NW, SE, SE, NE \\
\hline GCR-2C & sed $w$ & Tsr & T1S, R4E, Sec NW,SE,SE, NE \\
\hline
\end{tabular}

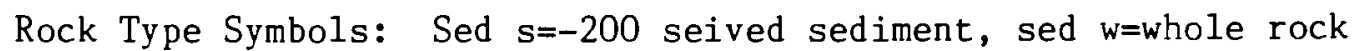
sediment, vitric s=vitric separate, vitric $r=$ whole rock lithic or vitric sediment.

Unit Symbols: QTb=Boring Lava, Tb="upper Pliocene" basalt of the High Cascade Lavas, Ttu=upper Troutdale Formation, Ttl=lower Troutdale Formation, Tsr=Sandy River Mudstone. 
APPENDIX B

\section{GEOCHEMICAL ANALYTICAL PROCEDURE AND ELEMENTAL CONCENTRATION TABLES}

Samples were analyzed in three experiments. Experiment $7 \mathrm{~T}$ was conducted in spring 1983 as part of a required project for Advanced Geochemistry (G519). Steve Davis and Matt McClincey assisted in the experiment. Twenty-two samples were analyzed: Thirteen sediment and three hyaloclastite separates from Exploratory Well 1N/3E 20CB2 (number 5) along with six sediment samples collected from outcrops of the Troutdale Formation and Sandy River Mudstone. Thirty-seven well cutting samples were analyzed in experiment $7 \mathrm{H}$ in fall 1984. Twentyone were sediment samples and sixteen were hyaloclastite separates. Wells sampled included 1N/2E 29DA (number 1), 1N/3E $31 \mathrm{CD}$ (number 2), $1 \mathrm{~N} / 2 \mathrm{E} 15 \mathrm{CB}$ (number 3) and $1 \mathrm{~N} / 3 \mathrm{E} 33 \mathrm{AD}$ (number 6). Sample numbers for well samples in experiments $7 \mathrm{~T}$ and $7 \mathrm{H}$ correspond to well number $(1,2$, 3, 5, or 6) and sample depth from ground level in feet. Experiment $7 \mathrm{~K}$ was performed in spring 1985. The twenty-eight samples analyzed were primarily field samples with a few well samples. A description of samples and their location can be found in Appendix A.

Well sediment was wet seived to -200 mesh and dried in porcelain dishes. Hyaloclastite glass separates were picked from cuttings or hand sample using a jewelers tweezers under a binocular microscope. Three to six grams of vitic clasts per sample were obtained by selecting grains lacking weathering rinds or cemented fine grained 
sediment attached. All vitric separates were washed in a solution of calgonite and water in an ultrasonic cleaner and rinsed with tap water. Whole sediment samples in experiments $7 \mathrm{~T}$ and $7 \mathrm{~K}$ were easily disaggregated for splitting and weighing. Basalt samples analyzed in experiment $7 \mathrm{~K}$ were crushed in a steel jaw crusher. Clean unweathered chips were then selected for analysis.

Samples were crushed in a hardened steel mortar and pestal used only for INAA sample preparation. Samples were split down to about one gram by halving a pile poured onto two weighing papers. Each sample was then placed in a pre-weighed polyethelene vial for irradiation. Sample and vial were then weighed to tor- .0002 grams to obtain the net sample weight.

Standards BCR-1 and $W-1$ were used in experiment 7T. Standards BCR-1 and PCC-1 were used in experiments $7 \mathrm{H}$ and $7 \mathrm{~K}$. Values for element concentrations in the standards were taken from Flanagan (1976). Samples and standards were irradiated for one hour in Reed College's TRIGA Mark II reactor. Irradiation produces unstable radionuclides by neutron bombardment. One of the products of decay of these unstable isotopes is gamma radiation. Each isotope has a characteristic energy spectrum when counted on a Ge-Li detector which in this case is connected to Tracor Northern hardware and software. Each sample, when counted, produces a spectum consisting of peaks that represent individual radioisotopes. Peak intensities are relative to the concentration of radionuclides in the sample.

The Tracor Northern software analyzes each samples spectrum to determine the net count of each peak and the counting error as a 
percentage by comparing the peak's shape to an ideal bell-shaped curve. Elemental concentrations are determined for each sample by a program in the Portland State University's main frame Honeywell computer. The program compares net counts and percent error of peaks along with weight and decay time for each sample to those of the standards to calculate elemental concentrations and one standard deviation. 


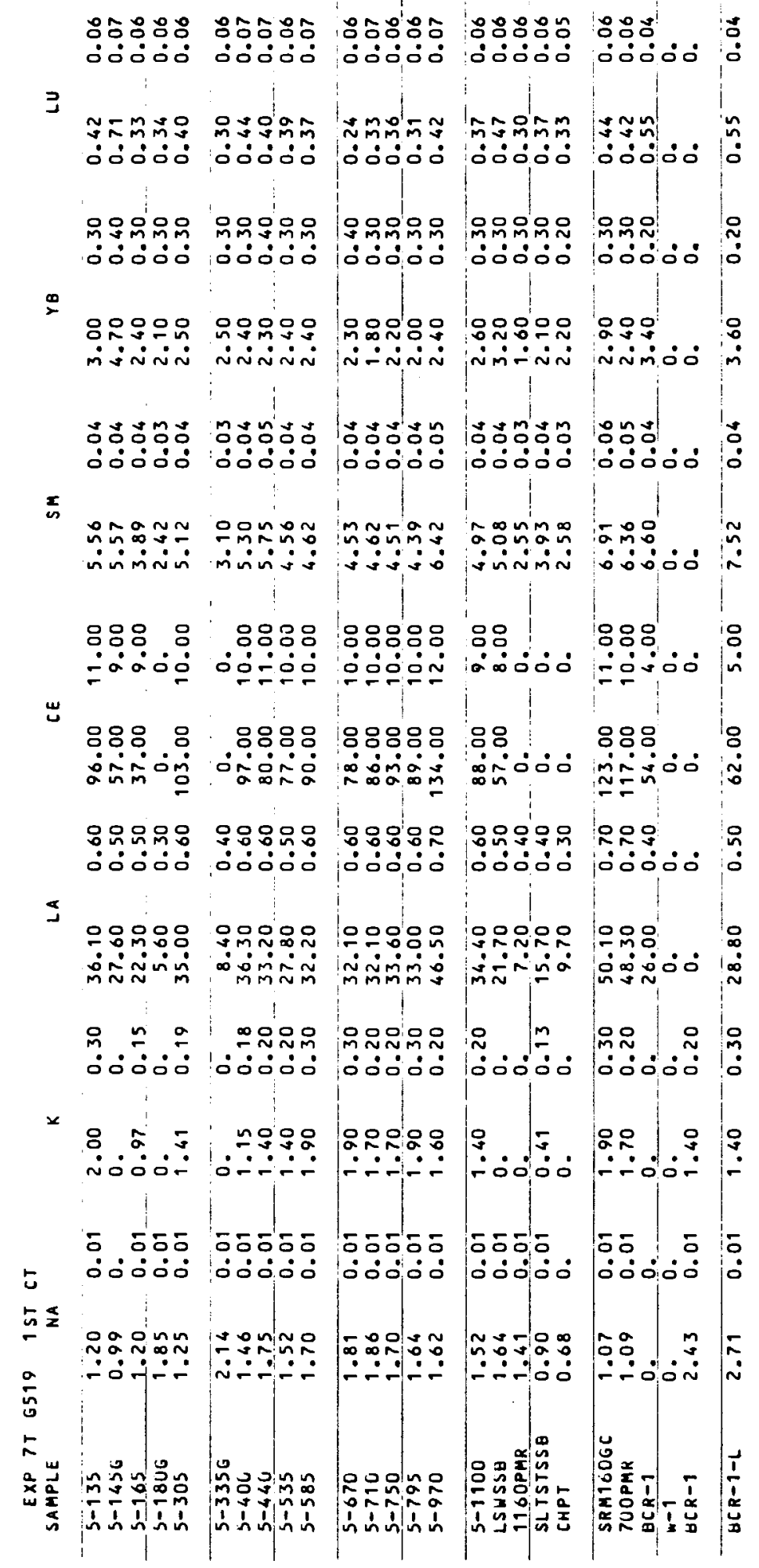




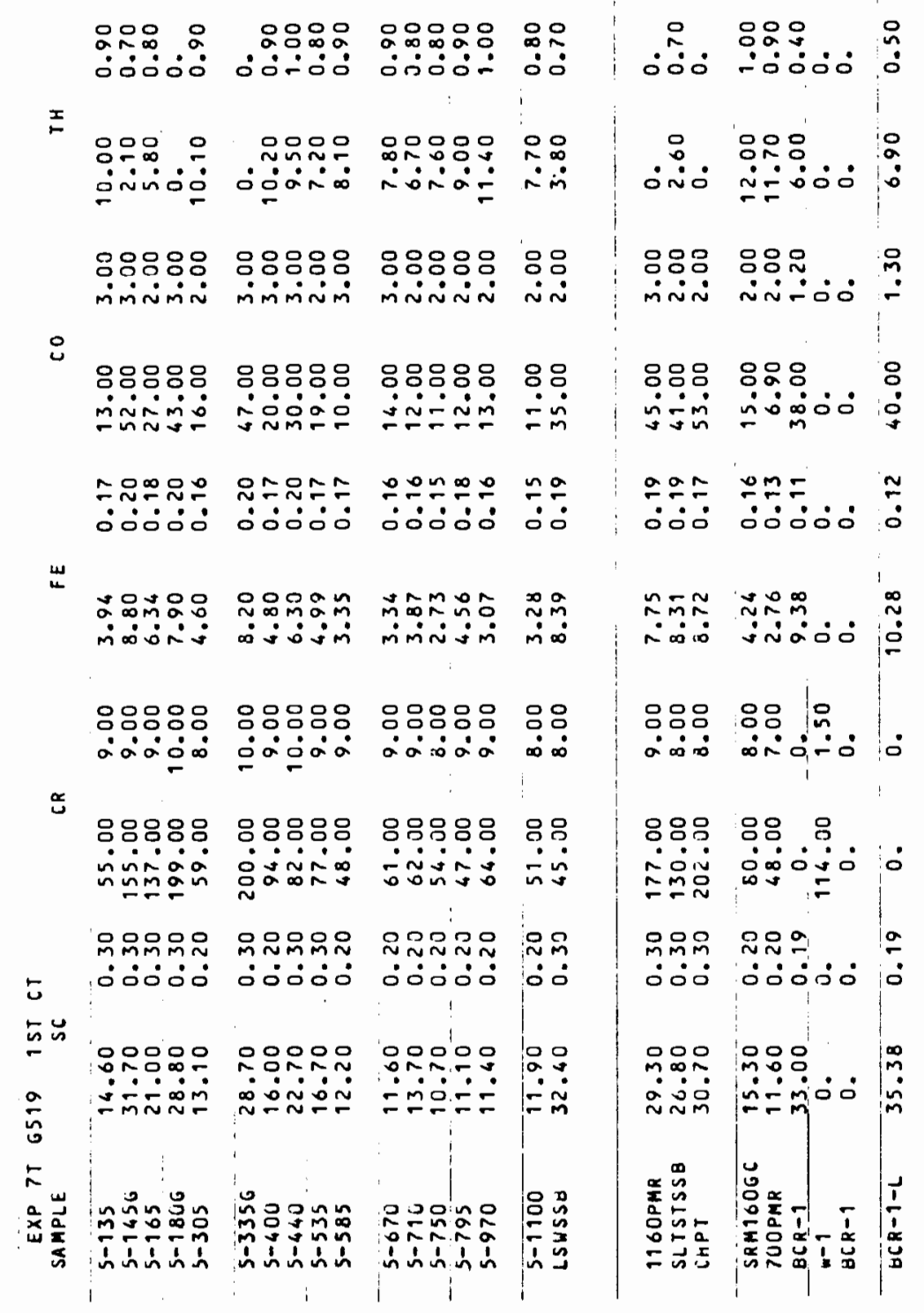




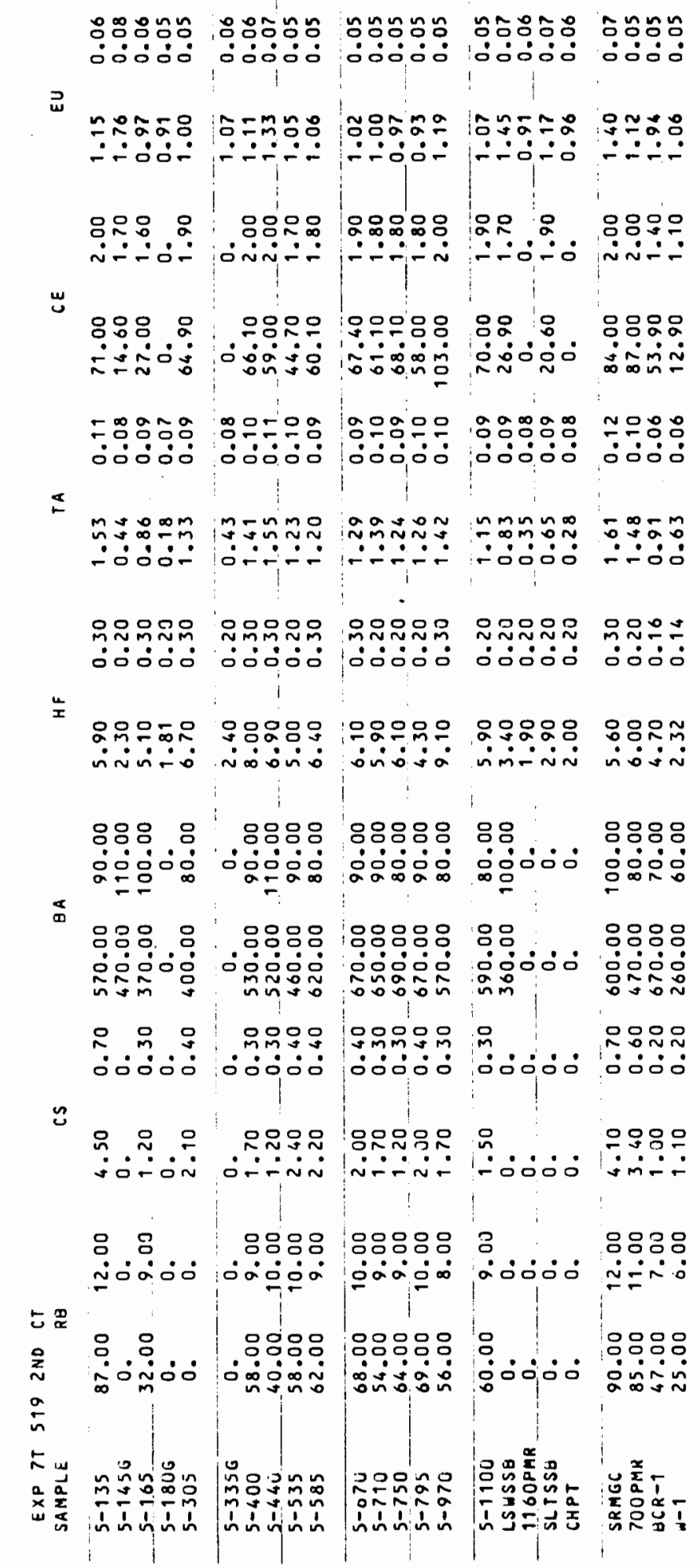




\begin{tabular}{|c|c|c|c|c|c|}
\hline & 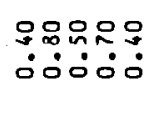 & 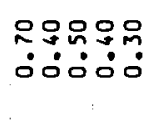 & 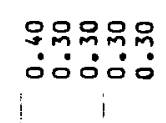 & 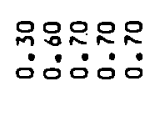 & 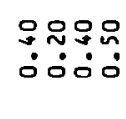 \\
\hline 8 & 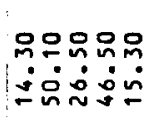 & 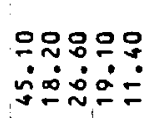 & 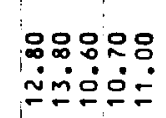 & 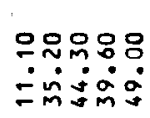 & 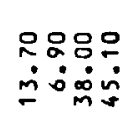 \\
\hline & 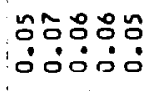 & 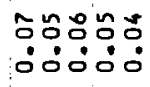 & 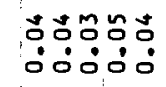 & 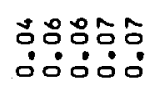 & 茴 \\
\hline$u$ & 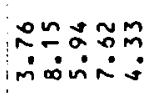 & 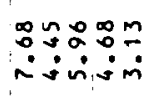 & 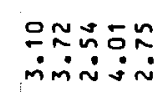 & 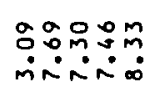 & 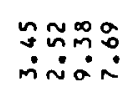 \\
\hline & 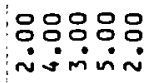 & 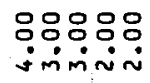 & نَ & 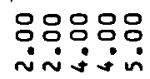 & 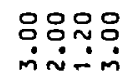 \\
\hline u & 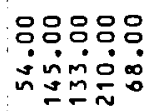 & 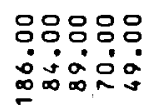 & 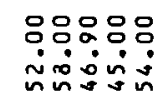 & 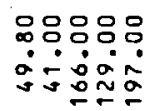 & 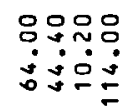 \\
\hline & 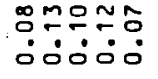 & 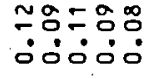 & 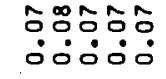 & 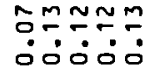 & 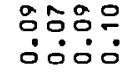 \\
\hline s & 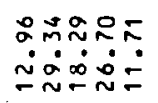 & 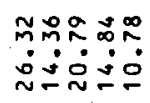 & 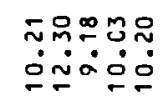 & 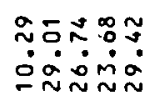 & 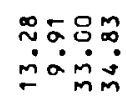 \\
\hline & 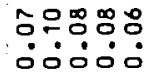 & 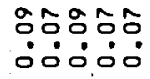 & 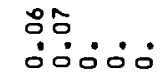 & 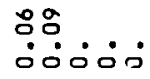 & 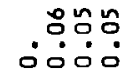 \\
\hline 3 & 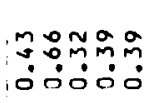 & 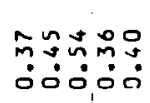 & 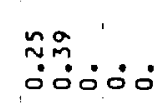 & 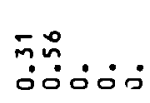 & 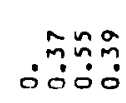 \\
\hline & $\begin{array}{l}0 \\
0\end{array}$ & 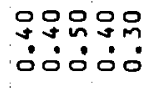 & 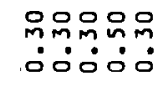 & 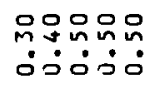 & 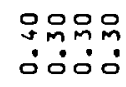 \\
\hline 2 & 울뭄ำ & 预品: & 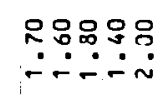 & 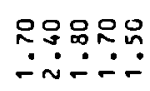 & 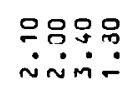 \\
\hline & 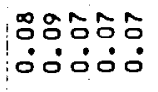 & 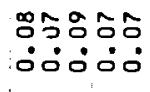 & 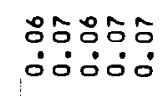 & مُ & 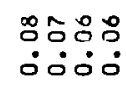 \\
\hline ¿ & 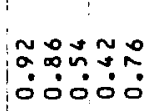 & 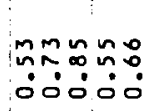 & 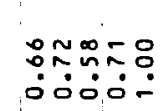 & 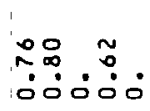 & 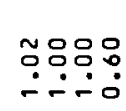 \\
\hline 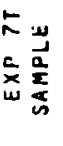 & 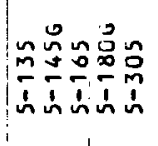 & 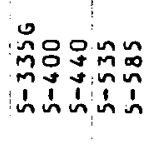 & 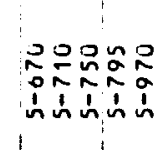 & 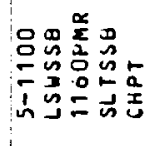 & \\
\hline
\end{tabular}




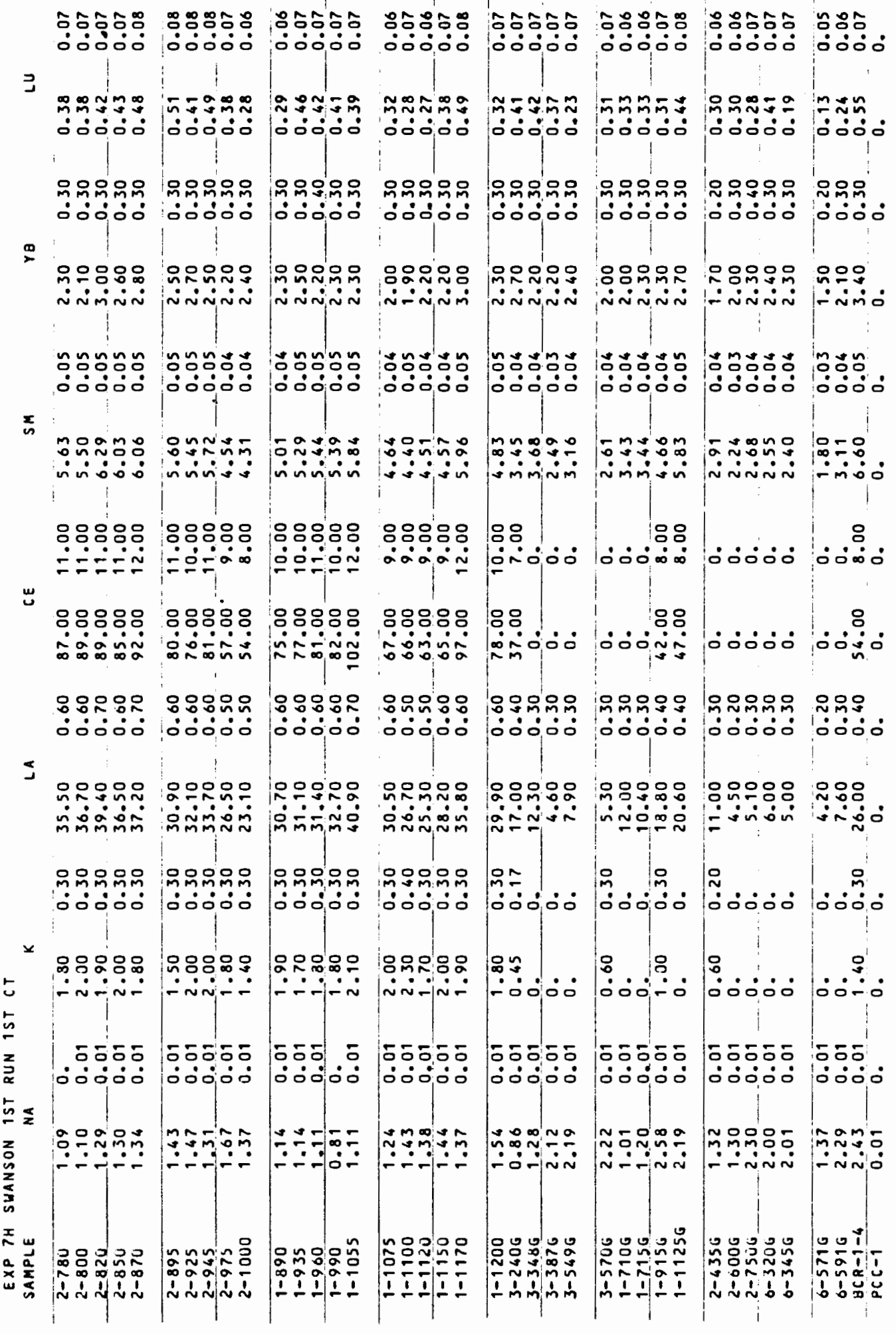




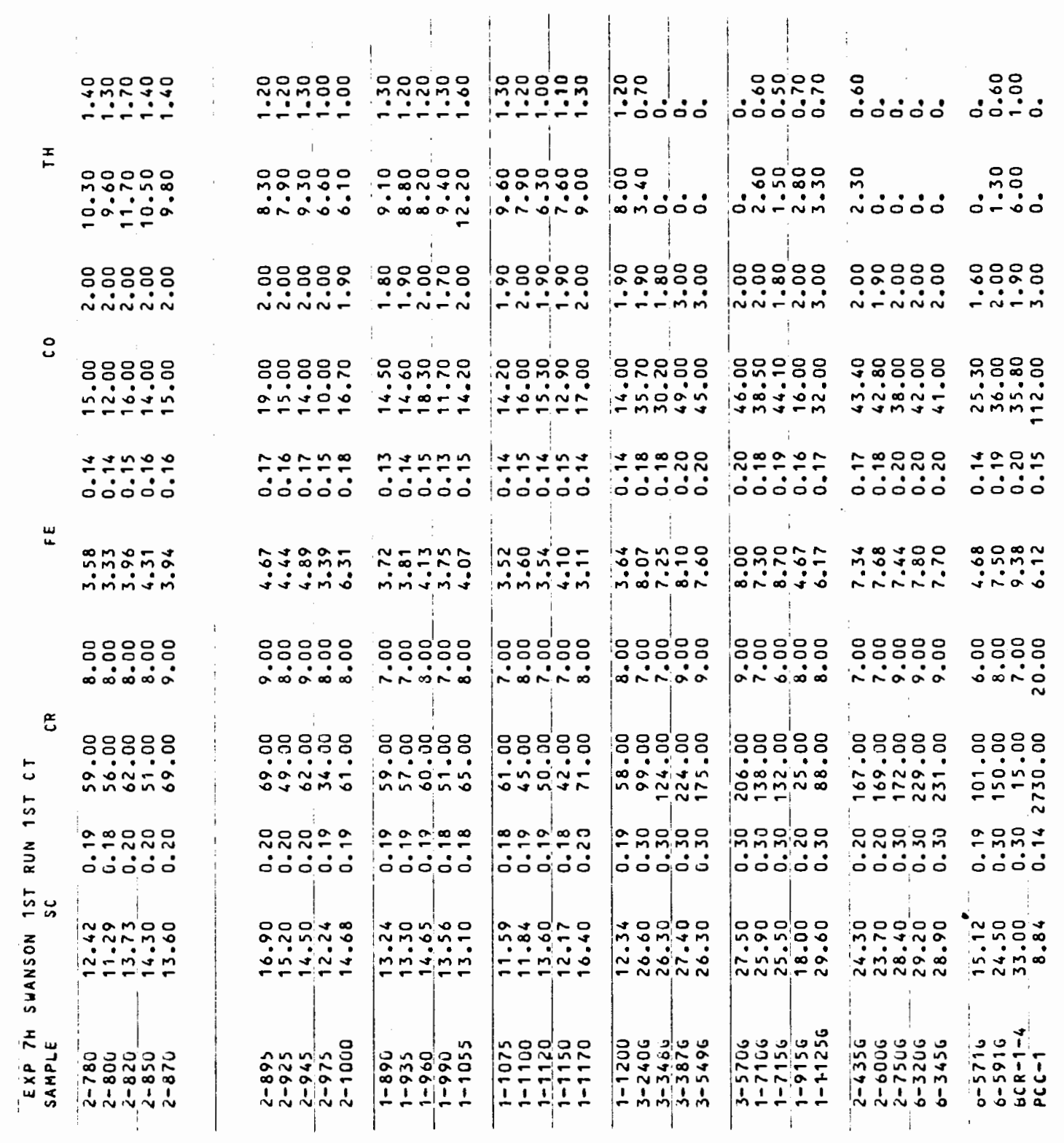


ய

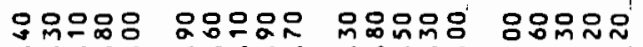

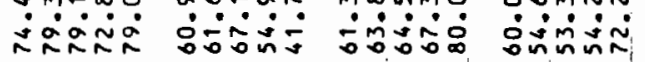

옹으으으 오응ํㅇ ㅇํㅇ영=

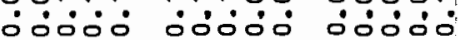

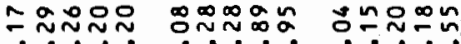
$\because \because \because \because \because \dot{0} \because \because \because$

00000 00000 natomo

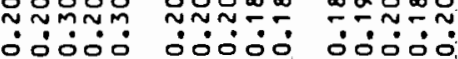

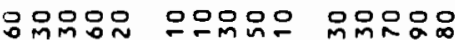

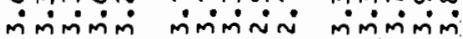

응응ㅇㅁㅇㅇㅇㅇㅇㅇ

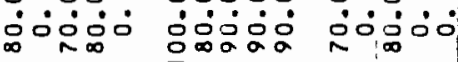

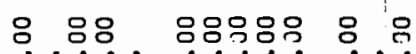
வ்ட0்

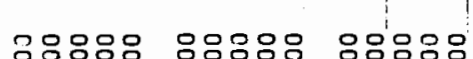

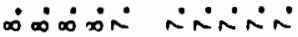
ninisió

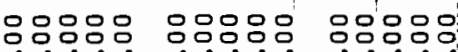

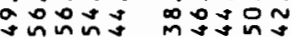

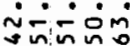

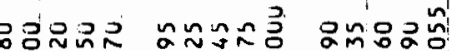

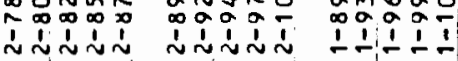

ㅇํㅇㅇำ வ000.

ลำกัะ 무:-

$\simeq \infty \sim \infty 0$

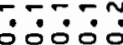
วัธธ์ㅇํㅇ minimini

৪88요 i뭄ㅁㅇ 옹ㅇㅇㅇㅇㅁ ட்ंi்:

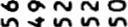

옹응용 ¿ன்ْं

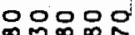
mininim

옹옹용 뭉ㅇㅇ 응요음

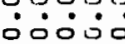

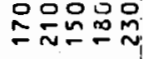
응응응 $\dot{\infty} \dot{\infty} \dot{\infty} \dot{n}$

옹용ㅇㅁㅇ

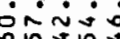
IIIII

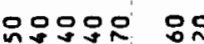

용ㅇㅇㅇㅇ

8

$\div \mathbb{N}^{\circ}$

ํํำล ธ่อ门o.

जिंत्र

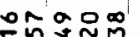
-ீं0்

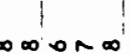

åjó

$\stackrel{\infty}{\sim}=\infty$

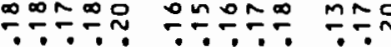
óóo óojó jojo

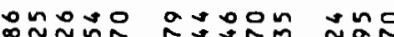
- inimin $\because \because \therefore \because \therefore 0$

움우 응

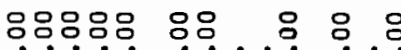
뭉요 용ㅇㅁ

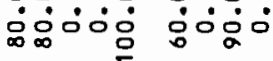
용 용ㅁㅇ 88808

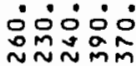
응ㅇㅇㅇㅛ ñ

유유

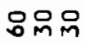

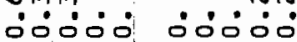
ㅁㅇㅇㅛ

으웅ㅇㅁ

웅 mं०-ं0 வீं்:

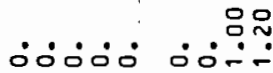

응

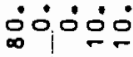

응 웅응 응음응 응 응

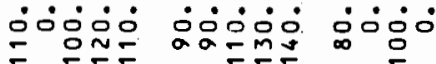

8 88: i

응요용

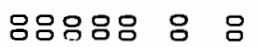

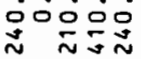

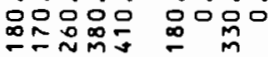

88 응 용 용요

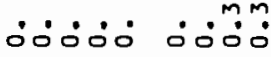
ainos

용ㅇㅇ

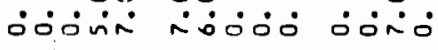
용 in

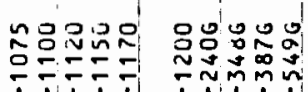

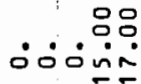
玄்

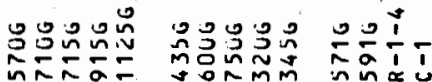

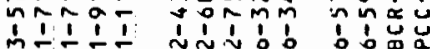




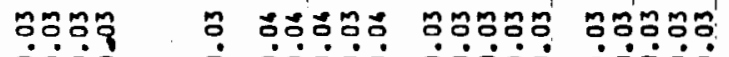

w

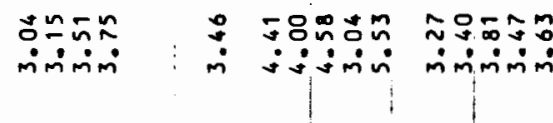

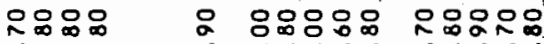

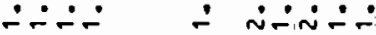

$\stackrel{\infty}{u}$

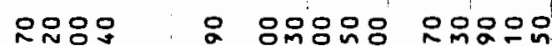

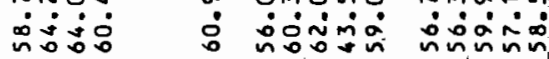

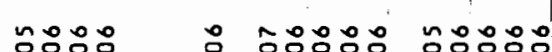

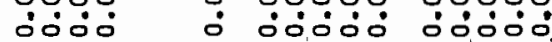

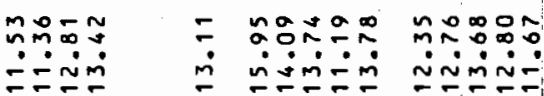

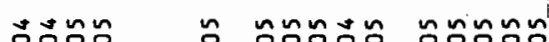

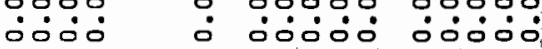

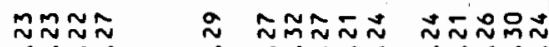

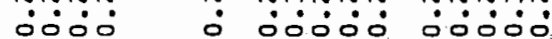

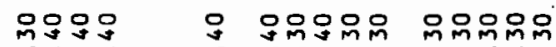

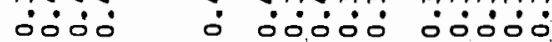

$\stackrel{\infty}{2}$

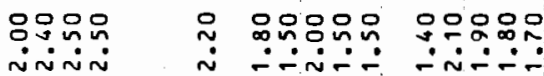

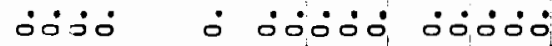



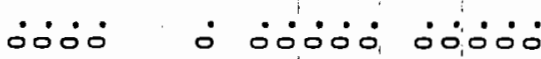

ํํำำ

๑0்

岌?

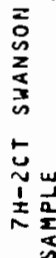

$n \infty m$

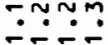

\section{ornn}

- 0.000.

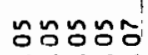

هंव்ं

a ononol

ลำำ

$\because \because \because \div-$

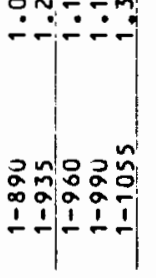

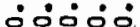

ลNก์

niminin:

유욤용

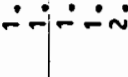

웅응ㅇㅇㅇ

向它宓

$\circ \circ \operatorname{lon}$

ㅇํㅇำ

هoं0ं

กิomm

$\because 0: \div 0$

$0=\tilde{x}=-$

ธีที่าก

-0ं0ं

0000

ำกำ

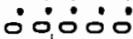

울웅요

¿0000

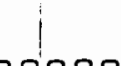

응ㅇㅇㅇㅇㅇㅇㅇ
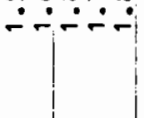

¿ó00:

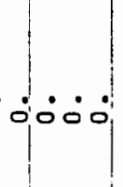

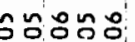

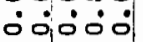

o, 00

ㅇำํํㅇ

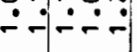

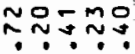

- $\dot{\sim} \dot{\sim}$

món

옹요음

- inimín

88ㅁㅇㅇ

minim-

88800

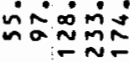

ำmiñ

N-1

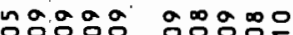

¿óó

ódió

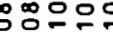

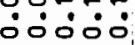

요용

웅응

章=星

용ำ

ऽंó

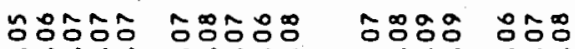

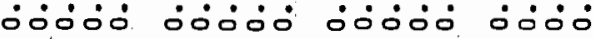

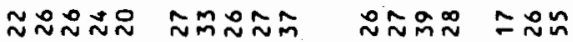

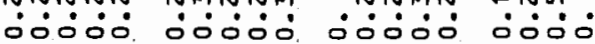

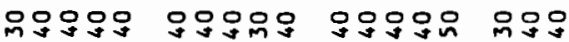

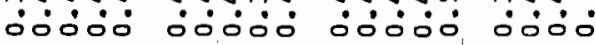

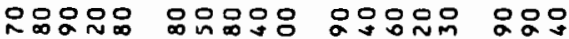

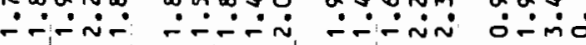

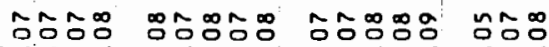

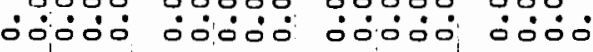

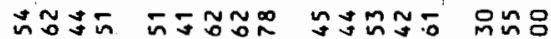

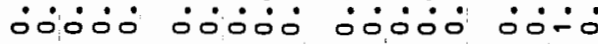

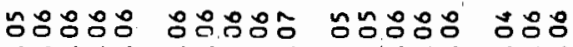

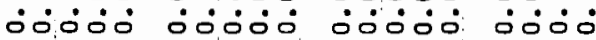

늠을은로

IIITI
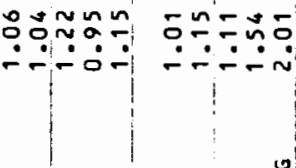

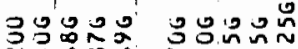

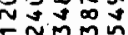

Iñming
-

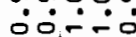

$a \div 2$

$\because \div \circ$

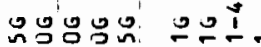

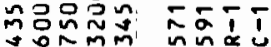

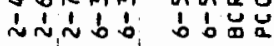




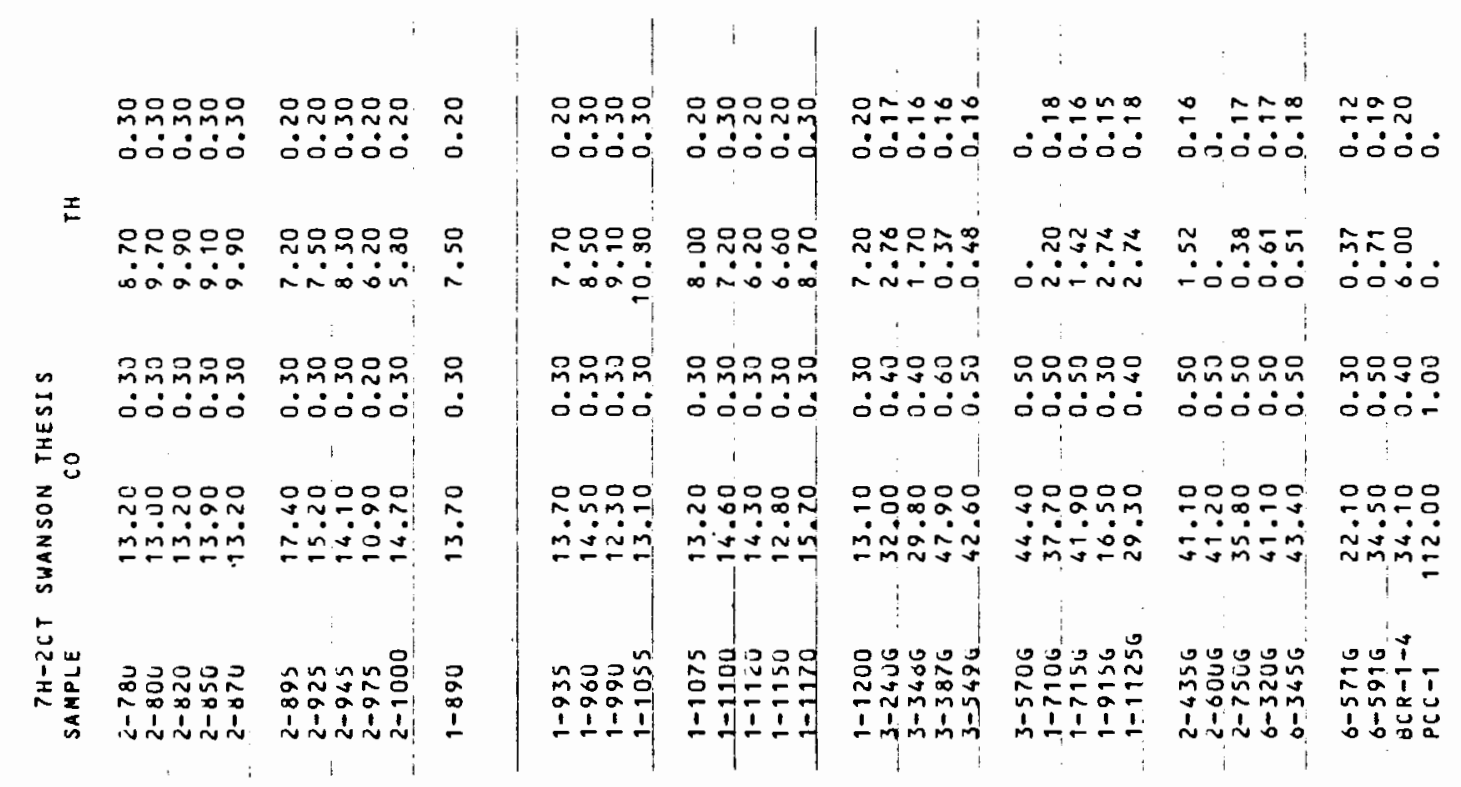




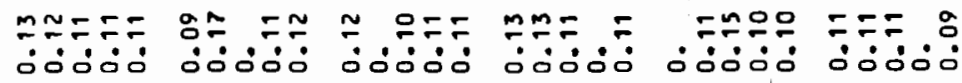

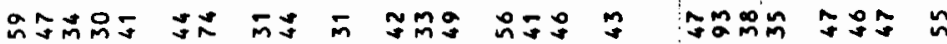

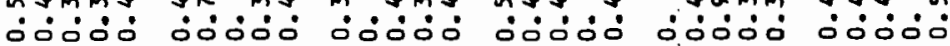

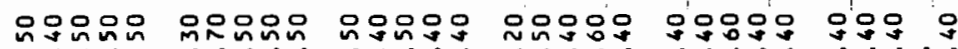

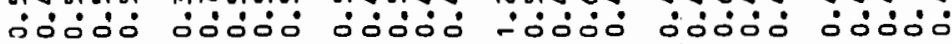

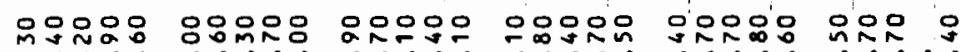

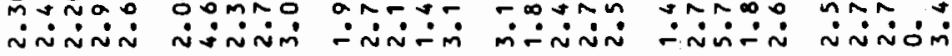

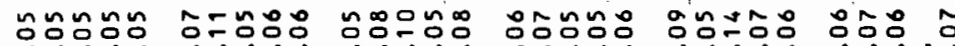

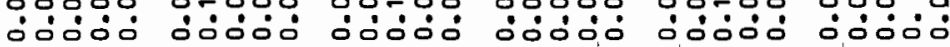

is

我品员

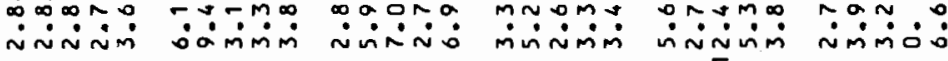

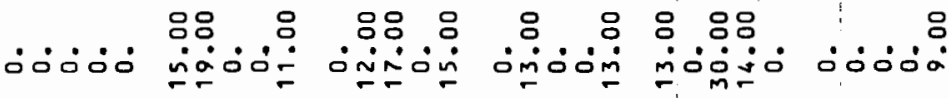
u

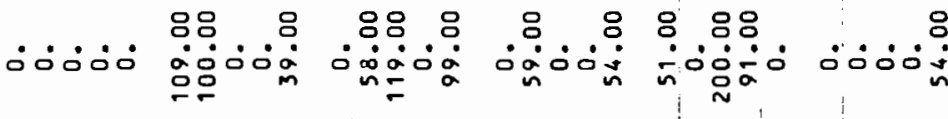

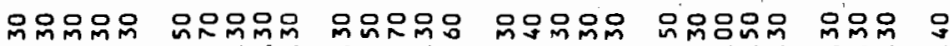

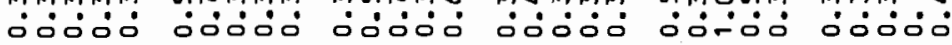

$\mathbf{3}$

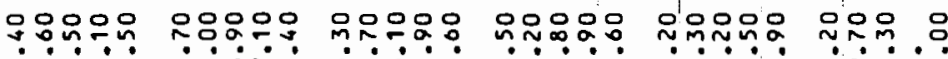
jivio

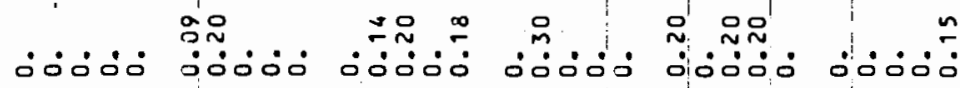

$*$

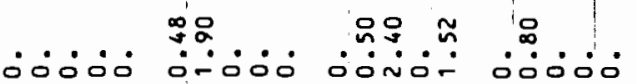

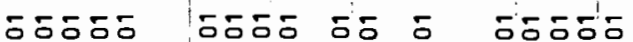

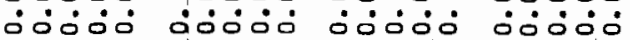

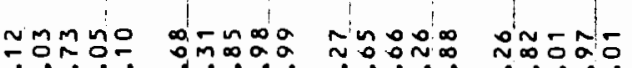

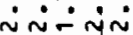
$\dot{\sim} \dot{0} \dot{\sim} 0$

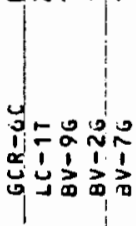

o. 0 $\sin n$

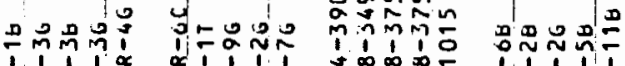

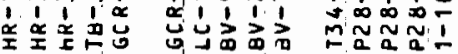

8.80 .5

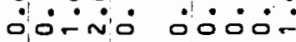

бо̄̄ó -0000 d0000

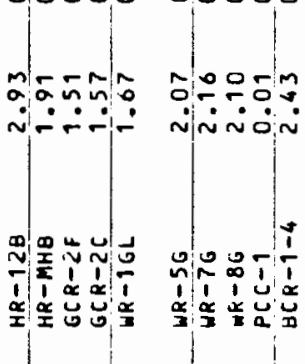




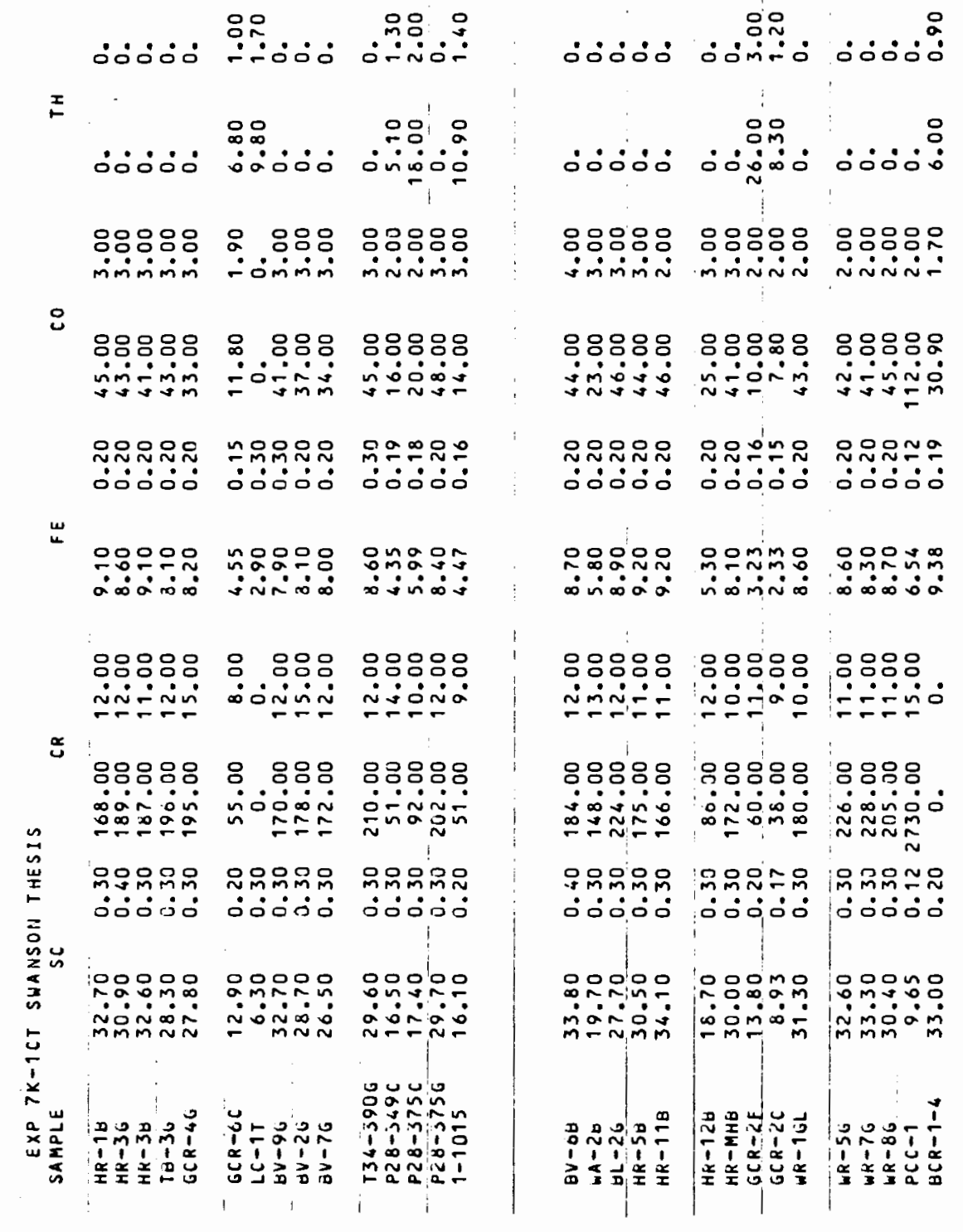




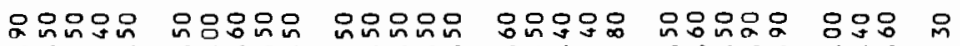

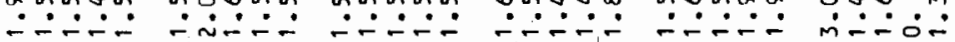

Шّ

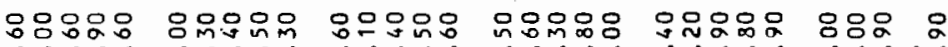
क메

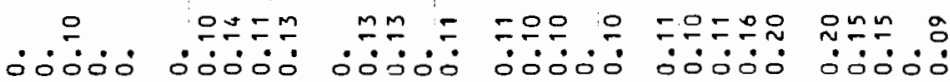

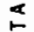

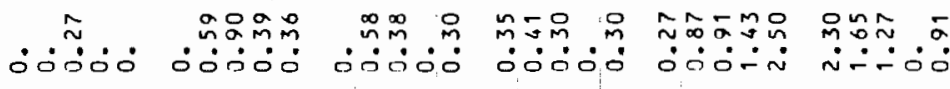

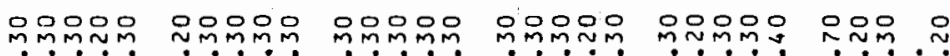

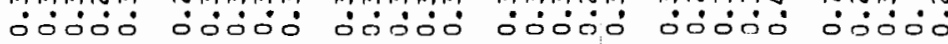

㭊

㐫

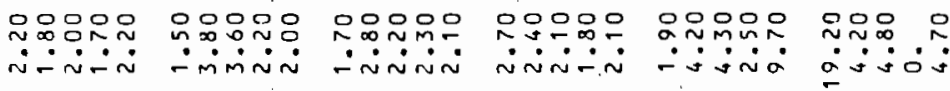

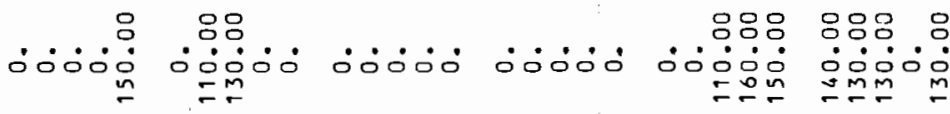

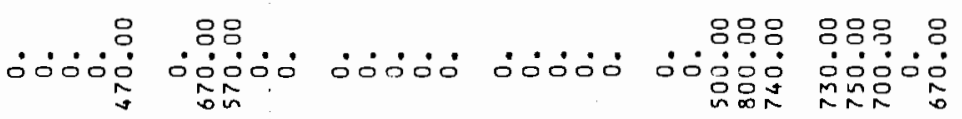

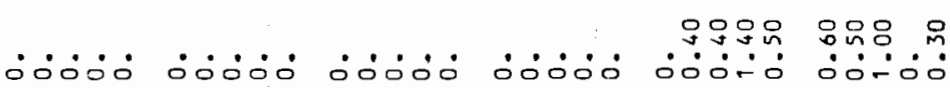
3

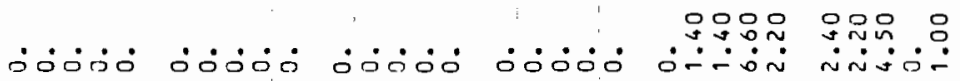

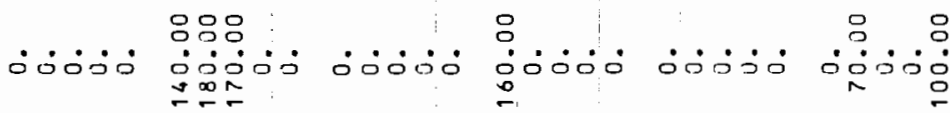
$\stackrel{x}{i n}$

$\stackrel{\substack{w \\ w \\ w}}{w}$

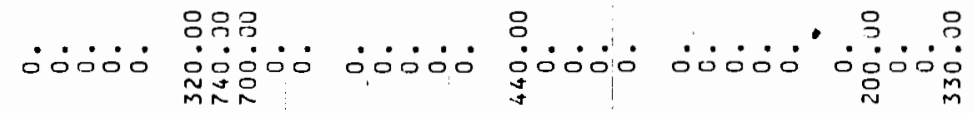

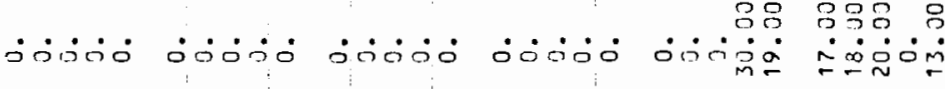
$\stackrel{\substack{x \\ x}}{n}$

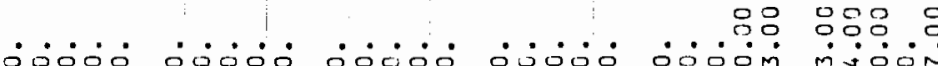

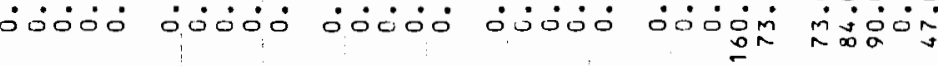

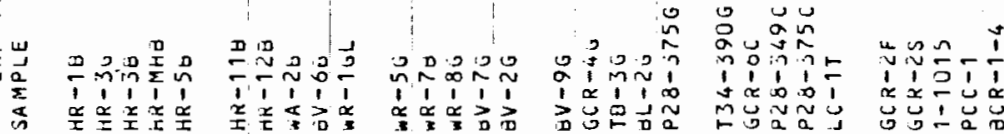




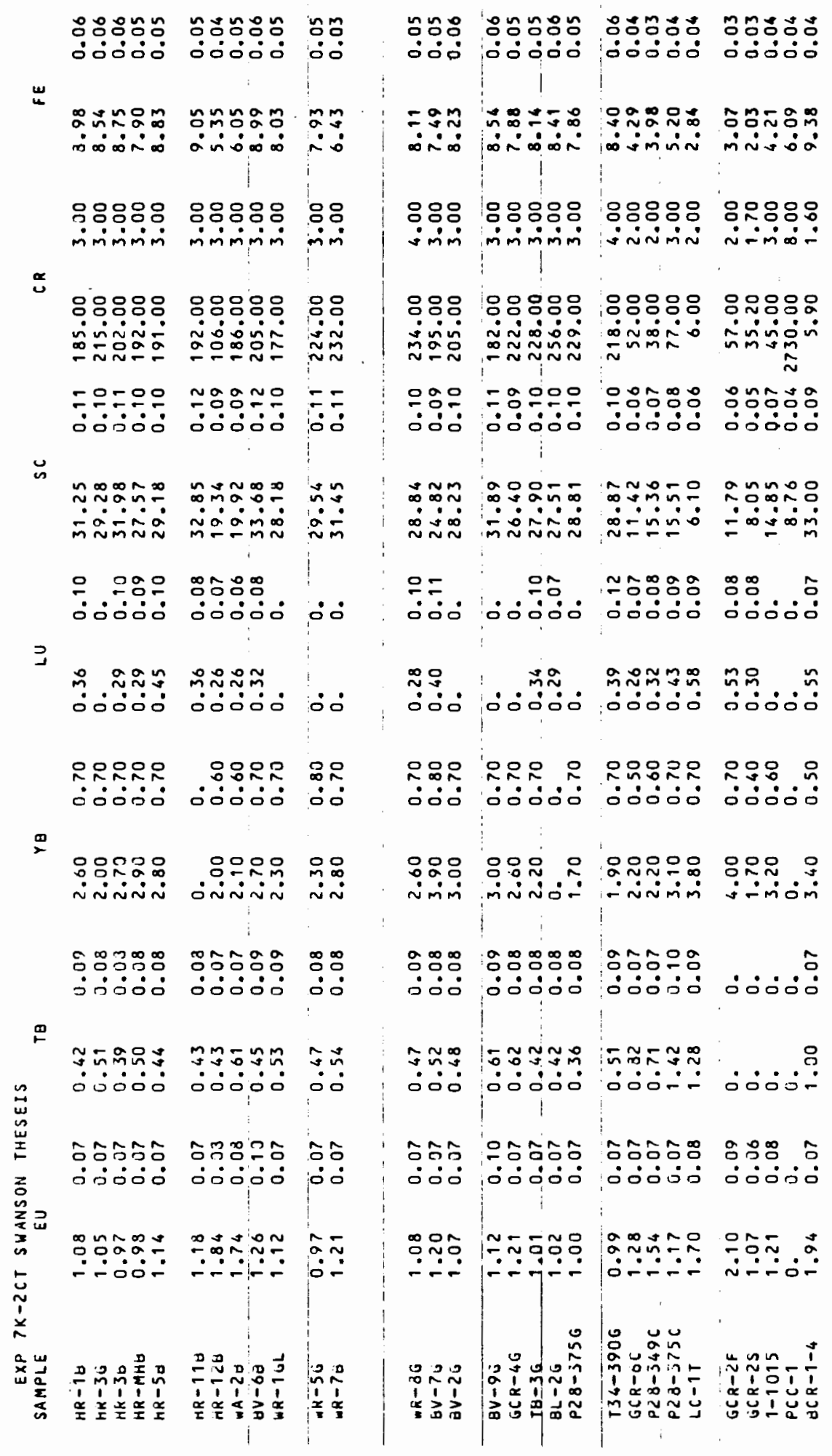




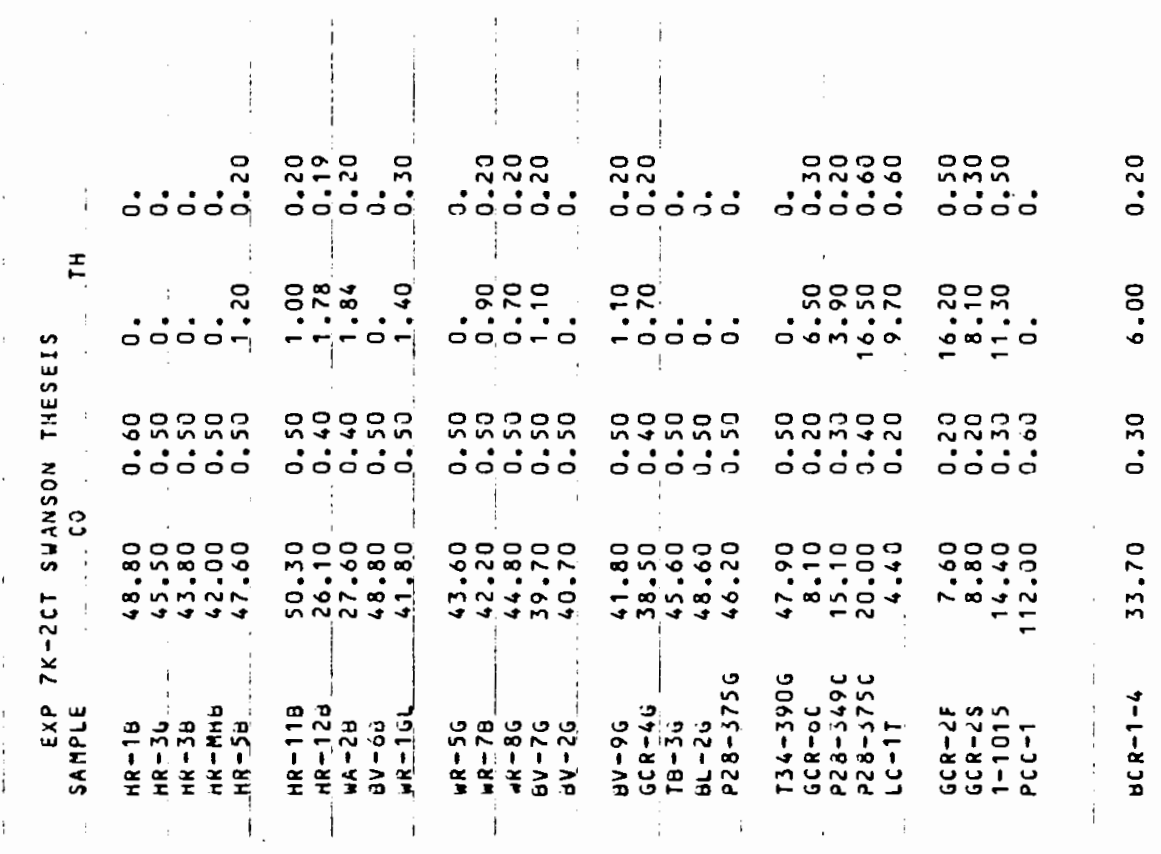


APPENDIX C

CROSS-SECTIONS OF WELL AREA

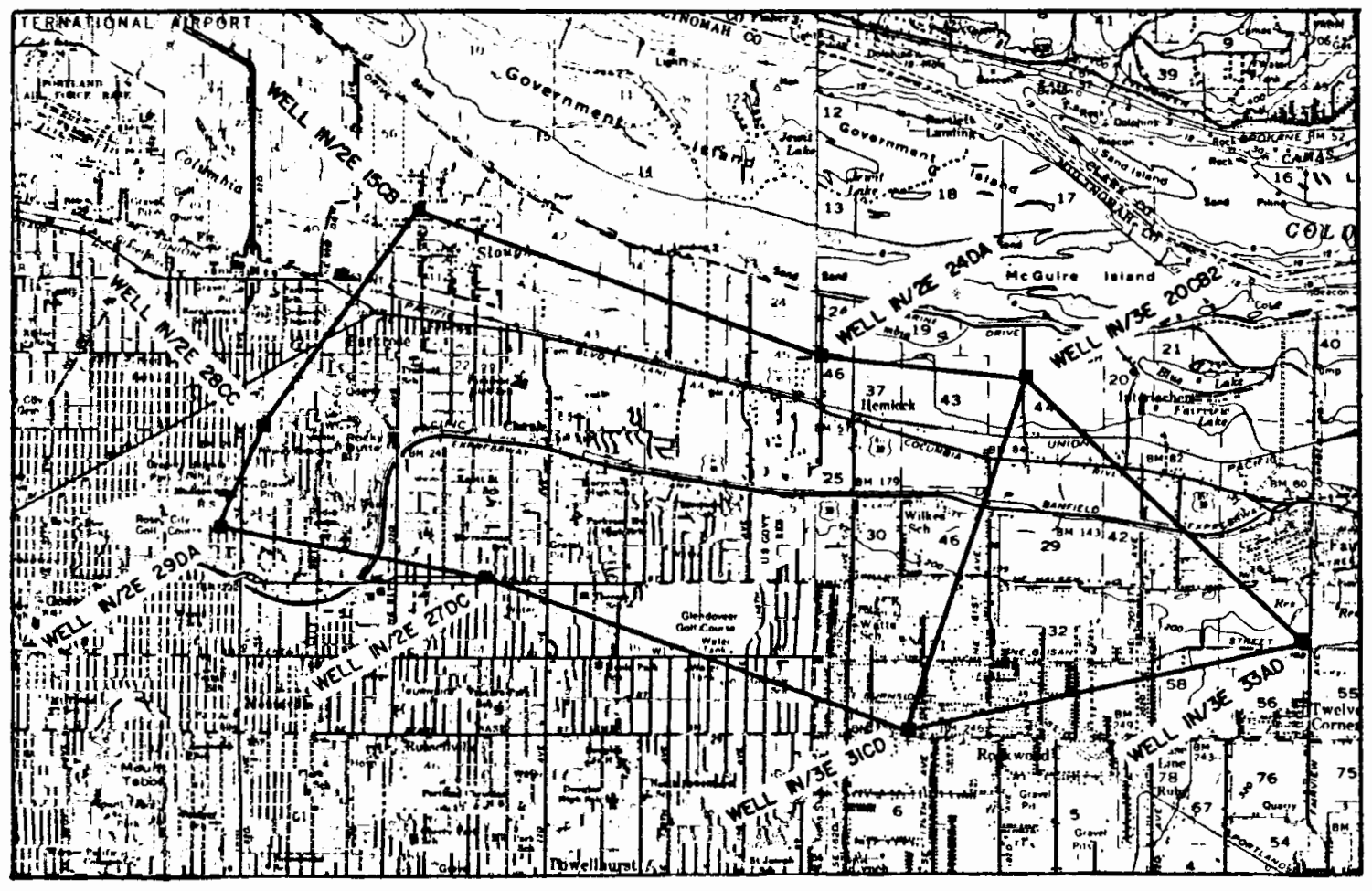

Figure 24. Location of cross-sections in Appendix C. 


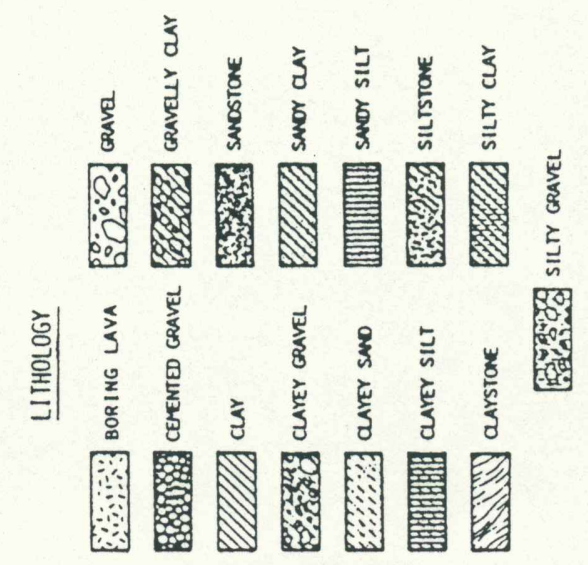

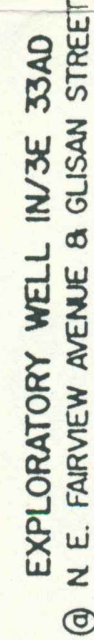
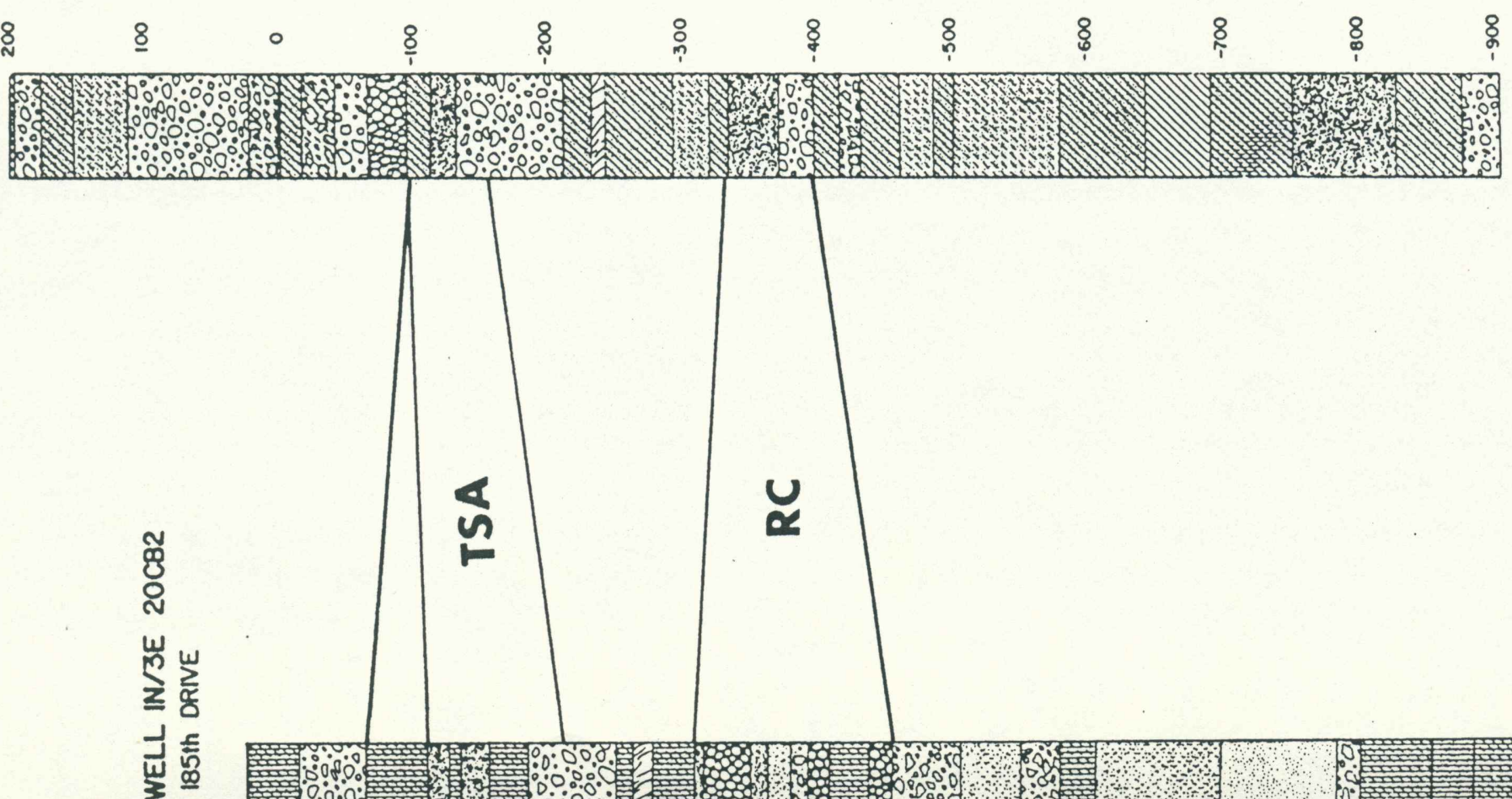

这

운

a

品

为

剀

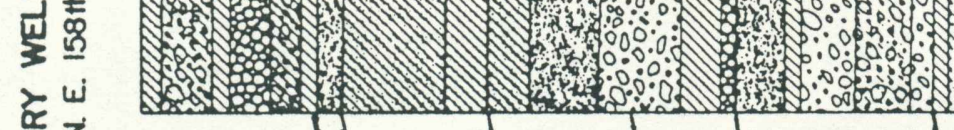

客る
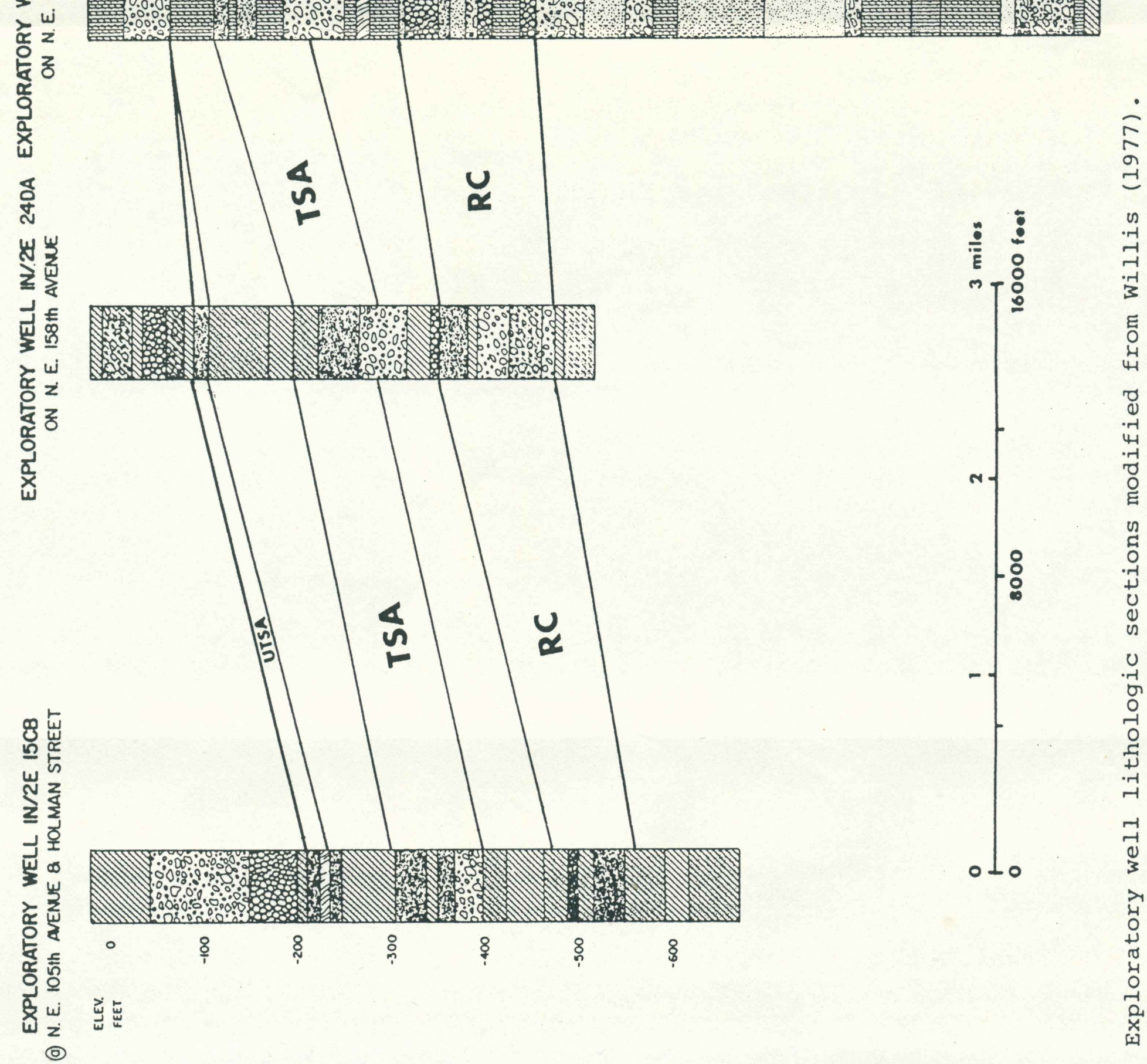
为

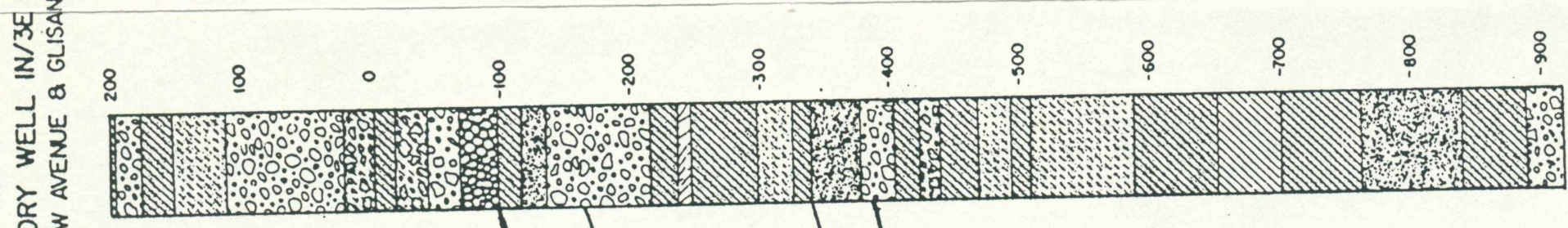

음

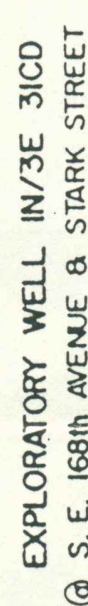

要

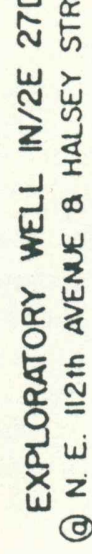

II

㟯

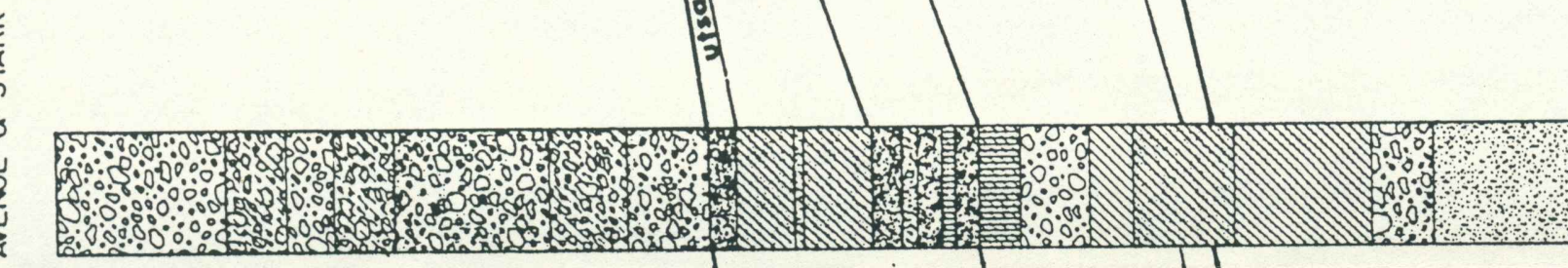

定
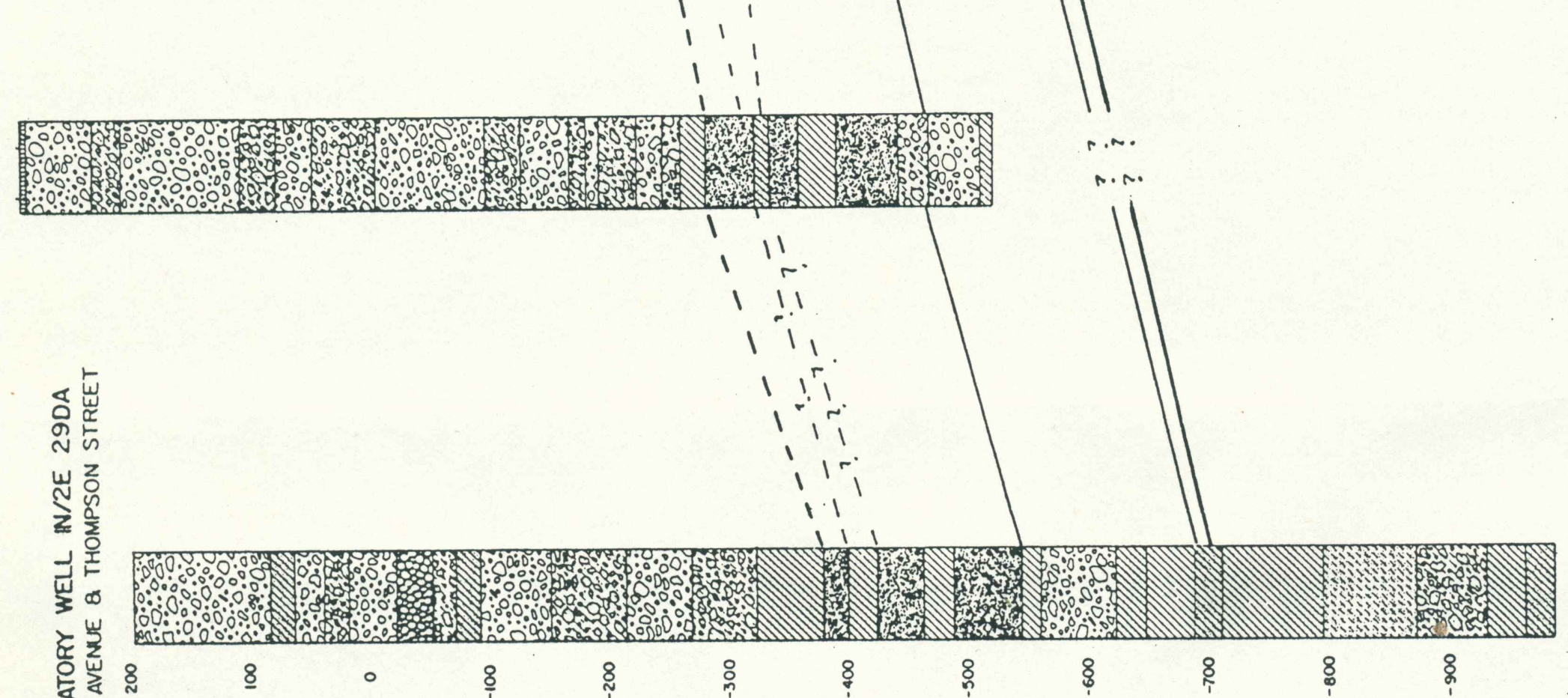

递 
